UNIVERSIDADE DE SÃO PAULO

FACULDADE DE FILOSOFIA, LETRAS E CIÊNCIAS HUMANAS

DEPARTAMENTO DE SOCIOLOGIA

PROGRAMA DE PÓS-GRADUAÇÃO EM SOCIOLOGIA

\title{
ACOPLAMENTO ESTRUTURAL, FECHAMENTO OPERACIONAL E PROCESSOS SOBRECOMUNICATIVOS NA TEORIA DOS SISTEMAS SOCIAIS DE NIKLAS LUHMANN
}

\section{Rômulo Figueira Neves}

Dissertação apresentada ao Programa de Pósgraduação em Sociologia do Departamento de Sociologia da Faculdade de Filosofia, Letras e Ciências Humanas da Universidade de São Paulo, como requisito parcial para a obtenção do título de Mestre em Sociologia

Orientador: Prof. Dr. Leopoldo Waizbort 


\section{AGRADECIMENTOS}

A Camila Serrano Giunchetti, pela inspiração e pelo apoio incondicional.

Ao professor Leopoldo Waizbort, pela orientação oportuna e paciente e pela introdução ao tema ainda no período da Graduação.

Aos professores Marcelo Neves, Celso Campilongo, Tércio Sampaio Ferraz Jr., Armin Mathis, Günther Teubner, Gottfried Stockinger, Dirck Baecker, Loet Leydesdorff, Darío Rodriguez, José Ossadón, Marcelo Arnold, Aldo Mascareño, Christian Morgner, Jakob Hundborg, Michael Terpstra, Levi Briant, Clarrissa E. B. Neves, Giancarlo Corsi, Elena Esposito, Gabriel Cohn, Cícero Araújo, Eduardo César Marques, Márcio Santos, Brasílio Sallum Jr, Ciro Marcondes Filho, Mário Eufrásio, José Jeremias de Oliveira Filho, Fernando Pinheiro, Willis Guerra Santiago, Clóvis de Barros, José María Blanco, Laurindo Minhoto e Maria Célia Paoli, pelos ensinamentos e pelas dicas.

E aos amigos e colegas Guilherme Leite Gonçalves, Orlando Villas Bôas Filho, Fabrício Neves, Leonardo Crochick, Marcos Toledo, Marcos Vinícius Marinho, Stefan Klein, Renato Godinho, Michele Markowitz, Clayton Perón Godoy, Adriana dos Santos, Demétrio Toledo, Olívia Perez, Rosileide Rosendo, Arlene Ricoldi, Edison Bertoncelo, Idenilza Miranda, Daniel Hirata, Francini Oliveira, Gustavo Cavalcanti, Patrícia Chueiri, Carolina Cadavid, João Conrado, João Paulo Freitas, Rodolfo Pinto, Leonita Horstmann, Harald Horstamnn e Jürgen Horstmann, pelo diálogo, pela ajuda com o alemão, pelos palpites e pelo intercâmbio.

Agradeço ainda a todos os funcionários da Secretaria de Pós-Graduação do Departamento de Sociologia da FFLCH-USP e da Biblioteca da FFLCH-USP.

Agradeço, finalmente, à Capes (Coordenadoria de Aperfeiçoamento de Pessoal de Nível Superior), que viabilizou este trabalho por meio de uma bolsa de estudos. 


\section{RESUMO}

A presente pesquisa, eminentemente bibliográfica, visa apresentar e analisar alguns dos conceitos fundamentais da teoria dos sistemas sociais de Niklas Luhmann, que propõe um novo paradigma no campo da Sociologia e tenta superar as teorias sociais clássicas. Sistemas sociais, na acepção luhmanniana, são sistemas autopoiéticos, fechados operacionalmente e auto-referentes, formados a partir de uma diferenciação com o ambiente externo. Essa diferenciação ocorre com o estabelecimento de uma marca, que possibilita ao sistema estabelecer o que lhe pertence e o que não lhe pertence. Sistemas sociais operam a partir de processos comunicativos, que adquirem sentido a partir da rede recursiva interna, cujo acesso ao ambiente é fechado. O ambiente é formado pelos outros sistemas existentes e por informações desorganizadas.

São apresentados os conceitos fundamentais da teoria para possibilitar a discussão de um aspecto específico: as relações inter-sistêmicas, principalmente por meio dos acoplamentos estruturais, mecanismo pelo qual um sistema utiliza, para colocar em funcionamento seus próprios elementos, as estruturas de um outro sistema, sem com isso, no entanto, confundir os limites entre eles. São relações inter-sistêmicas duradouras.

Finalmente, temporalidade, racionalidade e limites da observação dos sistemas sociais são aspectos utilizados para a elaboração e apresentação de um conceito ainda inédito, o de processo sobrecomunicativo. O conceito visa explicar como podem ocorrer eventos de influência externa em sistemas autopoiéticos sem o abandono das premissas da teoria, como o fechamento operacional e a auto-referência.

A estrutura formal da dissertação consiste em uma análise do funcionamento dos conceitos da teoria, observando a integração entre eles dentro do desenho geral, além de reflexões acerca de aspectos específicos dos conceitos que tratam da manutenção da integridade dos sistemas e de seu relacionamento com o ambiente e com os outros sistemas e da discussão do novo conceito apresentado, com a estruturação de seu funcionamento e a exemplificação de alguns de seus aspectos. Além disso, o trabalho contém também a tradução de um capítulo de um livro de Luhmann, que trata especificamente do conceito de acoplamento estrutural, para possibilitar o contato direto com o texto luhmanniano.

Palavras-chave: Sistemas sociais, acoplamento estrutural, fechamento operacional, processo comunicativo, processo sobrecomunicativo. 


\begin{abstract}
This thesis - based on bibliographic research - presents and analyzes some of the fundamental concepts of the Niklas Luhmann's social systems theory, which proposes a new paradigm for the Sociology and intends to surpass the classic social theories. Social systems, in the luhmannian sense, are autopoietic, operatively closed and self-referred systems, emerged from a differentiation from the environment. This differentiation occurs with the establishment of a mark, which permits the system to recognize what pertains or not to the system. Social systems operate with communications that acquire meaning through the inside recursive net, which access is closed to the environment. The environment is formed by other existing systems and by disorganized information.

The fundamental concepts of the theory are presented in order to introduce the debate about an specific aspect: the inter-systemic relationship, specially through structural coupling, the mechanism by which a system operates its own elements through the use of the structures of another system, meantime the limits between them are maintained. Structural couplings are long lasting inter-systemic relationships.

Finally, the temporality, rationality and limits of the observation of the social systems are used for the proposition of a new concept: overcommunication. The concept intends to explain how external influences can occur in autopoietic systems without the abandonment of the premises of the theory, such as the operational closure and the self-reference.

The formal structure of the thesis is as follows: an analysis of the functioning of the concepts of the theory, taking in account their integration into the general draw; reflections on specific aspects of the concepts which deal with the preservation of the integrity of the system and on the relationship of the system with the environment and with other systems and, finally, the presentation of the new concept, its structure, functioning and examples. A translation into Portuguese of a Luhmann's text about structural coupling is attached.
\end{abstract}

Keywords: Social systems, structural coupling, operative closure, communication, overcommunication. 


\section{ZUSAMMENFASSUNG}

Die gegenwärtige Untersuchung, hochrangig bibliographisch, beabsichtigt, einige der fundamentalen Begriffe der Theorie sozialer Systeme von Niklas Luhmann vorzustellen und zu analysieren, welcher ein neues Musterbeispiel im Bereich der Soziologie vorschlägt und versucht, die klassischen sozialen Theorien zu übertreffen. Soziale Systeme, in Luhmann's Sinne, sind autopoietische Systeme, operativlich geschlossen und selbstreferenziert, geformt $\mathrm{ab}$ einer Differenzierung mit der äusseren Umwelt. Diese Differenzierung tritt ein mit der Errichtung von einer Marke, welche dem System ermöglicht festzulegen, was ihm gehört und was ihm nicht gehört. Soziale Systeme operieren ab Kommunikationen, die Sinn bekommen ab dem internen rekursiven Netz, dessen Zugang zur Umwelt geschlossen ist. Die Umwelt ist gestaltet durch andere existierende Systeme und desorganizierte Informationen.

Die fundamentalen Begriffe der Theorie werden vorgestellt um die Diskussion einer seiner spezifischen Aspekte zu ermöglichen: Die intersystemischen Beziehungen, hauptsächlich mittels der strukturellen Kupplungen, ein Mechanismus durch den ein System, um seine eigenen Elemente in Funktion zu stellen, die Strukturen von einem anderen System benutzt, ohne das jedoch die Grenzen zwischen ihnen vermischt werden. Die strukturelle Kopplungen sind dauerhafte intersystemischen Beziehungen.

Letztendlich, Weltlichkeit, Vernüftigkeit und Beobachtungsbeschränkungen der sozialen Systeme sind Aspekte, die fuer die Erarbeitung und Darstellung eines noch neuen Begriffes, der Überkommunikation, benutzt werden. Der Begriff beabsichtigt zu erklären, wie die Ereignisse von externen Einflüssen auf den autopoietischen Systemen, ohne das die Voraussetzungen der Theorie aufgegeben werden, eintreten können, wie die operative Schließung und die Selbstreferenz.

Die formelle Struktur der Dissertation besteht aus einer Funktionsananalyse der Theoriebegriffe, unter Beachtung der Einbeziehung zwischen ihnen innerhalb des allgemeinen Bildes, ausser den Widerspielungen über die besonderen Aspekte der Begriffe die die Beibehaltung der Integrität der Systeme behandeln, seinem Verhältnis mit der Umwelt und mit anderen Systemen und der Diskussion über den vorgestellten neuen Begriff, mit der Struktur von seiner Funktionsweise und der Veranschaulichung von einigen seiner Aspekte. Ausserdem beinhaltet die Arbeit auch die Übersetzung zu Portuguesisch von einem Kapitel aus dem Buch von Luhmann, welches speziell den Begriff der strukturellen Kopplung behandelt, um so den direkten Kontakt mit Luhmann's Text zu ermöglichen.

Schlüsselwörter: soziale Systeme, strukturelle Kopplung, operative Schließung, Kommunikation, Überkommunikation. 
"Se queres sentir a felicidade de amar, esquece a tua alma. A alma é que estraga o amor. Só em Deus ela pode encontrar satisfação. Não noutra alma.

Só em Deus - ou fora do mundo. As almas são incomunicáveis. Deixa o teu corpo entender-se com outro corpo. Porque os corpos se entendem, mas as almas não."

Manuel Bandeira - A Arte de Amar

"Quero descansar Humildemente pensando na vida e nas mulheres que amei... Na vida inteira que podia ter sido e que não foi."

Manuel Bandeira - Antologia 


\section{ÍNDICE}

I - INTRODUÇÃO...............................................................................................................

I.1 Luhmann e a tradição sociológica ………………………………………………………………..... 14

II - OS SISTEMAS SOCIAIS......................................................................................17

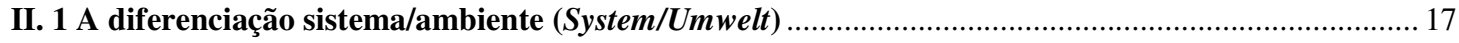

II. 2 Sistema operacionalmente fechado (operativ geschlossenes System) …………................................. 20

II. 3 Processos comunicativos (Kommunikationen - Kommunikationsprozesses) ........................................ 24

II. 4 Meios de Comunicação Simbolicamente Generalizados (symbolisch generalisierte

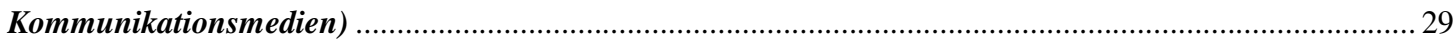

II. 5 Programas (Programme) ……………………………........................................................... 34

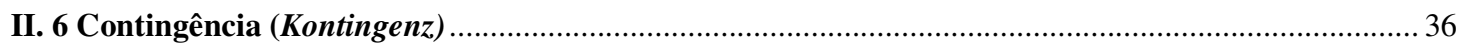

II. 7 Observação, auto-observação e observação de segunda ordem (Beobachtung, Selbstbeobachtung,

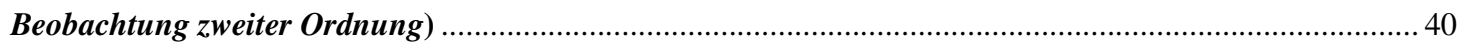

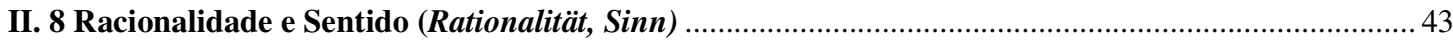

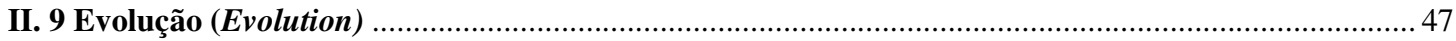

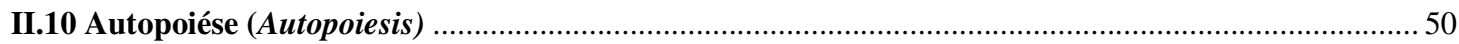

III - RELAÇÕES INTER-SISTÊMICAS _.........................................................53

III. 1 Acoplamento Estrutural (strukturelle Kopplung) ……………………………………………........ 53

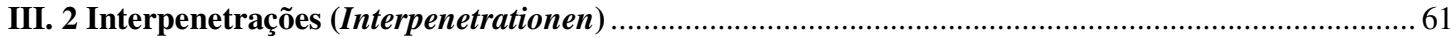

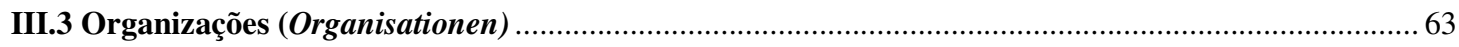

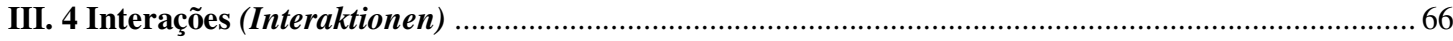

IV - INTERFERÊNCIAS EXTERNAS NO SISTEMA ...................................................68

IV.1 Alopoiése (Allopoiesis) - Sistemas de fechamento operacional incompleto............................................ 68

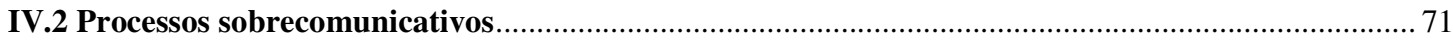

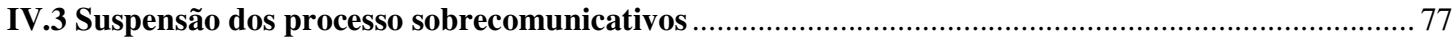

IV. 4 Processos sobrecomunicativos resultados de observação continuada …………………………........ 80

IV. 5 Processos sobrecomunicativos resultados de desvios de acoplamento ............................................. 90

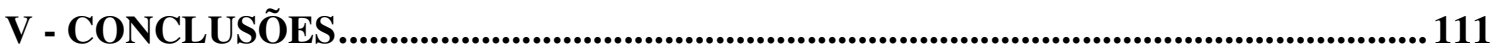

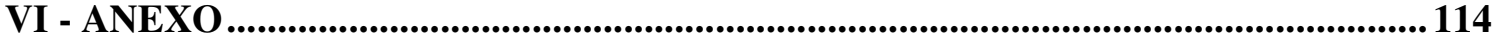

VII - BIBLIOGRAFIA ...................................................................................................... 145 


\section{I - INTRODUÇÃO}

Uma parte considerável da produção teórica dentro da Sociologia se baseou, até agora, em três autores que são os pilares da disciplina: Émile Durkheim, Karl Marx e Max Weber, que buscaram estabelecer teorias gerais da sociedade. Assim, muito do que se tem produzido na área são interpretações, análises e aplicações de elementos teóricos advindos dos trabalhos desses autores, os chamados clássicos, ou mesmo a reorganização de certos elementos ou a combinação de fatores de análise de uma e de outra das abordagens teóricas clássicas.

A realidade social, no entanto, sofreu transformações históricas, com o desaparecimento de certas formas de organização social e o aparecimento de outras, com o aparecimento de novos atores sociais e o desaparecimento de outros e com o surgimento de idéias que não faziam sentido nos momentos em que as teorias clássicas foram formuladas.

No campo da técnica, as mudanças ocorridas ao longo do último século fizeram desaparecer o mundo no qual aquelas teorias clássicas foram concebidas e brotar um mundo totalmente diferente, com o desenvolvimento de novas formas de locomoção, comunicação e interação. Além disso, a velocidade com que esse desenvolvimento ocorreu já é, em si, um fator a ser levado em consideração nesse processo de transformação da realidade social, na medida em que altera a forma de as pessoas lidarem com as transformações, tomando-as não mais como exceções, mas como regra contínua e constante.

Essas novas formas de organização dentro da sociedade, no entanto, continuaram a ser analisadas com o instrumental das teorias clássicas, com a utilização de alguns pressupostos teóricos que foram sendo reformados para dar conta dos acontecimentos sociais contemporâneos. Um conceito clássico original, muitas vezes, sofre tantas deformações para abarcar essas novas experiências sociais que chega, em algumas análises, a se afastar tanto do significado original que se torna irreconhecível. Dessa forma, um mesmo conceito acaba sendo utilizado para fazer referência a situações muito diferentes entre si.

Os conceitos de classe, acumulação primitiva de capital e mais-valia, por exemplo, perderam precisão e mesmo a aplicabilidade como descrição indiscutível de alguns fenômenos sociais contemporâneos comumente associados àquelas idéias, devido ao crescimento da complexidade da sociedade. Fronteiras que eram mais ou menos claras nas observações de um século atrás já não fazem mais sentido e esses conceitos já não explicam 
com perfeição os fenômenos da sociedade contemporânea. O Estado, a organização religiosa e outras organizações sociais já não funcionam da mesma maneira e não estão mais hierarquizados como estavam há um século.

As poucas tentativas teóricas que buscaram, contemporaneamente, abranger a análise de toda a sociedade, como o fizeram as teorias clássicas, limitaram sua eficácia ao definir apenas um ponto da sociedade ou das relações sociais como o pressuposto inicial de todas as análises subseqüentes em qualquer um dos campos da sociedade. Não há mais, no entanto, um ordenamento geral ao qual os ordenamentos particulares devam respeito ou extraiam sua coerência. Dessa forma não podemos mais, como fez Michael Foucault, com o poder, e Jürgen Habermas, com o agir comunicativo, tomar apenas um elemento como o centro de dotação de sentido em todos os campos da análise sociológica.

Esses instrumentos, apesar da pretensão de abrangência, mostram-se muito eficazes na análise de certos segmentos da sociedade, mas perdem sua aplicabilidade em outros e, no mesmo sentido das teorias clássicas, têm que ter os seus conceitos afrouxados para dar conta da análise de formas de relação social e acontecimentos sociais de outros campos para os quais não são eficazes como instrumento de análise. Isso ocorre porque a sociedade contemporânea tornou-se policêntrica, isto é, sem um ponto único de onde derivam todos os sentidos das relações sociais. Há, ao contrário disso, uma profusão de campos autônomos, onde os mais variados tipos de relações se desenvolvem em sua plenitude, sem a necessidade de legitimação externa.

Obviamente, há também contribuições contemporâneas originais, que deram origem a conceitos teóricos que não estavam presentes nas teorias clássicas. Em sua grande maioria, no entanto, essas contribuições não são teorias que visam a análise de toda a sociedade e perdem abrangência ao fragmentar a análise em diversas disciplinas empíricas, limitando-se a realizar estudos isolados, não conseguindo, por isso, observar a complexidade como um todo.

É a partir deste diagnóstico da impossibilidade de descrição precisa e ao mesmo tempo abrangente das relações sociais modernas, tanto das teorias clássicas quanto da sociologia contemporânea, que a teoria dos sistemas sociais, desenvolvida pelo sociólogo alemão Niklas Luhmann (1927-1998), adquire importância e se apresenta como uma possibilidade de avanço da análise da sociedade. 
A teoria dos sistemas sociais é uma tentativa de ultrapassar os pressupostos e conceitos clássicos e criar um novo paradigma, com novos conceitos, para explicar e analisar a sociedade contemporânea. É uma tentativa de observar a modernidade, aqui incluída a pósmodernidade, com abertura suficiente para explicar inclusive a extrema velocidade das transformações sociais, sem, no entanto, preocupar-se com a previsão a priori dessas mesmas transformações.

Segundo Luhmann, as teorias clássicas já não conseguem abarcar os fenômenos contemporâneos com eficácia porque se detêm nas relações sujeito-objeto, mas a sociedade contemporânea já não mais reconhece apenas dois lugares tão claros e determinados para os eventos sociais. Em outros casos, baseiam-se em abordagens deterministas ou em pressupostos que levam em consideração a integração social, mesmo quando as organizações sociais não são mais determinadas a partir da busca do consenso, de uma localização geográfica específica ou da proximidade física.

Outra característica das teorias clássicas, que Luhmann critica como forma ultrapassada de análise social, é o papel central do indivíduo na análise da sociedade. Dentro da teoria dos sistemas sociais, o indivíduo é um elemento que está fora do sistema social e atua apenas como elemento acoplado, provocando, dessa maneira, apenas ruído ou irritação ao funcionamento do sistema.

A pretensa objetividade das explicações científicas também é um elemento que Luhmann evita na teoria dos sistemas sociais, ainda que esse tipo de abordagem apareça em outras teorias sistêmicas. Outro ponto que não faz parte da teoria são as determinações causais, pois um de seus pressupostos é o de que os eventos sociais são contingentes. Tanto a ciência como as determinações causais são tratadas pela teoria dos sistemas sociais como elementos observáveis da sociedade; no caso da ciência, um sistema da sociedade, ela está sujeita às próprias premissas descritas na teoria e, no das determinações causais, são tomadas como um medium utilizado para compor o discurso de alguns sistemas, portanto uma forma de estruturação dos sentidos e processos comunicativos não da sociedade ampla, mas apenas dos sistemas que o utilizam.

A proposição de Luhmann para ultrapassar os problemas de acuidade dos instrumentos da teoria sociológica para a análise da sociedade contemporânea está baseada em divisões simultâneas da totalidade da sociedade em fragmentos isolados com lógica interna própria, os 
sistemas sociais (soziale Systeme), e seus respectivos ambientes (Umwelten), formados por todos os outros sistemas existentes e a totalidade de eventos desorganizados da sociedade.

Essa forma de observar as relações sociais é, segundo Luhmann, a ideal para captar a complexidade existente na sociedade contemporânea, pois, por internalizar em seus próprios conceitos essa complexidade, é capaz de analisá-la. A natureza policêntrica da sociedade se expressa na teoria mediante a assunção da existência de vários locus, de onde a análise pode partir, sem que isso signifique a redução da complexidade de cada campo, sistema na acepção luhmanniana, aos elementos de sentido de outro. É certo que essas análises de um local de observação, ou um sistema, sobre outro necessitam de estruturas específicas, que dêem sentido ao discurso descritivo, mas mesmo isso aparece na teoria, com o conceito de observação de segunda ordem. Outra aspecto que diferencia a teoria dos sistemas sociais dos outros discursos teóricos dentro da sociologia é que os paradoxos, de que outras teorias procuram se afastar, foram introduzidos como fatores de análise.

Luhmann começou a desenvolver a teoria dos sistemas sociais com a utilização de conceitos nascidos em outros campos do conhecimento, como a cibernética, principalmente os conceitos de sistema auto-organizativo e ambiente presentes na obra de Heinz von Foerster, a neurobiologia, com o conceito de autopoiése presente na obra de Humberto Maturana e Francisco Varela e a lógica, com o conceito de forma, presente na obra de George Spencer Brown.

No momento em que Luhmann se apropriou desses conceitos, no entanto, ele os reformulou a fim de esclarecer os moldes em que funcionariam dentro da teoria social. Dessa forma, na teoria dos sistemas sociais, as diferenças e as fronteiras entre os campos do social, do biológico e da máquina são claros e precisos.

\footnotetext{
${ }^{1}$ Para mais detalhes ver: Foerster, H. von. On Self-organizing Systems and their Environment. Nova York, Pergamon, 1960; Gunther, G. "Cybernetic Ontology and Transjunctional Operations”. In: Yovits, M., Jacobi G. \& Goldstein G. (Org.) Self Organizing Systems. Washington D. C., Spartan Books, 1962; Spencer-Brown, G. Laws of form. Londres, Allen \& Unwin, 1969; Varela, F. Principles of biological autonomy, Nova York, Elsevier, 1979 e Maturana, H. e Varela, F. Autopoiesis and cognition, Boston, D. Reidel, 1979. Todos esses autores estavam envolvidos, na década de 1960, com a pesquisa cibernética e com o desenvolvimento da teoria dos sistemas auto-organizativos, contribuindo cada um com um ou mais conceitos. Foram desenvolvidos modelos de explicação para os sistemas recursivos e autopoiéticos. A teoria dos sistemas sociais de Luhmann é tributária mais desta mudança de perspectiva, que possibilitou o desenvolvimento dos conceitos de sistemas sociais fechados operacionalmente, mas abertos cognitivamente, do que da tradição sociológica.
} 
Assim, dentro da teoria, são reconhecidos outros tipos de sistemas além dos sistemas sociais, como as máquinas, os sistemas psíquicos e os sistemas biológicos. Cada um deles, porém, tem um elemento de funcionamento interno que os diferencia. As máquinas não constituem sistemas vivos, são considerados sistemas triviais, ou seja, suas formas de funcionamento e elementos internos são comandos e funções previamente estabelecidos. No caso dos sistemas biológicos, os elementos internos de funcionamento são formas de funcionamento dos órgãos, tecidos e células dos seres vivos, e, no caso dos sistemas psíquicos, os elementos de funcionamento interno são os pensamentos.

Dentre os diversos tipos de sistemas que a teoria luhmanniana reconhece, a análise está interessada especificamente nos sistemas que têm como elemento de funcionamento processos comunicativos (Kommunikationen) ${ }^{2}$, ou seja, os sistemas sociais. Em vários momentos, os sistemas psíquicos também são levados em consideração na análise dos sistemas sociais, na medida que desenvolvem com estes uma forma de relacionamento especial, o acoplamento estrutural (strukturelle Kopplung), e utilizam, assim como os sistemas sociais, o conceito de sentido (Sinn) como elemento interno, além de constituir fator de perturbação para os sistemas sociais.

Luhmann propõe, na teoria dos sistemas sociais, a análise da sociedade como um sistema social amplo, dentro do qual todos os outros sistemas se agrupam sem que, no entanto, haja coordenação entre os diversos sistemas. Cada um se desenvolve e funciona com seus próprios processos comunicativos internos. Assim, o que vale dentro do funcionamento do sistema social economia (Wirtschaft), por exemplo, não vale necessariamente dentro do sistema religião (Religion). A partir deste tipo de proposição podemos verificar o funcionamento de cada âmbito da sociedade de forma independente, sem determinações $a$ priori de quais elementos conferem sentido naquele âmbito. Esse tipo de análise procura mapear os elementos que o ordenam e descrever seu modo de operar, através da observação (Beobachtung). Cada área organizada em um sistema apresentará, assim, seus próprios processos comunicativos, o meio de comunicação simbolicamente generalizado, o traço característico daquele sistema.

\footnotetext{
${ }^{2}$ Traduzimos o termo Kommunikationen por "processos comunicativos" para evitar a confusão com o termo comunicação, largamente utilizado em várias teorias sociais. Além disso, como veremos adiante, Kommunikationen são constituídas, na teoria dos Sistemas Sociais, por três partes distintas, ainda que muitas vezes simultâneas.
} 
A teoria dos sistemas sociais tem a ambição de ser uma teoria abrangente e de dar conta da análise das diversas formas de organização da sociedade complexa. Seus instrumentos de análise não são, no entanto, conceitos significativos fechados, mas modelos abstratos que descrevem as fronteiras dos sistemas e a forma pela qual os processos comunicativos internos aos sistemas sociais operam. Assim, não existe um processo comunicativo a priori que funcione em todos os sistemas sociais, mas uma forma de organização e de delimitação dos sistemas que se dá a conhecer apenas com a observação de cada um deles.

O processo de delimitação de um sistema social implica aquela divisão essencial do todo em apenas duas partes: um sistema e seu ambiente. Esse processo busca a redução, dentro do sistema, da complexidade do mundo, pois limita a quantidade de elementos internos do sistema.

Os sistemas se formam, então, para organizar, segundo regras internas, uma parcela da desordenada e complexa sociedade, o espaço desorganizado (unmarked space). Cada divisão da sociedade em um espaço organizado internamente e um ambiente externo - isto é, a delimitação de um sistema social - é um processo dinâmico, que se completa num intervalo temporal, e que se superpõe, simultaneamente, a outras divisões possíveis e reais de outros sistemas e ambientes na sociedade. A cada observação parcial da sociedade podemos descrever uma dessas divisões.

Quando, dentro da teoria dos sistemas sociais, falamos de um sistema, de suas características e dos processos comunicativos que podemos observar, estamos falando a partir de um outro sistema, no nosso caso do discurso científico, que observa aquela divisão.

Dessa forma, quando descrevemos um sistema, suas características e seus processos comunicativos, estamos realizando uma descrição e uma observação a partir do sistema ciência (Wissenschaft) e do discurso científico, que tem seus próprios processos comunicativos internos. A teoria dos sistemas sociais se insere, então, ela mesma, dentro das possibilidades de análise e descrição da realidade social que a teoria propõe.

As diversas distinções superpostas são a expressão da complexidade da sociedade contemporânea. A partir da observação dos sistemas em funcionamento, um observador pode começar a perceber em quais situações essa ou aquela divisão está sendo realizada, em quais 
momentos um sistema ou outro está operando. As seleções dos processos comunicativos em operação a cada momento são a dinâmica temporal da complexidade.

O próprio desenvolvimento dos sistemas é um processo temporal, resultado do encadeamento de decisões e comunicações, que vão formando no tempo novas premissas de distinções, novos processos de diferenciação, reduzindo a complexidade do ambiente ao mesmo tempo em que aumentam a complexidade interna dos sistemas sociais.

O desenho da teoria dos sistemas sociais foi apresentado de forma mais completa basicamente em duas obras de Luhmann, Soziale Systeme (Sistemas Sociais), de 1984 e Die Gesellschaft der Gesellschaft (A sociedade da sociedade), de 1998. O esboço da teoria, no entanto, foi sendo elaborado desde o início de sua carreira em Bielefeld, em 1966, e muitos dos seus livros com análises de sistemas sociais específicos, como a religião (Die Religion der Gesellschaft) e a política (Die Politik der Gesellschaft) entre outros, apresentam fragmentos do desenho da teoria, que ajudam a compreendê-la. A teoria dos sistemas sociais, porém, não é um projeto fechado e acabado, pois ainda há abertura para novas incursões e alternativas para ilustrar e desenvolver alguns dos conceitos mais intricados e abstratos.

Neste sentido, este trabalho tenta apresentar os conceitos principais da obra de Luhmann, ao mesmo tempo em que procura discutir crítica e construtivamente o funcionamento de alguns de seus principais elementos: o funcionamento simultâneo do fechamento operacional dos sistemas sociais, ou seja, a autonomia de cada um dos sistemas frente aos elementos do ambiente, e o mecanismo de acoplamento estrutural, que é a capacidade dos sistemas de utilizarem elementos de outros sistemas para possibilitar suas próprias operações internas, sem, no entanto, precisar internalizar os processos comunicativos do outro sistema. 


\section{I.1 - Luhmann e a tradição sociológica}

O diálogo de Luhmann com os teóricos das ciências sociais sempre foi pautado, como vimos, pela relação com o desenvolvimento teórico de outras áreas do conhecimento, nas quais eram elaborados conceitos úteis para a formulação de uma teoria social mais apropriada, segundo o sociólogo alemão, à análise da modernidade e da complexidade das novas formas de relações sociais, na tentativa de superar os déficits da capacidade da tradição sociológica na explicação da sociedade, tal como observados por Luhmann. Isto não significa que ele não tenha tido conhecimento e domínio das teorias clássicas, mas sim que a elaboração da teoria dos sistemas sociais não pode ser tributada a um diálogo específico com este ou aquele autor, apesar de ser possível realizar uma análise genética e identificar algumas aproximações com diversos deles.

Assim, podemos traçar paralelos de alguns conceitos weberianos com a teoria dos sistemas sociais, como as esferas sociais e os meios específicos peculiares ao Estado ${ }^{3}$, por exemplo, mas os conceitos não são análogos e, além disso, essas similaridades não constituem nem o ponto de partida nem a base da teoria dos sistemas sociais. Também é certo, neste sentido, que não se organizam da mesma forma, dentro das respectivas teorias, os conceitos luhmannianos e a conceituação weberiana de finalidades e de interação, apesar de carregarem carga semântica próxima, a saber: objetivos finais de determinada comunicação ou ação e relação social entre duas pessoas ou indivíduos, respectivamente.

Com um pouco mais de proximidade podemos citar a obra de Talcott Parsons, a que muitos analistas filiam indiscriminadamente a obra de Luhmann, condição negada pelo próprio sociólogo alemão. De fato, os dois trabalharam juntos em Harvard no início dos anos 1960 e pode-se atribuir a este diálogo uma parte do desenvolvimento da teoria luhmanniana, assim como se pode verificar a utilização de algumas elaborações teóricas advindas do aparato parsoniano, como o conceito de interpenetrações. Luhmann, no entanto, faz questão de apontar a diferença fundamental entre sua teoria e o modelo de Parsons: a autonomia dos sistemas e a autopoiése, sem a qual todo o arcabouço teórico da teoria dos sistemas sociais não poderia ser elaborado. Com os conceitos desenvolvidos na área da cibernética, Luhmann

\footnotetext{
${ }^{3}$ Para mais detalhes ver: Weber, M. Economia e Sociedade, Brasília, UnB, 2000, pp. 19 e seguintes e Weber, M. Ensaios de Sociologia, Rio de Janeiro, Zahar, 1979, pp. 379 e seguintes.
} 
pode elaborar a idéia de fechamento operacional. Para Parsons, o sistema era aberto, como na teoria geral dos sistemas ${ }^{4}$, o que, para Luhmann, excluía toda possibilidade de serem estabelecidos limites entre os sistemas, inviabilizando assim a formação de identidades, de desenvolvimento autônomo, de aprendizado e de evolução. Além disso, e em conseqüência desse primeiro aspecto, existia, no modelo parsoniano, a idéia de integração e de consenso normativo, que neutralizava a dupla contingência dos agentes, e existia também, em última análise, uma hierarquia entre os sistemas. ${ }^{5}$

É certo que já aparecem na teoria funcionalista de Parsons os conceitos de contingência, complexidade, significado, especialização e símbolos próprios de cada sistema, mas Luhmann utiliza aqueles conceitos da cibernética para prover uma releitura dos termos parsonianos e reenquadrá-los no novo arcabouço teórico que criou, baseado no fechamento operacional, com abertura cognitiva, que reconhece o dissenso e a evolução autônoma dos sistemas.

Por fim, poderíamos citar o diálogo entre Luhmann e Habermas, mas neste caso não poderiam ser propostas aproximações ou filiações. O debate entre os dois alemães teve início nos anos 1970 e foi publicado em um livro conjunto ${ }^{6}$, onde são apresentados os argumentos e contra-argumentos de ambos para suas respectivas críticas. De um lado Habermas avaliava como conservadora a teoria luhmanniana, de outro, Luhmann atacava a centralidade da ação do indivíduo na teoria de Habermas. No início da década de 1980, ambos publicaram suas respectivas obras fundamentais ${ }^{7}$, seguramente com insights adquiridos no debate, mas sem incorporar posições centrais um do outro.

De qualquer forma, estudos comparativos e da gênese da teoria não são o escopo principal do presente trabalho e constituiriam material para uma pesquisa específica, a fim de não serem produzidas conclusões superficiais dando conta de identidades frágeis, filiações

\footnotetext{
${ }^{4}$ Para mais detalhes ver: Bertalanffy, L.von. Teoria Geral dos Sistemas. Petrópolis, Vozes, 1997.

${ }^{5}$ Para mais detalhes ver: Parsons, T. Sociological Theory and Modern Society. Nova York, Free Press, 1967; Parsons, T. The System of Modern Societies. Nova Jersey, Prentice Hall, 1971; Parsons, T. The Structure of Social Action. Nova York, Free Press, 1968 e Parsons, T. Social Systems and the Evolution of Action Theory. Nova York, Free Press, 1977.

6 Habermas, J. \& Luhmann, N. Theorie der Gesellschaft oder Sozialtechnologie - Was leistet die Systemforschung? Frankfurt a.M., Suhrkamp, 1971.

${ }^{7}$ Em 1981, Habermas publica Theorie des kommunikativen Handelns (Teoria da Ação Comunicativa) e, em 1984, Luhmann publica Soziale Systeme (Sistemas Sociais). Apenas em 1998, no entanto, Luhmann publica o
} 
indevidas ou mesmo ignorando parcelas importantes de gênese da teoria. A premissa desta dissertação, fundamentada na própria descrição de Luhmann e na análise da tradição sociológica, é a de que a teoria dos sistemas sociais é constituída de um arranjo original de alguns conceitos pré-existentes e do desenvolvimento de novos conceitos, o que a torna uma teoria autônoma e inédita, ainda que possamos enquadrá-la como tributária da teoria geral dos sistemas e do funcionalismo parsoniano de um lado e do desenvolvimento das pesquisas da cibernética, de outro.

No próximo capítulo, apresentamos os conceitos fundamentais da teoria, obedecendo uma estratégia de entrada a partir dos mais gerais para os mais específicos, a fim de expor da forma mais clara possível o arcabouço teórico-sistêmico.

que deve ser considerado a finalização do desenvolvimento da teoria dos sistemas sociais: Die Gesellschaft der Gesellschaft (A Sociedade da Sociedade). 


\section{II - OS SISTEMAS SOCIAIS}

\section{1 - A diferenciação sistema/ambiente (System/Umwelt)}

A multiplicidade das operações sociais possíveis na sociedade estimula a divisão do todo em fragmentos organizados, nos quais essa multiplicidade seja reduzida. A existência de infinitas possibilidades de atividades, ações, seleções e sentidos aumentaram ao longo do processo histórico e uma das funções dos sistemas é organizar parte dessa complexidade a partir de seleções de elementos que farão parte deste espaço interno organizado, o sistema.

A complexidade da sociedade estimula, portanto, a diferenciação entre sistema e ambiente e, consequientemente, a formação dos diversos sistemas. Esse processo é a delimitação de uma fronteira, uma diferenciação de uma parte do todo, e cria um espaço interno, dentro do qual é realizada uma operação de dotação de sentido a uma parcela daquela sociedade ampla.

Os sistemas limitam a um número reduzido o conjunto das inúmeras operações sociais com possibilidade de fazerem parte do rol de suas operações internas, que serão dotadas de sentido a partir da diferenciação entre a organização interna do sistema e o restante da sociedade.

Ao estabelecer a fronteira entre uma parcela e o resto da sociedade, o sistema passa a elaborar uma releitura das informações externas e a filtrar a influência de outros âmbitos naquela área restrita. Isso faz com que muitas variáveis deixem de ser levadas em consideração e, em um momento imediatamente posterior, muitas outras comecem a ser criadas, mas então já como variáveis internas e próprias do sistema.

A formação dos sistemas sociais é definida, dentro da teoria, pela operação básica por meio da qual a sociedade complexa é dividida em dois campos: um sistema e o seu ambiente, formado por tudo o que não está no interior do sistema.

Esta operação básica significa a constituição de uma fronteira, de uma linha que organiza o mundo em duas partes e, ao dividi-lo, identifica o que está dentro e o que está fora do sistema social constituído. Esta linha marca a diferença e encerra em si uma distinção entre os elementos que farão parte do sistema e todo o resto dos elementos presentes na sociedade, 
que passam a figurar como elementos externos e não pertencentes àquele domínio diferenciado .

Toda linha constitui uma fronteira e ao mesmo tempo uma forma, pois para distinguir o que está dentro e o que está fora do sistema é necessário estabelecer uma separação e uma identificação de quais características compõem os elementos que fazem parte do sistema.

Esses elementos tornam-se mais rigidamente conectados do que os elementos que permaneceram no ambiente. A conexão destes elementos obedece a padrões de funcionamento do próprio sistema, que agora organizam aquela parcela de elementos internalizada no sistema de maneira a torná-la reconhecível.

Essa identificação dos elementos internos é definida a partir da forma que organiza o espaço e compõe configurações mais estáveis dentro do sistema. A forma, como fronteira da diferenciação sistêmica, é definida a partir da instauração de um medium. Cada sistema, como veremos adiante, estabelece um medium específico para possibilitar as operações internas. São os meios de comunicação simbolicamente generalizados (symbolisch generalisierten Kommunikationsmedien). "Chamamos de 'simbolicamente generalizados' os media que utilizam generalizações para simbolizar a relação entre seleção e motivação, ou seja, representá-la como uma unidade. São importantes exemplos: verdade, amor, propriedade/dinheiro, poder/lei e também, em uma forma rudimentar, crença religiosa, arte e, hoje em dia, "valores básicos' padronizados". ${ }^{8}$

É por esse mecanismo, a organização da forma através de um medium, que os processos comunicativos internos se organizam. No funcionamento dos sistemas sociais, a forma organizada, os elementos internos, os processos de dotação de sentido são traçados a partir deste meio de comunicação simbolicamente generalizado, ou seja, uma estrutura exclusiva do sistema que aumenta a possibilidade de reconhecimento da forma assumida dentro do sistema, seja pelos outros elementos e processos comunicativos do sistema, seja por um observador externo.

Na relação entre ambiente e sistema, decorrente da separação inicial e da formação de uma fronteira entre o sistema constituído e o ambiente, ambas as partes se determinam, uma em diferenciação à outra: o que faz parte do sistema e o que não faz parte do sistema. Assim, sistema e ambiente podem ser compreendidos como dois campos complementares, no sentido

\footnotetext{
${ }^{8}$ Luhmann, N. Soziale Systeme. Grundri $\beta$ einer allgemeinen Theorie. Frankfurt a.M., Suhrkamp, 1991, p. 222.
} 
de comporem a sociedade complexa, apesar de não terem elementos em comum e estarem separados por uma fronteira que os diferencia. Dessa forma, tudo que ocorre na sociedade pertence a um sistema ou ao seu ambiente e, por conseqüência, toda transformação num sistema é a transformação no ambiente de outros sistemas. ${ }^{9}$

Sistema e ambiente não operam em conjunto ou influenciam as operações um do outro; no entanto, os sistemas não conseguiriam sobreviver de maneira autônoma e completamente diferenciada se fossem anacrônicos em relação ao ambiente, pois não conseguiriam estabelecer nenhuma forma de convivência adaptativa ou de utilização dos elementos de outros sistemas para possibilitar a operação de seus próprios elementos.

As operações de adaptação do sistema social ao ambiente - e conseqüentemente a outros sistemas sociais presentes no ambiente - e de co-evolução, sem a necessidade de determinações mútuas entre sistema social e ambiente e outros sistemas sociais, são possibilitadas por meio do mecanismo de acoplamento estrutural entre o sistema social constituído e elementos do ambiente, sejam eles outros sistemas sociais ou sistemas psíquicos (psychisches System).

$\mathrm{Na}$ sociedade há diversas distinções de sistema-ambiente simultâneas e há a possibilidade de uma determinada distinção ser criada a partir da diferenciação de seus elementos, para que possam gerar formas de observar outros sistemas e as respectivas distinções em relação aos ambientes existentes no espaço desorganizado.

A complexidade do ambiente é sempre maior do que a complexidade interna do sistema. Diminuir a complexidade do ambiente externo para que haja uma delimitação de sentidos e estruturas é uma das funções dos sistemas.

Os sistemas consolidados têm habilidade para estabelecer relações internas e diferenciar essas relações das relações com o ambiente. ${ }^{10}$ Esse é o princípio do fechamento operacional (operative Schließung) - característica básica da organização dos sistemas.

\footnotetext{
${ }^{9}$ Cf. Luhmann, Soziale Systeme, op. cit., p. 243.

${ }^{10}$ Cf. Luhmann, Soziale Systeme, op. cit., p. 31.
} 


\section{2 Sistema operacionalmente fechado (operativ geschlossenes System)}

A principal característica dos sistemas, sejam sociais ou psíquicos, que são os que nos interessam, na concepção luhmanniana, é o fechamento operacional por meio da autopoiése (Autopoiesis). Os sistemas sociais, mediante a autopoiése, geram e reproduzem internamente seus próprios elementos de funcionamento sem a interferência ou influência de elementos externos. Os sistemas sociais são, portanto, sistemas auto-referenciais, ou seja, todos os processos comunicativos internos dizem respeito a elementos internos e são definidos a partir de orientação interna.

Os sistemas sociais são sistemas autopoiéticos (autopoietische Systeme) e, dessa maneira, não podem ser determinados por meio de acontecimentos do ambiente. Todas as operações internas são constituídas de processos comunicativos próprios e exclusivos, que determinam a unidade e a identidade do sistema.

Todo novo elemento operativo do sistema é gerado a partir dos elementos anteriores e se torna, ao mesmo tempo, pressuposto para a elaboração dos elementos posteriores do sistema.

Dessa forma, por exemplo, dentro do sistema direito (Recht), os processos comunicativos válidos são determinados pela oposição lícito/ilícito e produzem elementos que vão operar a partir desses pressupostos. Dentro deste sistema, portanto, os elementos de funcionamento, como as leis, as sentenças, os pareceres etc. tratam desta oposição e fazem referência a elementos da mesma natureza e são pré-requisitos para a elaboração de novos elementos dentro do sistema.

A manutenção da capacidade dos sistemas de produzir seus elementos internos é a própria manutenção de sua sobrevivência, pois significa manter sua diferenciação em relação ao ambiente. Isso não significa, no entanto, que o sistema não reconheça a existência do ambiente, mas que opera a partir de construções próprias. "O fechamento operacional não pode significar jamais que um sistema autopoiético opere como se não houvesse nenhum ambiente."11

\footnotetext{
${ }^{11}$ Luhmann, N. Die Politik der Gesellschaft. Frankfurt a. M., Suhrkamp, 2002, p. 372.
} 
A propriedade do fechamento operacional garante ao sistema social a capacidade de produzir sentidos internamente e, desta forma, manter abertas as possibilidades de criação de novos elementos. Paradoxalmente, o fechamento abre caminho ao sistema para produzir sentido, a partir de informações presentes no ambiente, pois mantém o sistema em operação com elementos próprios, ao mesmo tempo em que leva em consideração ruídos externos para elaborar os processos comunicativos internos.

Essa capacidade de produzir sentido e abrir novas possibilidades dentro do sistema, a partir de informações externas, não contradiz o fechamento operacional, pois essas informações (Informationen) externas não se constituem em elementos operacionais do sistema, mas em irritação (Irritation), perturbação e ruído para o sistema. "Por fechamento operacional não se entende $\mathrm{o}$ isolamento termodinâmico, mas somente a autonomia operacional, isto é, que as operações próprias do sistema se tornem possíveis recursivamente por conta dos resultados das próprias operações do sistema."12

A irritações externas o sistema responde com elaborações próprias, com a utilização de elementos pré-existentes dentro do sistema, que não são conhecidos nem previstos por um observador no ambiente. Os sistemas sociais e os processos comunicativos internos estão acondicionados numa caixa-preta, opaca à observação externa.

Essa impossibilidade de previsão pelo ambiente externo das respostas do sistema social a irritações externas, para as quais há uma gama de possibilidades, gera o conceito de contingência, ou seja, não há como uma informação externa pré-determinar uma resposta interna do sistema - em verdade, nem mesmo as decisões internas podem ser pré-concebidas, visto que também internamente há contingências que possibilitam processos evolutivos do sistema. Assim, qualquer estímulo externo, como irritação ou ruído, que interesse ao sistema social operacionalmente fechado, é internalizado a partir de processos internos de dotação de sentido. O ruído externo é selecionado entre os estímulos externos e é transfigurado em informação para a utilização interna como parte do processo comunicativo. A elaboração do sentido desta informação, no entanto, é realizada internamente, tornando sem importância o sentido que aquele ruído tinha em seu contexto original

${ }^{12}$ Luhmann, N. \& De Georgi, L. Teoría de la sociedad. Guadalajara, Prensa de la Universidad de Guadalajara, 1993, p. 50. 
Os sistemas sociais são autopoiéticos porque seu elemento essencial, o processo comunicativo "pode ser produzido apenas no contexto recursivo com outros processos comunicativos, e apenas em uma rede, em cuja reprodução cada processo comunicativo singular colabora" ${ }^{, 13}$, isto é, ainda que haja a utilização de elementos externos para a elaboração de um processo comunicativo, esse elemento externo constitui uma irritação e não um elemento de interconexão interna.

Os processos comunicativos internos dos sistemas sociais constituem-se de três componentes e apenas um deles é informação, que pode provir do ambiente, sem que, no entanto, o processamento e as formas de organização e reação sejam provenientes do ambiente. Os outros componentes dos processos comunicativos são a participação (Mitteilung) e a compreensão (Verstehen).

Esse desenvolvimento interno é paradoxal: os sistemas podem reforçar sua diferenciação com o ambiente pela "abertura" do próprio sistema, a partir de perturbações que lhes causam os ruídos do ambiente. Destas perturbações, por meio de elaborações internas do sistema, originam-se elementos ordenadores internos que aumentam sua complexidade e, conseqüentemente, os elementos de distinção para com o ambiente, e assim sucessivamente. ${ }^{14}$ Esse processo contínuo de diferenciação, a partir da utilização de elementos do ambiente, mantém o sistema em funcionamento e assegura sua existência.

O termo "abertura" é utilizado aqui apenas para apresentar a idéia de que elementos externos são considerados, mas não são considerados "in natura". O sistema os observa, os percebe e, se preciso, os "traduz" a partir de seu próprio meio de comunicação simbolicamente generalizado, até mesmo para garantir sua autopoiése.

É por essa "abertura" que o sistema consegue realizar o mecanismo de acoplamento estrutural e, sem internalizar elementos estruturais do ambiente, gerar seus elementos internos. Os sistemas sociais mantém com os sistemas psíquicos, por exemplo, esse tipo de relação, pois os pensamentos, os sentimentos e as motivações de pessoas ${ }^{15}$ possibilitam ao sistema continuar funcionando e gerando seus elementos internos.

\footnotetext{
${ }^{13}$ Luhmann, N. Die Gesellschaft der Gesellschaft, Frankfurt a. M., Suhrkamp, 1998, p. 83.

${ }^{14}$ Cf. Luhmann, Soziale Systeme, op. cit., p. 250.

${ }^{15}$ Pessoa para o entendimento teórico sistêmico é a forma com que o ser humano, dotado de sua consciência e corpo, portanto um acoplamento estrutural entre o sistema psíquico e o sistema biológico, adquire sentido em uma observação de um sistema social. Assim, a forma pessoa só se coloca como uma forma quando adquire
} 
A pessoa constitui assim, para o sistema, parte do seu ambiente, pois o que gera sentido e faz o sistema operar são processos comunicativos e não processos mentais, como pensamentos, mas estes possibilitam aos processos comunicativos internos do sistema irritações, que podem ser apropriadas como informação para as seleções internas próprias do sistema em questão.

Como os elementos de cada um dos sistemas são diferentes - o dos sistemas psíquicos são pensamentos e o dos sistemas sociais são processos comunicativos - os elementos do sistema psíquico jamais poderão substituir elementos do sistema social no seu funcionamento interno e vice-versa.

sentido para um processo comunicativo de um sistema social ou de observação de um sistema social ou de outra pessoa, com a formação da dupla contingência. No caso em questão, as pessoas tomam parte em comunicações de sistemas sociais, possibilitando a auto-reprodução destes sistemas. Para mais detalhes: Luhmann, N. Complejidad y Modernidad. Madrid, Editorial Trotta, 1998, pp. 231 e seguintes. 


\section{3 Processos comunicativos (Kommunikationen - Kommunikationsprozesses)}

Os processos comunicativos, que são o elemento constituinte dos sistemas sociais, são mais do que mensagens ou informações. Eles constituem o modo como os sistemas sociais se organizam.

Os processos comunicativos são, para Luhmann, constituídos de três partes inseparáveis, mas diferentes. Essas partes são: informação, participação e compreensão. Esses três elementos do processo comunicativo são três operações distintas de seleção e em cada um deles uma escolha é realizada. Há, então, uma escolha da mensagem - que representa uma distinção entre elementos válidos e não-válidos como elementos de comunicação -, uma escolha da forma da participação - por exemplo, a seleção das palavras que serão utilizadas para expressar a mensagem selecionada - e da estrutura de compreensão - o conjunto de processos comunicativos anteriores com os quais a nova informação será combinada e o conjunto de processo comunicativos posteriores para os quais a nova informação será utilizada como premissa. ${ }^{16}$ Essas escolhas são realizadas de acordo com o repertório à disposição e, por isso, quanto mais o sistema é consolidado e desenvolvido, mais conhecido e generalizado é o repertório e mais provável que o processo comunicativo se complete.

Nesses sistemas complexos e consolidados, esse processo comunicativo tem mais chances de transmitir mensagens de modo mais eficaz, porque já há um histórico de processos completados e algumas expectativas de funcionamento destes processos.

A abordagem do processo comunicativo na teoria dos sistemas sociais abandona a metáfora da transferência onde, grosso modo, o emissor entrega alguma coisa que é recebida pelo receptor ${ }^{17}$. O fundamental deste conceito, na concepção luhmanniana, é a existência das três partes constitutivas. Para Luhmann, qualquer uma das três partes isoladas torna-se apenas uma proposta de seleção, um estímulo. O processo comunicativo necessita dos três elementos básicos para se completar. Para cada uma das seleções propostas é necessário que o estímulo seja recolhido e processado.

O primeiro dos três elementos, a informação, já constitui a primeira seleção a partir de um repertório, conhecido ou desconhecido, de possibilidades. É esse elemento que pode ter sua origem em qualquer local do sistema ou mesmo do ambiente. Como informação, o

${ }^{16}$ Cf. Luhmann, Soziale Systeme, op. cit., p. 196. 
sistema pode utilizar qualquer estímulo que exista e que lhe seja possível observar, selecionar dentre os diversos estímulos existentes, apropriar-se e dotar de sentido, a partir dos elementos internos de organização do sistema.

O segundo elemento do processo comunicativo, a participação, representa um comportamento que notifica o sistema e os elementos internos que uma informação foi selecionada anteriormente. Esta notificação pode ocorrer intencionalmente ou não.

O terceiro elemento, a compreensão, ocorre quando é observada a diferença entre informação e enunciação; então, é atribuído um sentido a esta diferença a partir do repertório disponível no sistema. Com a compreensão, todo o processo se completa e há a geração de mais um elemento que será incorporado ao repertório interno do sistema. Esse novo elemento torna-se pressuposto para a formação de novos elementos.

O processo comunicativo é a síntese de informação, participação e compreensão, que não podem existir separadamente, assim como não se relacionam de forma hierárquica ou com qualquer afirmação de causalidade necessária entre uma e outra. Além disso, estes elementos, entendidos como processos seletivos, apenas se apresentam no interior do processo comunicativo, nunca isoladamente. Informação, participação e compreensão apenas integram o processo comunicativo quando são resultados de seleções realizadas dentro do sistema social.

A construção do sentido pelo sistema, como uma das partes do processo comunicativo, é fruto de uma seleção de cognição, ou seja, seleção de elementos internos para a compreensão da mensagem e para a produção de um novo elemento constituinte daquele sistema. Neste momento, a operação fundamental é a seleção de quais elementos poderão ser utilizados para esse processo de apropriação da informação; a seleção interna é, portanto, de extrema importância para o desenvolvimento dos sistemas, porque é essa seleção que possibilita ao sistema ampliar seu repertório de elementos e completar o processo comunicativo e o desenvolvimento cognitivo, ao mesmo tempo em que mantém sua autopoiése e seu fechamento operacional.

Os elementos do processo comunicativo - informação, participação e compreensão, são subsequientes e complementares, mas sua presença não garante nenhum tipo de resultado prático definido. Isso quer dizer que a presença das três partes constitutivas da comunicação

\footnotetext{
${ }^{17}$ Cf. Luhmann, Soziale Systeme, op. cit., p. 193.
} 
não garante que uma mensagem seja entendida de uma maneira pré-definida ou que exista um modo eficaz de transmitir informações com resultados previamente conhecidos. O histórico dos processos comunicativos já realizados e o repertório do sistema aumentam a chance de novos processos comunicativos serem realizados, mas não garante sob quais formas ocorrerão exatamente e muito menos qual será o resultado final das seleções do processo comunicativo.

Não é, pois, um resultado final específico pré-determinado que garante a existência do processo comunicativo, mas a presença efetiva de suas três partes constitutivas. Pode ocorrer de não haver um planejamento prévio, apenas expectativas (Erwartungen), mas a comunicação consegue realizar-se porque alguma seleção ensejou a compreensão, por parte de Alter, de algum elemento externo, ruído, irritação, que foi dotado de sentido dentro do sistema.

Um movimento de braço de uma pessoa pode significar muitas coisas, e em determinados contextos pode significar nada. Por exemplo, em uma sala de aula, quando um aluno levanta uma das mãos para, com a outra, coçar o antebraço, o professor pode interpretar aquele movimento como um pedido de palavra. Isso pode ser o código daquela aula - que pode ser compreendida como um sistema em operação, mais especificamente, como um sistema de interação. $\mathrm{O}$ aluno, constrangido pela situação, pode tomar a palavra e realizar uma intervenção. Nesse caso, o processo se completa sem necessidade de um planejamento prévio, mas as seleções presentes no processo comunicativo foram realizadas: o aluno poderia coçar o antebraço sem levantar a mão, o professor poderia não atender ao pedido e, por fim, o aluno poderia desfazer o mal-entendido.

Um conteúdo informativo em um processo de comunicação pode, então, exercer apenas um papel de deflagrador do processo; a partir daí outras seleções são realizadas pelo sistema para levar adiante aquele processo, ou abortá-lo. Neste sentido, as informações são, a princípio, apenas irritação e perturbação para o sistema, antes de se completar o processo comunicativo.

Para esse processo comunicativo se concretizar, a enunciação daquela informação precisa ser completada, o sistema precisa selecionar aquela enunciação e validá-la pelo reconhecimento de sua forma e, finalmente, há a necessidade de uma compreensão pelo sistema daquela informação como uma mensagem válida. 
Apenas o funcionamento de um dos elementos do processo não garante seu pleno funcionamento. Assim, a simples percepção dos sinais e informações existentes não se completa como processo comunicativo se estes sinais percebidos não são convertidos em enunciações e compreensões selecionadas pelo sistema como válidos.

O processo comunicativo não é, também, apenas uma linguagem, entendida aqui como um conjunto de regras de combinações de sinais, sons e imagens. Estas combinações, que podem ser, por exemplo, uma língua, são apenas o medium, o excipiente pelo qual a mensagem e o processo comunicativo são organizados. Todo o processo comunicativo está inscrito no campo da semântica (Semantik), ou seja, não na forma da linguagem, mas na do sentido que é dado às seleções de informação, participação e compreensão.

Imaginemos, por exemplo, que um agente econômico teve uma idéia para aumentar o rendimento de determinada aplicação financeira. Para realizar aquela idéia ele precisa contatar outro agente e explicar esta idéia a fim de colocá-la em prática. Ele pode escolher ligar, escrever um bilhete, mandar um sinal luminoso na tela do computador ou encontrar o outro agente e fazer sinais para que este o compreenda. Qualquer uma dessa formas de se comunicar não está relacionada diretamente com o mundo das aplicações financeiras ou com a forma mais eficaz de atingir o objetivo a que se propôs o agente, mas se constituem apenas em condutor de uma comunicação daquele sistema operacionalmente fechado, nesse caso o sistema econômico. Sendo realizadas as operações financeiras, que é o processo comunicativo válido no sistema, a linguagem utilizada para a construção do sentido neste âmbito pode ser variada.

Uma importante consideração a ser feita em relação aos processos comunicativos é a de que a percepção pelas consciências (sistemas psíquicos), por exemplo, não é comunicável, porque apenas os processos comunicativos são comunicáveis. Ao ter condições de se referir a qualquer coisa e utilizar qualquer substrato como informação selecionada para se completar, o processo comunicativo pode, inclusive, referir-se às percepções, mas isto acontece unicamente porque esta possibilidade já foi desenvolvida por um processo comunicativo prévio e as percepções não constituem elemento de operação daquele processo comunicativo, mas informação selecionada para dar início ao processo comunicativo que tratará daquele aspecto. O processo comunicativo só é possível na rede recursiva de outros processos comunicativos, sendo a percepção apenas uma parte, uma informação selecionada, do 
processo inteiro. Para diferenciar claramente os processos comunicativos, operações dos sistemas sociais, dos pensamentos, operações dos sistemas psíquicos, basta a compreensão de que não é possível a comunicação de pensamentos e de que os pensamentos continuam a operar mesmo quando não há processos comunicativos ocorrendo.

Por último devemos destacar que os processos comunicativos não são ações ou uma sucessão de ações ${ }^{18}$ - ponto onde podemos notar a diferença de Luhmann em relação a Parsons e a outros teóricos funcionalistas tradicionais. O processo comunicativo encerra mais do que simplesmente a finalização de uma atividade, ele pressupõe uma seletividade em todas as suas etapas e a diferenciação de todas elas, assim como a abertura para outros processos que não foram concretizados. O processo comunicativo, mais do que definir um ato, pressupõe alternativas, define seleções, gera formação de novos elementos constitutivos do sistema e cria subsídios para que outras seleções e outros processos comunicativos possam ser iniciados e completados.

\footnotetext{
${ }^{18}$ Cf. Luhmann, Soziale Systeme, op. cit., p. 225.
} 


\section{4 Meios de Comunicação Simbolicamente Generalizados (symbolisch generalisierte Kommunikationsmedien)}

Como vimos, o processo comunicativo é o elemento de operação dos sistemas sociais. É mediante o processo comunicativo que os sistemas sociais comunicam suas diferenciações e seleções e produzem novos processos comunicativos. Para atingirem sua autopoiése e completarem seu fechamento operacional, os sistemas elaboram uma diferença fundamental em relação ao ambiente, uma fronteira, que define o que faz parte do sistema e o que está no ambiente. Essa fronteira é definida a partir de uma marca, uma linha. Isso é a própria geração de uma forma, pois toda marca produz automaticamente uma forma.

Os sistemas sociais desenvolvem os seus processos comunicativos levando em consideração seu fechamento operacional e sua autopoiése e têm que observar aquela forma definida por ele mesmo. Para dar eficácia à forma estabelecida e à diferenciação sistemaambiente, o sistema estabelece um medium, uma estrutura de comunicação que realize as operações internas ao mesmo tempo em que seja capaz de garantir que essa realização observe a diferenciação da forma.

O processo comunicativo tem que ser conduzido respeitando a estrutura do medium estabelecido, a fim de que seja preservada a forma e, portanto, a diferenciação do sistema em relação ao ambiente. Tanto o medium quanto a forma têm de garantir essa diferenciação entre sistema e ambiente, mas em um caso, na forma, os elementos estão conectados estritamente, ou seja, compõem uma estrutura definida e observável, os sistemas sociais e sua fronteira. Já no caso do medium, os elementos se conectam sob determinada estrutura, mas a conexão se desfaz no momento seguinte, já que o medium funciona como um excipiente de sentidos, de processos comunicativos e da forma. ${ }^{19}$

Podemos facilmente entender esta conceituação quando tomamos a língua como a forma e a utilização dessa língua nas diversas formas de expressão como o medium. Assim, a estrutura que sustenta as regras gramaticais da língua e o léxico que forma seu repertório delimitam o que faz parte daquela língua e o que não faz parte. Já as várias expressões da língua, a linguagem, os discursos e as sentenças conectam as palavras de maneira fugaz. Um discurso é uma expressão da língua, mas a cada discurso as palavras serão organizadas de

\footnotetext{
${ }^{19}$ Cf. Luhmann \& De Georgi, Teoría de la sociedad, op. cit., p. 86.
} 
forma diferente, muitas vezes com sentidos diferentes. Assim, mesmo que consideremos um discurso apenas uma parte da língua, ele se basta para dar a conhecer qual língua está sendo utilizada, quais regras são válidas (pelo próprio reconhecimento da língua), ao mesmo tempo em que pode no momento seguinte desaparecer, ou então organizar os elementos, neste caso as palavras, em um novo ordenamento e, assim, dar outro sentido ao discurso.

Determinados media são utilizados de maneira indiscriminada pelos diversos sistemas sociais, por exemplo, a própria linguagem, isto é, alguns media não constituem em si um elemento de diferenciação do sistema social (apesar de poder constituir um elemento de diferenciação de outros tipos de sistemas), mas servem de meio para que a forma seja apresentada, auxiliando a dotação de sentido ao processo comunicativo pelo sistema e assim promovendo a diferenciação do sistema, o fechamento operacional e a evolução dos sistemas.

Em outros casos, os media são em si estruturas que diferenciam o sistema do ambiente e geram alguns sentidos amplamente escorados em pressupostos anteriores. São os chamados meios de comunicação simbolicamente generalizados. Eles têm a função de aumentar a probabilidade de as outras funções do processo comunicativo serem concluídas; isto não significa, no entanto, que o medium possa ser titular de decisões, sentido e racionalidade. Ele continua sendo meio para as decisões do sistema, como a linguagem.

Mesmo os meios de comunicação simbolicamente generalizados são estruturas de conexão efêmera - acoplamentos frouxos - e constituem o excipiente dos sentidos e processos comunicativos do sistema. O medium não comunica por si mesmo. A diferença dos meios de comunicação simbolicamente generalizados, neste caso, é a de que estes pressupõem um histórico mais longo de premissas diferenciadas em relação ao ambiente, que condensam mais fortemente os sentidos de seus elementos, gerando uma codificação binária da linguagem: sim e não como resposta à apropriação do processo comunicativo como premissa para processos comunicativos posteriores. $^{20}$

Como exemplos de meios de comunicação simbolicamente generalizados podemos indicar a propriedade e o dinheiro, que codificam a oposição binária ter/não ter no sistema economia, o poder, que codifica a oposição governo/oposição no sistema política, e a teoria e o método, que codificam a oposição válido/não válido, no sistema ciência.

\footnotetext{
${ }^{20}$ Cf. Luhmann \& De Georgi, Teoría de la sociedad, op. cit., p. 126.
} 
Essa codificação possibilita uma generalização da utilização desses media e estrutura as relações e os processos comunicativos. Esta estruturação, no entanto, não pressupõe o direcionamento do processo comunicativo nem garante a continuidade da operação sistêmica ou mesmo a aceitação do processo comunicativo como pressuposto de um novo processo comunicativo. Apenas aumenta as possibilidades de isto ocorrer, auxiliando o processo autopoiético e a evolução do sistema, ao mesmo tempo em que reforça os referenciais e as premissas sobre as quais o processo comunicativo se completou.

Assim, o meio de comunicação simbolicamente generalizado promove uma certa estabilidade do sistema, à medida que condensa sentidos e estabelece a ligação entre as premissas de decisões e processos comunicativos posteriores. Esses media estruturam, portanto, a improbabilidade de o processo comunicativo ser aceito em formas que podem ser invocadas para possibilitar essa aceitação.

É importante notar que apenas sistemas que desenvolvem uma alta complexidade de seus elementos e uma alta complexidade na utilização da linguagem conseguem desenvolver um meio de comunicação simbolicamente generalizado. Apenas depois de gerar um grande número de possibilidades de produção de sentido e processos comunicativos internos o sistema pode condensar em um código binário os sentidos sistêmicos. Os meios de comunicação simbolicamente generalizados estão, portanto, ligados à evolução dos sistemas sociais.

Poder-se-ia objetar que sociedades segmentares ${ }^{21}$ não atingiram tal complexidade e, ainda assim, apresentam seu meio de comunicação simbolicamente generalizado - a saber o código de valores tradicionais que organiza suas bases. Ocorre que essas sociedades, apesar de indiferenciadas funcionalmente, isto é, de não apresentarem a complexidade interna da sociedade contemporânea, funcionam elas mesmas como sistemas complexos. Sem diferenciação interna, todos os processos comunicativos são reproduções de um único código abrangente, porém complexo, como podemos verificar por meio dos trabalhos de estudos de

\footnotetext{
${ }^{21}$ Para Luhmann, a diferenciação da sociedade evoluiu da divisão segmentar para a estratificada, até chegar à diferenciação funcional contemporânea. Na primeira, os sistemas parciais eram famílias e clãs, não havia mediação na comunicação, que se dava inteiramente via interações. Além disso, a diferenciação segmentar se repetia em todas as esferas da vida social. $\mathrm{Na}$ estratificada, foi introduzida a diferenciação hierárquica, que dividida a sociedade em nobres e povo, diferenciações dentro das quais se desenvolvem diferenciações posteriores. Nessa sociedade, há a possibilidade de aumento de complexidade, sobretudo nos estratos superiores. Cf. Baraldi, C., Corsi, G. \& Esposito, E. Glossar zu Niklas Luhmanns Theorie sozialer Systeme. Frankfurt a.M., Suhrkamp, 1999, pp. 65-67.
} 
parentesco nas sociedades tribais ${ }^{22}$. Assim, é inegável que elas dispõem de uma complexidade considerável capaz de gerar um meio de comunicação simbolicamente generalizado, ainda que seja este o único meio disponível naquela sociedade, tomada então como um sistema social coeso, mas complexo.

Apesar de o meio de comunicação simbolicamente generalizado constituir um modelo e uma forma estruturada, as possibilidades de evolução são mantidas, já que a contingência das respostas permanece existindo - pela possibilidade de novas dotações de sentidos aos mesmos termos do processo comunicativo, devido à alta complexidade no uso da linguagem. O meio de comunicação simbolicamente generalizado não estabelece uma relação teleológica com os elementos do processo comunicativo, mas, a partir do aumento da complexidade interna, passa a estruturá-los.

Esses media aumentam a estabilidade do sistema e condensam sentidos do sistema ao mesmo tempo em que possibilitam a evolução do próprio medium e do sistema e também a diferenciação com o ambiente. Podemos entender essa dupla caracterização observando que mesmo com a evolução das relações econômicas e o aparecimento de novas expressões do medium propriedade - primeiramente meios de troca, posteriormente ouro, dinheiro, papelmoeda, a seguir capital volátil, fundos de investimento virtuais, títulos digitalizados. Em todos esses casos, o medium evolui, mas a oposição básica ter/não ter é mantida, assim como é mantida a diferenciação do sistema econômico com o ambiente.

Essa evolução dos meios de comunicação simbolicamente generalizados constitui a formação de um código secundário ${ }^{23}$. Trata-se de um avanço técnico nas operações do código e os exemplos mais importantes são o acima citado - no qual o código do sistema economia a propriedade - se transfigura em outros meios, que oferecem outras possibilidades de redução da complexidade, ao mesmo tempo em que possibilitam o aumento do número de operações válidas e o conseqüente aumento dessa mesma complexidade -, o aparecimento do direito como código secundário do poder, no qual as operações de governo/oposição assumiram

\footnotetext{
${ }^{22}$ Para mais ver: Laraia, R. (org.) Organização Social. Rio de Janeiro, Zahar, 1969; Radcliff-Brown, A. R. Introdução a sistemas africanos de parentesco e casamento. Lisboa, Gulbenkian, 1974; Evans-Pritchard, E Os Nuer. São Paulo, Perspectiva, 1978 e Viveiros de Castro, E. (org.) Antropologia do parentesco. Estudos ameríndios. Rio de Janeiro, UFRJ, 1995, nos quais são apresentadas a complexidade e o funcionamento dos códigos sob os quais se desenvolvem as relações sociais em algumas sociedades segmentares, e Geertz, C. A Interpretação das Culturas. Rio de Janeiro, Zahar, 1978, onde o autor expõe um conceito de cultura, segundo o qual os homens constroem representações cognitivas, mapas mentais que orientam suas ações, teias de significados, mesmo em sociedades tomadas como tradicionais.
} 
outras formas de operacionalização, gerando um sistema autônomo ${ }^{24}$, e o desenvolvimento do método como expressão secundária da ciência - a partir das exigências internas de fundamentação científica das próprias teorias científicas.

Além de aumentarem a probabilidade de comunicação nos sistemas sociais, os meios de comunicação simbolicamente generalizados auxiliam a realização dos programas de certos sistemas sociais.

${ }^{23}$ Cf. Luhmann \& De Georgi, Teoría de la sociedad, op. cit. p. 165 e seguintes.

${ }^{24} \mathrm{O}$ sistema primordial que utiliza o poder como meio de comunicação simbolicamente generalizado é o sistema política, sendo o direito uma expressão secundária. A evolução interna da expressão secundária, no entanto, acabou por gerar um sistema autopoiético independente. A relação de ambos os sistema com o código poder é objeto de análise de alguns trabalhos em andamento no campo da análise sistêmica. 


\section{5 Programas (Programme)}

Os programas constituem as formas de controle interno das operações dos sistemas sociais. Através dos programas, os sistemas podem realizar a verificação do direcionamento dessas operações, já que estas evoluem e ocorrem de maneira indeterminada e contingente. Por meio dos programas, os sistemas estabelecem as condições sob as quais determinados processos comunicativos podem ocorrer ou os processos comunicativos que devem suceder a ocorrência de determinadas operações internas.

Os programas, ao contrário dos códigos binários e dos meios de comunicação simbolicamente generalizados, são flexíveis ${ }^{25}$ e dependem do direcionamento que o sistema social assume ao longo do seu processo de evolução. A programação dos sistemas sociais, no entanto, está sempre referenciada em seus próprios códigos internos, ainda que essa programação possa levar em consideração condições do ambiente para ordenar a sucessão de operações internas.

Um dos principais aspectos da programação são os critérios estabelecidos para a seleção dos processos comunicativos que deverão ser selecionados como requisitos. Esses critérios são, ao mesmo tempo, definidores das operações que serão aceitas pelo sistema social como válidos, como também definiram muitos aspectos da evolução do sistema a partir de sua assunção para a regulação das operações de tal sistema. Essa definição é importante para o sistema porque, apenas a partir do código binário, ele não é capaz de selecionar quais serão os processos comunicativos que serão realizados com o código, que serve apenas para operacionalizar e não para verificar os requisitos de validade. A programação é, assim, complementar ao código binário na evolução do sistema. ${ }^{26}$

As expectativas de operações de Alter e Ego são bastante delineáveis no âmbito dos programas. Além disso, as expectativas podem ser conectadas em uma cadeia de operações que dependem entre si, tanto na dimensão da ocorrência propriamente dita, quanto na ordem e na determinação temporal dos diversos processos comunicativos. Dessa forma, os programas servem para diminuir sensivelmente a contingência dos processos comunicativos do sistema no qual opera o programa. Isso não significa que a contingência foi eliminada, nem que os

\footnotetext{
${ }^{25}$ Cf. Luhmann, Die Gesellschaft der Gesellschaft, op. cit., 1998, p. 771.

${ }^{26}$ Cf. Luhmann, N. Die Wissenschaft der Gesellschaft. Frankfurt a. M., Suhrkamp, 1992, p. 401
} 
resultados dos processos sobrecomunicativos possam ser previstos, mas apenas que objetivos prévios ou requisitos mínimos foram definidos.

Os programas mais comumente encontrados nos sistemas sociais são os finalísticos (Zweckprogramme) e os condicionais (Konditionalprogramme).

Os programas finalísticos coordenam as operações do sistema para determinados resultados elaborados internamente, que constituem o alvo da programação. Assim, o programa estabelece quais seleções devem ser consideradas válidas para atingir determinados fins e coordena a participação das pessoas nos diversos processos comunicativos.

O resultado positivo, que gera lucro, de determinada empresa é um programa do tipo finalístico exemplar. A partir desse objetivo, são montadas estratégias e planos de operação que coordenam todos, ou quase todos, os processos comunicativos dentro da organização. A partir dos programas, são inseridos, inclusive, critérios de seleção estranhos ao sistema. ${ }^{27}$

Já os programas do tipo condicional determinam situações e requisitos nos quais certos processos comunicativos deverão ser realizados. Essa determinação fornece a Alter e Ego os critérios sob os quais deve ser organizada a conduta dentro do sistema social no qual se desenvolve tal programa. A operação é avaliada, neste caso, a partir da observação do respeito ou obediência aos preceitos de tal programa.

Esses programas são responsáveis pelas interdições, pelos rituais, pelos costumes, em sistemas arcaicos ou no sistema religião, por exemplo, mas também pelo rol de procedimentos expressos pelos diversos códigos de processo, por exemplo, no sistema direito organizado de maneira moderna.

Os programas são responsáveis também pela transposição e utilização de processos comunicativos de outros sistemas para o âmbito interno do sistema em que opera a programação, a fim de aproveitar as condições exteriores para a consecução dos objetivos propostos pelo programa. ${ }^{28}$ Este desenvolvimento do funcionamento do programa será melhor analisado no capítulo IV, à luz do conceito de processo sobrecomunicativo, proposto neste trabalho.

${ }^{27}$ Cf. Baraldi, Corsi \& Esposito. Glossar, op cit., p.140.
${ }^{28}$ Cf. Baraldi, Corsi \& Esposito. Glossar, op cit., p.195. 


\section{6 Contingência (Kontingenz)}

A seleção dos caminhos e a formação dos elementos dos sistemas sociais, ou seja de seus processos comunicativos, são contingentes. Os sistemas sociais não são teleológicos e o direcionamento do desenvolvimento dos processos comunicativos internos não pode ser definido a priori. Para Luhmann, não há condições de existência ou operações previamente dadas nos sistemas sociais. A cada momento, o que era certo pode ser mudado e tomar outro rumo. Isso se aplica tanto às definições dos sistemas em relação ao ambiente, como do ambiente em relação ao sistemas, assim como às operações intra-sistêmicas.

A contingência dos processos comunicativos do espaço desorganizado é exatamente o estímulo para a formação dos sistemas, pois quanto mais um sistema se fecha e evolui, mais ele pode organizar, direcionar e limitar as possibilidades de caminhos de seu próprio funcionamento, em um processo de diminuição, dentro do sistema, da extrema contingência e complexidade do mundo desorganizado. Os sistemas sociais aparecem no processo histórico como a ordenação de uma determinada parcela do todo social, que começa a funcionar de maneira mais autônoma e previsível dentro de limites e fronteiras definidas pelo próprio sistema em suas operações iniciais e subseqüentes.

A contingência do mundo, porém, já é esperada pelos sistemas, que criam, então, seus mecanismos de seleção de operações, que passam a fazer parte do repertório do sistema. Essa seleção implica tentar se proteger da improbabilidade da comunicação, isto é, das dificuldades de os processos comunicativos se estabelecerem sem a estruturação de um sistema social, ou seja, no espaço desorganizado. Essa improbabilidade é diminuída pelo histórico dos repertórios de operações intra-sistêmicas e pela conexão das operações anteriores com as atuais, como pressupostos.

Essa conexão com operações intra-sistêmicas pré-existentes pode significar reiterações da mesma mensagem, repetições e decodificações prontas, que facilitam a seleção das operações posteriores. Esses mecanismos ajudam a superar aquela improbabilidade da comunicação e é esse mesmo o processo da formação do sistema, pois cada um desses processos comunicativos que se efetivam aparecem para o sistema como premissa de seleções posteriores e, conseqüentemente, do desenvolvimento do sistema. 
A contingência dos processos comunicativos, que é reduzida pelo desenvolvimento do repertório do sistema, com o desenvolvimento de um meio de comunicação simbolicamente generalizado, é potencializada, por sua vez, pela formação de expectativa de um elemento do sistema em relação ao outro, ou de Ego em relação a Alter, ambos operando em um mesmo sistema social.

Ainda que os sistemas limitem a gama de possibilidades de processos comunicativos intra-sistêmicos, as operações continuam contingentes e as expectativas continuam existindo em relação à aceitação de Alter e suas formas posteriores de operação, assim como em relação às construções auto-determinadas do próprio sistema. Tanto uma pessoa quanto outra nutre expectativas em relação ao comportamento do outro. Alter e Ego produzem expectativas um em relação ao modo de agir do outro reciprocamente. Isso pode ocorrer na própria formação de um sistema de dois elementos participantes que se inicie exatamente com tal processo comunicativo, uma interação, por exemplo. Trata-se da dupla contingência (doppelte Kontigenz). Na dupla contingência, Alter e Ego se relacionam e criam, ambos, expectativas em relação à operação do outro e à resposta futura do outro em relação à sua própria operação.

Estas expectativas são criadas também em relação ao desenvolvimento futuro do ambiente e da construção autopoiética do próprio sistema.

A dupla contingência também pode ser entendida, inicialmente, a partir das relações interativas, que são as relações em que as pessoas se relacionam dentro, e pelas regras, dos sistemas sociais. Uma pessoa espera que outra se comporte e se comunique de certas maneiras e se comporta e se comunica em relação a essa expectativa. Enquanto isso, o outro cria suas próprias expectativas que vão nortear, por sua vez, as suas próprias atitudes.

Tanto um (Ego) como outro (Alter) também têm expectativas sobre o modo como suas atitudes serão entendidas pelo interlocutor e isso também será base de tomada de decisão e de seleções posteriores tanto de um quanto de outro.

A relação que se forma pode ser entendida, neste sentido, como uma relação que necessariamente tem que levar em consideração o aspecto da negociação, porque assim como a tomada de decisão de um leva em consideração a tomada de decisão do outro, ela pode tentar condicionar a outra decisão a partir de sua própria. ${ }^{29}$ Esta situação, onde a decisão de

\footnotetext{
${ }^{29}$ Cf. Luhmann, Soziale Systeme, op. cit., p.166.
} 
um depende da decisão do outro, pode ser desfeita assim que um dos elementos desconsiderar a expectativa do outro; essa, entretanto, é uma situação propícia para a criação de um sistema social. Esse momento pode ser compreendido, se um sistema advir daí, como o ponto zero (Nullpunkt) deste sistema social consolidado, que pode evoluir ao longo do tempo.

Se os elementos continuarem a relação, é criado, como em todos os sistemas sociais, um repertório de decisões que restringem as próximas decisões e assim por diante, ainda que durante muito tempo, seja bastante grande a instabilidade e o risco de a relação ser desfeita. Esta instabilidade, no entanto, não é diferente da instabilidade que todos os sistemas sociais enfrentam.

A relação de dupla contingência não ocorre apenas no âmbito das relações entre sistemas sociais. Elas ocorrem também nas relações entre sistemas sociais e sistemas psíquicos, que englobam as interpenetrações (Interpenetrationen) entre estes sistemas - e entre sistemas psíquicos - as interações (Interaktionen). Podemos perceber, então, que Luhmann retira das categorias de sujeito e indivíduo a primazia no direcionamento das relações sociais e as coloca como um dentre vários fatores de perturbação e geração de informações para os sistemas sociais. Já não são os indivíduos que agem ou aguardam ações, mas sistemas que têm expectativas a respeito dos processos comunicativos de outro sistema.

Os sistemas não têm a expectativa de que suas operações sejam adotadas igualmente por outro sistema e sabem que o mesmo ocorre com a expectativa do outro sistema. As referências do sistema são voltadas para si, já que não podem prever ou definir a operação dos outros sistemas. Forma-se, nessa relação, uma equação com muitas variáveis que têm de ser levadas em conta pelos sistemas, como a expectativa de Alter sobre as operações de Ego e as expectativas de Ego em relação às operações de Alter.

Ego, então, tenta se antecipar à operação de Alter, gerando significado interno dentro do sistema e informação para fora: "Se Ego experimenta Alter como Alter e opera nesse contexto experimental, toda determinação que Ego dá para sua operação se refere a si mesmo. [...] A operação não compreende a si mesmo apenas como portadora de intenção, mas também (e em geral principalmente) como uma ação 'para você', 'contra você', 'frente a você', como uma ação significada para uma percepção, ou como um registro de sua própria intenção, que não quer ser compreendido como intenção de registro.”30

\footnotetext{
${ }^{30}$ Luhmann, Soziale Systeme, op. cit., p. 182.
} 
As expectativas e as operações são geradas pela observação mútua dos sistemas e muitas vezes essas expectativas são conflituosas e contraditórias. É nesse contexto que as relações de interação, interpenetração e acoplamento estrutural podem ocorrer. A observação e a relação entre os sistemas não pressupõem necessariamente, no entanto, nenhuma cooperação, coordenação ou simbiose. 


\section{7 Observação, auto-observação e observação de segunda ordem (Beobachtung, Selbstbeobachtung, Beobachtung zweiter Ordnung)}

A descrição das operações de um sistema só é possível a partir da observação (Beobachtung) de seu funcionamento. Essa observação ocorre, portanto, em um nível diferente do nível das operações do sistema propriamente ditas. Para uma descrição dos processos comunicativos é necessário um posicionamento externo, ou, pelo menos, desnivelado temporal ou estruturalmente, no caso das auto-observações.

Todo observador, por sua vez, constitui-se em um sistema autopoiético que produz seus sentidos internamente. Isso equivale a dizer que as descrições de um determinado sistema variam conforme o sistema que o observa e o descreve conforme o código válido dentro do sistema observador. Assim, é possível, ou melhor, provável, que a observação e a descrição de um sistema pelo outro produza um resultado diferente do obtido pelo processo de auto-observação. O sistema que observa e descreve não o realiza, e nem poderia, a partir de do repertório do sistema que é descrito.

Para produzir a auto-referência, no entanto, o sistema se auto-observa, mas não se descreve para outro sistema. Essa auto-observação tem a ver mais com o desenvolvimento de suas estruturas do que com uma descrição, é a expressão da racionalidade do sistema.

A auto-referência pressupõe uma auto-observação para a capacitação à diferenciação de seus próprios elementos dos elementos do ambiente. A auto-referência ocorre quando a própria operação de observação está incluída no panorama observado pelo sistema. Esta autoobservação, por sua vez, estimula uma observação do ambiente - para a operação de diferenciação -, que aparece ao sistema, senão como um todo desorganizado, pelo menos como uma série de pequenos compartimentos sem unidade. A resposta do sistema a esta realidade é a auto-organização: o fechamento operacional.

Isso não significa que o sistema se isola hermeticamente, apenas que precisa diferenciar suas operações internas das operações do mundo desorganizado, do ambiente, para estabelecer uma fronteira. Ao mesmo tempo em que esta fronteira é constituída com o auxílio da observação do ambiente, esta observação se torna pressuposto da manutenção da fronteira constituída. A observação do ambiente é, portanto, pressuposto para o mecanismo do fechamento operacional e para que, por sua vez, as operações próprias do sistema se tornem 
possíveis pelos resultados de outras operações do mesmo sistema. A observação do ambiente e a auto-observação ao mesmo tempo possibilitam e são possibilitadas pelo fechamento operacional dos sistemas. Temos que considerar que se pode comunicar dentro do sistema a respeito de seu ambiente, mas nunca com o ambiente.

Os sistemas, na constituição de seus elementos e de suas operações, fazem referência ao ambiente e a si mesmos; e, para tornar isto possível, os sistemas precisam elaborar e utilizar uma auto-descrição e uma descrição do ambiente. Além disso, têm que manter a capacidade de reconhecer e colocar em prática aquela diferença inicial entre ambiente e sistema que o originou. Aparentemente tautológica, esta diferenciação é necessária para que o sistema consiga gerar processos comunicativos a partir de elementos do ambiente que são internalizados no sistema social como informações, a partir do processo de observação.

Para que o sistema social seja capaz de selecionar irritações externas e reconhecê-las como informação, é necessário que ele consiga reconhecer a diferença entre o elemento externo e o elemento interno produzido a partir daquele elemento externo - com dotação de sentido a partir de um repertório de premissas próprias e com a diferenciação entre a autodescrição e a descrição do ambiente -, para evitar que elementos externos sejam utilizados dentro do sistema com seu sentido original. Caso contrário, a fronteira entre sistema e ambiente desaparece.

As referências internas, decorrentes de auto-observação, podem ser de três tipos: a auto-referência basal, na qual o que se diferencia e se auto-refere é um elemento do sistema; a reflexividade, ou auto-referência processual, na qual um elemento de um processo refere-se ao processo do qual faz parte, diferenciando estados anteriores e atuais, portanto levando em consideração uma variação de tempo; e a reflexão, que é a própria distinção sistemaambiente. $^{31}$

Para se relacionar com o ambiente, o sistema realiza observações e organiza seus elementos para conseguirem operar por meio de acoplamentos estruturais. Nesse contexto, todo sistema está adaptado ao seu ambiente, não de forma coordenada, mas a partir da observação do ambiente e das construções internas de sentido, levando em consideração sua própria manutenção e sobrevivência.

\footnotetext{
${ }^{31}$ Cf. Luhmann, Soziale Systeme, op. cit., pp. 600-602.
} 
Todos os sistemas realizam observações do ambiente, de outros sistemas e autoobservações, mas, para alguns sistemas, como o sistema ciência, o processo de observação e descrição de outros sistemas é o próprio código de operação interno.

Nesse processo de observação de outros sistemas, algumas das operações observadas podem ser exatamente observações realizadas pelo sistema que está sendo observado. Nesse caso ocorre uma observação de segunda ordem. A operação da observação de uma observação não pode ser nunca realizada pelo próprio sistema que opera, pois não existe sistema recursivo para diferenciar a diferença que se realiza. É o chamado ponto cego, ao que a observação de segunda ordem é uma alternativa.

O sistema pode recorrer à observação de elementos complementares à operação que realiza, ou mesmo à observação do repertório de observações possíveis e já realizadas dentro dos limites do sistema, mas isso não pressupõe uma observação de segunda ordem, pois a própria operação não pode ser observada simultaneamente à sua ocorrência.

Essa limitação afeta o conceito de racionalidade, originalmente desenvolvido dentro da teoria dos sistemas sociais, e o conceito de processo sobrecomunicativo, que este trabalho tem o objetivo de apresentar.

A observação de segunda ordem também é uma operação de um sistema e, por isso, também está condicionada pelas premissas do sistema que observa; assim, as descrições obtidas a partir da observação de segunda ordem não podem ser plenamente utilizadas pelo sistema observado, pois necessariamente devem gerar apenas um ruído que pode, ou não, ser selecionado pelo sistema observado como informação válida. Assim, mesmo que a observação de segunda ordem seja uma alternativa para o ponto cego, não é uma alternativa disponível para o sistema.

O sistema ciência especializou-se em realizar observações de segunda ordem e produzir descrições de outros sistemas ou até mesmo de si próprio, recorrendo àquele mecanismo de observação de observações já realizadas. Assim, a ciência também pode comparar diversas observações.

A observação de segunda ordem, porém, não é exclusividade do sistema científico e pode ser realizada por vários sistemas, que também podem utilizar esta observação como informação para seus respectivos processos comunicativos. 


\section{8 Racionalidade e Sentido (Rationalität, Sinn)}

A racionalidade dos sistemas sociais é a capacidade de se auto-observarem e diferenciarem a própria distinção que fazem entre sistema e ambiente. Esta capacidade é construída a partir de um mecanismo de reentrada (Re-entry) no sistema das distinções realizadas como processo gerador e constituinte de novas estruturas do sistema, agora como resultado de observação e passível de diferenciação dos elementos que constituem referências internas e dos que constituem referências externas.

A racionalidade do sistema não está embasada apenas nas operações de autoreferência, auto-observação e autopoiése, mas na capacidade do sistema de observar a autoreferência e a autopoiése em operação e utilizar esta observação auto-referencialmente. "A racionalidade do sistema significa expor à realidade e submeter à prova uma distinção: a distinção entre sistema e ambiente. ${ }^{32}$

Em certo sentido, a racionalidade pressupõe a averiguação, pelo sistem,a da repercussão dos efeitos do ambiente sobre si. Por meio da racionalidade, o sistema pode verificar quais elementos pertencem ao sistema e quais não pertencem. "Levado para a linguagem da causalidade, esta noção decreta que o sistema precisa controlar seus efeitos no ambiente pela checagem das repercussões em si mesmo se quiser experimentar a racionalidade. Um sistema que vigia seu ambiente, no final das contas, vigia a si mesmo."33

Os sistemas expressam sua racionalidade quando diferenciam, no plano das operações, o espaço interno do ambiente externo, sempre que conseguirem utilizar como informação, e portanto inicialmente irritação, suas próprias operações de diferenciação em relação ao ambiente.

Os sistemas, porém, não conseguem exercer sua racionalidade em todo momento, pois, como ela depende de uma referência e uma distinção da própria operação de distinção inicial, as operações de auto-observação possuem pontos cegos. Estes pontos cegos não podem ser observados pelo próprio observador, pois são exatamente a operação de observação sendo realizada. Essa observação da observação só é possível por um observador externo, ou observador de segunda ordem, mas nunca pela própria operação de observação no exato momento em que ocorre. “[...] nós, os observadores de segunda ordem, podemos observar o

\footnotetext{
${ }^{32}$ Luhmann \& De Georgi, Teoría de la sociedad, op. cit., p. 79.
} 
que a própria operação não consegue. O mistério encobre o ponto cego: a não-observabilidade do observador $[\ldots]]^{, 34}$

Como o próprio ato de diferenciar uma operação é uma operação, quando essa diferenciação se volta especificamente para a diferenciação que está sendo realizada ocorre um curto-circuito de operações. Uma operação não pode fazer referência a si mesma como operação ao mesmo tempo em que realiza a diferenciação.

Desse modo, a racionalidade dos sistemas não se apresenta na auto-observação (Selbstbeobachtung) e na diferenciação (Differenzierung) da própria operação de diferenciação em curso, mas na observação dos elementos do sistema aos quais aquela operação está conectada e aos quais pertencem como elementos pressupostos para a possibilidade de sua execução.

Essa pressuposição e essa referência a outras operações constituem o processo de dotação de sentido dentro dos sistemas sociais, mas também dos psíquicos.

Mais do que a racionalidade, o processo de dotação de sentido está presente em todas as operações do sistema. Para completar o processo comunicativo, o sistema necessita dotar as informações e os acontecimentos de sentido referenciando a um repertório existente e a um meio de comunicação simbolicamente generalizado. Para existir sentido é necessário um sistema que organize formas de relacionar e selecionar as informações e os processos comunicativos. A principal característica da dotação de sentido, para o sistema, é a concepção da virtualidade, ou seja, a capacidade de intelecção de que dada informação ou evento tinha outras possibilidades, outros caminhos possíveis e que, em virtude de uma seleção, outras possibilidades foram abandonadas. Esta característica envolve por um lado o reconhecimento de outras possibilidades no passado e por outro, e por isso mesmo, a manutenção de alternativas para o futuro.

Assim, o mecanismo de dotação de sentido dos processos comunicativos restringe a finalização do processo a uma compreensão, ao mesmo tempo em que também abre a possibilidade para outras operações, que se utilizam daquela como pressuposto. $\mathrm{O}$ processo de dotação de sentido também torna permanente a capacidade dos sistemas de se autoreproduzirem, na medida em que mantém como possíveis todas essas operações que fazem parte do repertório do sistema e que dão lugar a novas operações. Como um fio condutor,

\footnotetext{
${ }^{33}$ Luhmann, Soziale Systeme, op. cit., p. 642.
} 
processos comunicativos que o sistema já percorreu podem ser retomados e atualizados como alternativa possível.

Os sentidos dados pelo sistema aos processos comunicativos realizados também constituem elementos que diferenciam o sistema do ambiente e podem ser utilizados como instrumentos na auto-observação do sistema para a expressão da racionalidade. Na medida em que pontos observáveis aparecem como elementos de mesma natureza da própria operação de observação, ou seja, que ela mesma pudesse ser a operação observada.

Os sentidos dados pelos sistemas a suas operações são, ao mesmo tempo, a forma aparente dos sistemas e o elo de ligação das operações atuais dos sistemas com seu repertório e também com sistemas presentes no seu ambiente, pois lhes possibilitam ser referenciados como informação para processos de outros sistemas sociais ou psíquicos. Podemos entender o sentido como elemento com dupla função, pois estruturam internamente o sistema e podem servir de informação ou irritação para outros sistemas, portanto elementos observáveis e irritantes do ambiente de outros sistemas. Essa dupla função é importante para o entendimento posterior do conceito de acoplamento estrutural.

"Sentido habilita elementos dos sistemas sociais e psíquicos para a interpenetração, ao passo que protegem sua autopoiése; sentido habilita, simultaneamente, a consciência para entender a si mesma e para continuar a se apresenta ao processo comunicativo e o processo comunicativo para ser referido recursivamente nas consciências de seus participantes."35

O processo de dotação de sentido tem três aspectos que Luhmann caracteriza como dimensões do sentido. ${ }^{36}$ Essas dimensões têm formas de elaboração e elementos de formação próprios e geram descrições e compreensões distintas e completas, que não necessariamente podem estar relacionadas ou serem dependentes.

A primeira dimensão do sentido se refere à dimensão material, ou seja, à diferenciação entre o que tem significado e o resto dos eventos do mundo. É a seleção dos elementos que comporão o rol de informações para os processos comunicativos posteriores. Constitui a própria diferenciação entre sistema e ambiente.

A segunda dimensão é dimensão temporal, que diferencia os aspectos estruturais e os aspectos variáveis de um evento, o estado original e o estado posterior de uma estrutura após a

\footnotetext{
${ }^{34}$ Luhmann. Die Politik der Gesellschaft, op. cit., p. 379.

${ }^{35}$ Luhmann. Soziale Systeme, op. cit., p. 297.

${ }^{36}$ Cf. Luhmann, Soziale Systeme, op. cit., pp. 112 e seguintes.
} 
ocorrência de certos eventos. Esta percepção temporal gera diferenciações entre o que é e o que era e entre o que é e o que poderia ser, dada a relação de contingência dos eventos.

A terceira dimensão é a dimensão social, que diferencia os participantes de um processo comunicativo e reconhece Alter como Alter, ou seja, como participante do processo comunicativo, como endereço social para o qual se dirige este processo e como origem de processos comunicativos. Por meio da dimensão social, as expectativas de Alter são tomadas como válidas na formulação do processo comunicativo. Essa percepção leva à formação da dupla contingência, quando ambos os participantes avaliam suas expectativas e imaginam sua participação e a participação de Alter no processo comunicativo.

A diferenciação construída com o sentido e com as dimensões do sentido não é ontológica, mas relacional. Assim, os sentidos são definidos a partir de uma observação que pode tomar os eventos e as pessoas como determinantes de uma ou outra dimensão, mas em nenhum momento serão tomadas a priori como posição pré-fixada. Esta compreensão evita a aproximação da dimensão material do sentido à percepção de um objeto ou da natureza em contraponto à dimensão social à percepção de sujeitos e seres humanos. Luhmann se afasta deste modo de observação, já que a dimensão social, por exemplo, não toma Alter como sujeito ou objeto, mas como participante e endereço do processo comunicativo. 


\section{9 Evolução (Evolution)}

A teoria dos sistemas sociais inclui entre suas premissas e considerações o conceito de evolução. Este conceito, no entanto, não supõe a noção de progresso ou a existência de etapas hierarquizadas de evolução, mas sim uma composição de eventos, quais sejam seleção, transformação e reestabilização das estruturas do sistema, que aumentam a complexidade interna do sistema. ${ }^{37}$

A evolução dos sistemas, e da sociedade como sistema geral, é composta de eventos improváveis e imprevisíveis, que geram ao final do processo um ganho evolutivo indeterminável a priori. Esse ganho refere-se exclusivamente à ampliação da complexidade do sistema e à nova organização de suas estruturas.

A evolução dos sistemas não é resultado, no entanto, de um plano pré-determinado, ainda que, a certa altura da evolução sistêmica, seja tentador enxergar os sistemas como o resultado de um planejamento prévio, dada a complexidade que eles podem atingir. Isso porque os resultados das operações, de cada uma das que compõem a evolução, são imprevisíveis. Ainda que o sistema tenha atingido um grau de complexidade bastante alto e possa verificar uma certa repetição de algumas operações, cada nova operação concretizada pode levar a resultados não ocorridos antes.

Como em um jogo de xadrez, onde um bom jogador pode realizar um movimento prevendo quatro, seis, dez movimentos do oponente, dada uma lógica de movimentos de ataque e defesa razoavelmente reconhecidos como eficazes dentre os jogadores, e ainda assim, encontrar movimentos não previstos, seja por erro do adversário, seja pela adoção de uma estratégia alternativa nomeadamente menos eficaz, mas que desestabilize aquelas previsões iniciais, seja pela possibilidade de haver movimentos não previstos pelo primeiro jogador. O resultado do jogo pode ser revertido apesar de um planejamento inicial bem elaborado. A cada nova jogada alguns movimentos de ataque e defesa são impossibilitados, o que restringe o caminho para a eficácia dos movimentos do primeiro jogador, mas ao mesmo tempo novos movimentos que antes não podiam ser realizados se tornam possíveis. Neste caso a partida evolui, mas não em um sentido determinado, mas no sentido de transformar a

\footnotetext{
${ }^{37}$ Cf. Luhmann \& De Georgi, Teoría de la sociedad, op. cit., p. 214.
} 
estrutura daquela relação, neste caso um jogo de xadrez (que, aliás, pode ser compreendido como um sistema em pleno funcionamento); no nosso caso, dos elementos do sistema social.

As condições para que alguns elementos se encontrem e tornem possíveis determinada evolução são incertas e improváveis. A evolução, no entanto, restringe alguns caminhos, tornando o sistema mais previsível em alguns aspectos, ao mesmo tempo em que torna outros caminhos possíveis, reafirmando a imprevisibilidade do funcionamento do sistema. Esse processo de formação de premissas e abertura de novas possibilidades pode desencadear diferenciações internas mais consistentes, dando início, assim, à formação de outros sistemas.

Quando a complexidade de uma parcela do sistema torna-se bastante elevada e cria processos de seleção interna complexos o bastante para definir suas próprias premissas, gerar uma estabilidade relativa maior do que as outras áreas do sistema e produzir um meio de comunicação simbolicamente generalizado, ocorre a formação de um novo sistema social, que por sua vez vai iniciar seu próprio processo de produção de sentido, diferenciação entre os elementos, geração de premissas para a formação dos elementos e aumento da complexidade interna. "Na teoria dos sistemas sociais uma distinção é mais importante: a distinção entre elemento e relações, mas essa distinção pede atenção especial sobre o fato de que as relações possíveis entre os elementos aumentam em progressão geométrica quando se aumenta o número de elementos, ou seja quando o sistema cresce.”38

A evolução dos sistemas é o resultado do funcionamento de seus elementos, do crescimento da complexidade interna e da eficácia de suas diferenciações. A estabilização e a sobrevivência dos sistemas geram, progressivamente, ainda mais aumento da complexidade interna, entrando em um ciclo que resulta, muitas vezes, em uma nova diferenciação interna e na fragmentação do sistema em sub-sistemas.

Os mecanismos de acoplamento estrutural também são responsáveis por essa evolução, porque impingem ao sistema perturbações provocadas pela evolução do ambiente e também porque garantem um aproveitamento destas perturbações no processo autopoiético. ${ }^{39}$

Esse desenvolvimento está baseado nas aquisições evolutivas, que são as soluções encontradas pelos sistemas, a partir de seus próprios elementos, para as irritações externas. Essas aquisições não estão numa linha evolutiva geral, mas se relacionam com o repertório do sistema. As aquisições evolutivas, no entanto, não reconhecem hierarquias entre si nem

\footnotetext{
${ }^{38}$ Luhmann \& De Georgi, Teoría de la sociedad, op. cit., p. 60.
} 
valoração moral. A valoração é realizada dentro do sistema, de acordo com suas próprias premissas, que têm condições de verificar a validade, as vantagens e os benefícios de tomar uma decisão ou outra. Em um momento posterior, pode haver o diagnóstico que era mais vantajoso para o sistema ter continuado na situação inicial, ter realizado uma operação plena de seleção pela alternativa de manter a situação intacta frente a uma irritação ou nova informação, mas nem por isso não houve evolução. O próprio fato de o sistema poder realizar esta avaliação com mais premissas em um momento posterior o torna apto a acompanhar a evolução do ambiente.

"Esse complicado conceito de aquisição evolutiva tem em conta uma crítica dirigida a uma concepção puramente funcionalista da evolução. Não é somente a idoneidade das soluções que permite que gradualmente se encontrem soluções melhores e que estas logo se afirmem. Em referência à função sempre há um grande número de soluções possíveis: a complexidade que há ao redor delimita logo qual, dentre essas possibilidades, é mais vantajosa. Da complexidade já alcançada também depende a forma na qual se manifestam os problemas para os quais vão se perfilar as alternativas de solução (...). Com freqüência se fazem descobertas e se desenvolvem aquisições evolutivas de perspectivas falsas, ou que, de todo modo, parecem fora de lugar, ou de perspectivas relacionadas com situações que tornam acessível uma complexidade escassa. Importantes melhorias na adaptação da complexidade dos sistemas surgem da necessidade de conseguir sobreviver num ambiente que se transformou. $" 40$

Vimos, portanto, que evolução significa, antes de uma hierarquização de etapas, o aumento do número de premissas sobre as quais se apóia uma situação. Essa evolução só é possível na passagem de uma operação para outra, já que essa passagem expõe as estruturas do sistema à observação em um contexto temporal comparativo e só então é possível ao sistema incorporar novas informações e realizar uma nova decisão com um repertório maior de elementos.

\footnotetext{
${ }^{39}$ Cf. Luhmann \& De Georgi, Teoría de la sociedad, op. cit., p. 211.

${ }^{40}$ Luhmann \& De Georgi, Teoría de la sociedad, op. cit., p. 253.
} 


\section{II.10 Autopoiése (Autopoiesis)}

O processo de diferenciação sistema-ambiente produz e é possibilitado pelo funcionamento da autopoiése, um conceito importado por Luhmann da neurobiologia. A autopoiése significa a capacidade do sistema de produzir não apenas suas estruturas, como na tradição funcionalista, mas também os elementos operacionais do sistema a partir de construções internas, elaborações próprias que não têm paralelos no ambiente.

Essa noção é diferente da noção de input-output simples, desenvolvida pelas teorias funcionalistas tradicionais, pela qual os sistemas podem ter modelos e recorrências nas respostas a determinados estímulos. Ainda que nesses modelos a forma de raciocínio da "caixa-preta" esteja vedada ao exterior, ou seja, ainda que a forma que o sistema utiliza para construir suas repostas não seja conhecida, a resposta propriamente dita pode ser esperada com grandes chances de êxito, se a estrutura não estiver sobrecarregada. Na tradição funcionalista, os sistemas se auto-alimentam, mas não existe uma fronteira clara entre o que foi produzido no interior do sistema e o que do ambiente externo foi introduzido no sistema ${ }^{41}$.

A autopoiése foi utilizada por Luhmann para explicitar a independência do sistema em relação ao ambiente, que lhe possibilita o desenvolvimento de um código interno e a autoreferência. O conceito de autopoiése é foi desenvolvido inicialmente pelos neurobiólogos chilenos Humberto Maturana e Francisco Varela ${ }^{42}$, que por sua vez buscaram a base do conceito na tradicional homeostase (capacidade dos organismos de manterem sua harmonia independentemente das condições externas).

A autopoiése, como vimos, é a produção dos elementos, das estruturas e do desenvolvimento do sistema a partir de operações recursivas a outros elementos internos do sistema, que realizam seus processos comunicativos com dotação interna de sentido e utilizando um repertório próprio. A auto-referência ocorre na produção interna de sentido, mas também ocorre porque há produção interna de sentidos: porque produz internamente seus sentidos, o sistema pode realizar a auto-referência, que se consolida na próxima construção interna. A dotação interna de sentido é a chave para o desenvolvimento do sistema. E o sistema se desenvolve apenas porque em algum momento se torna capaz de realizar isso.

\footnotetext{
${ }^{41}$ Cf. Luhmann, Soziale Systeme, op. cit., p. 276.

${ }^{42}$ Cf. Luhmann, Soziale Systeme, op. cit., p. 143.
} 
Seleções internas, a partir de sentidos construídos também internamente, dão corpo para processos comunicativos e operações internas que seriam mais improváveis e contingentes no ambiente.

A autopoiése, como auto-reprodução do sistema, opera na confluência da produção interna dos elementos constitutivos do sistema, ou seja seu fechamento operacional, com sua abertura cognitiva, isto é, sua capacidade de ser estimulado pelo ambiente com informações que lhe aparecem como perturbação e irritação. Por isso as autopoiéses dos variados sistemas evoluem conjuntamente, ainda que cada uma delas se realize com os elementos constitutivos de seu respectivo sistema.

A autopoiése possibilita ao sistema alcançar uma alta complexidade interna, que serve para especificar sob quais condições os sistemas responderão às condições existentes no ambiente. Essa resposta pode significar até mesmo a absoluta indiferença. O ponto relevante, no entanto, é que o próprio sistema irá definir quais perturbações levará em consideração e quais vai considerar como subsídio para o desenvolvimento de seus processos comunicativos, além de definir como vai traduzir essas perturbações e irritações em elementos para suas operações internas na condição de informação, um dos elementos do processo comunicativo. Essa operação constitui exatamente a primeira das três operações de seleções necessárias para a concretização desse processo.

A autopoiése se aplica à reprodução das estruturas, à produção de novas estruturas, à dotação interna de sentidos, à definição do meio de comunicação simbolicamente generalizado e aos processos comunicativos. Todas as regulações internas são autoregulações, todos os controles são auto-controles. No desenho da teoria, nada pode ser reproduzido em um sistema operacionalmente fechado se não for dessa maneira.

O fechamento operacional e a autopoiése dos sistemas funcionam simultaneamente com a abertura cognitiva dos sistemas que se apropriam, a partir de formatos criados internamente, de irritações existentes no ambiente, transformadas em informações internas; com o desenvolvimento paralelo dos diversos sistemas presentes na sociedade e com uma relação muito especial entre os sistemas existentes: o acoplamento estrutural. Essa simultaneidade, sob a forma de acoplamento estrutural, constitui-se no ponto mais delicado da teoria, e também no mais refinado e complexo. 
Além da apropriação pelo sistema de informações do ambiente para o início de seu processo comunicativo interno, os sistemas sociais se relacionam com outros sistemas, sociais e psíquicos, existentes em seu ambiente, por meio do mecanismo de acoplamento estrutural, que lhes permite operar seus processos comunicativos utilizando as estruturas de outros sistemas sociais. 


\section{III - RELAÇÕES INTER-SISTÊMICAS}

\section{1 Acoplamento Estrutural (strukturelle Kopplung)}

Sistemas sociais podem se relacionar seja com os elementos do seu ambiente, seja com outros sistemas sociais ou psíquicos, através de um mecanismo ao mesmo tempo superficial e complexo denominado acoplamento estrutural, por meio do qual um sistema utiliza as estruturas de funcionamento de outro sistema. Por este mecanismo, um sistema utiliza os elementos de outro para operar os seus próprios processos comunicativos. O conceito não existia no esboço inicial da teoria, apresentado em Soziale Systeme. ${ }^{43}$ Até então, Luhmann utilizava o termo interpenetração, originário da teoria parsoniana, para designar todas as relações inter-sistêmicas. A partir de Die Wissenschaft der Gesellschaft, o conceito de acoplamento estrutural passa a ser utilizado para designar as relações inter-sistêmicas em geral e o termo interpenetração passa a designar um caso específico. ${ }^{44}$

Quando há um acoplamento estrutural, o processo comunicativo de um sistema aparece no outro não apenas como uma perturbação, mas também como uma ferramenta auxiliar de funcionamento das operações; seu significado, no entanto, vai ser construído apenas dentro do próprio sistema em que foi realizado o processo comunicativo, de forma independente do significado que tinha naquele sistema original. Apenas a complexidade operacional de um sistema do ambiente é reproduzida dentro do sistema que realiza o processo comunicativo, não seus processos de cognição. Esse é o caso, por exemplo, das estruturas lingüísticas que são utilizadas para realizar algumas atividades comunicativas,

\footnotetext{
${ }^{43}$ O conceito, no entanto, já começa a ser delineado neste livro, de 1984, quando Luhmann discute a noção de estrutura (p.387): “Assim, as características que predominantemente definem o conceito de estrutura (da qual a multiplicidade deixou inicialmente a impressão de um conceito pouco claro e controverso) foram trazidas ao denominador comum da seleção de uma limitação. Apenas a contingência relacionada a isto dá valor estrutural à uma relação entre elementos - e isto vale tanto para o plano dos sistemas que se reproduzem realmente como para o plano de suas descrições."(grifos nossos). Em Recht der Gesellschaft (1995) e em Politik der Gesellschaft (2002), o conceito de acoplamento estrutural passa a receber atenção especial e se constitui em um capítulo à parte, substituindo o conceito de interpenetração como designador do caso geral de relações inter-sistêmicas. A tradução do capítulo do livro Die Politik der Gesellschaft referente a este tema compõe o presente trabalho, na condição de anexo.

44 A partir deste livro, de 1992, o termo interpenetração designa a relação entre sistemas sociais e sistemas psíquicos. O conceito paulatinamente perde espaço nas descrições da teoria, mas, mesmo na síntese final do desenho da teoria, Die Gesellschaft der Gesellschaft (1998), Luhmann faz remissão ao conceito apresentado em Soziale Systeme para designar as relações entre sistemas psíquicos e sistemas sociais.
} 
dentro de um sistema com lógicas próprias, como no exemplo dado acima das operações financeiras.

Pelo acoplamento estrutural um sistema "empresta" de um outro sistema, que é visto como parte do ambiente daquele primeiro, as estruturas necessárias para realizar as suas próprias operações.

As estruturas externas ao sistema são utilizadas como condutores dos processos comunicativos e, para isso, o sistema que toma emprestado as estruturas não precisa conhecer a forma de organização interna do sistema que lhe empresta a estrutura. A relação é meramente funcional: os processos de dotação de sentido, de formação de repertório de processos comunicativos e operações internas são isolados e inacessíveis de um ao outro.

Isso ocorre porque o código utilizado por um sistema é totalmente diverso e ininteligível para os outros sistemas. Isso alça o processo comunicativo a um plano central no esclarecimento da diferenciação sistema-ambiente e da continuidade e complementaridade entre ambos. Como são os processos comunicativos internos, a partir dos quais os códigos binários próprios podem desenvolver-se, que diferenciam os sistemas, é exatamente essa distinção que é preservada no mecanismo do acoplamento estrutural.

Em muitos casos, o acoplamento estrutural é responsável por perturbações e irritações para o sistema, porque, além de as estruturas de outro sistema funcionarem como elemento de apoio às operações do sistema, elas aparecem também como informação desorganizada e presente em seu ambiente. Assim, o acoplamento estrutural é um dos elos de ligação do sistema ao seu ambiente. "Todos os sistemas precisam de muitos pressupostos fáticos em seu ambiente, que não podem produzir nem garantir por eles mesmos, um 'continuum de materialidade' necessário para sua existência." ${ }^{45}$ Dessa forma, o acoplamento estrutural e os sistemas acoplados são necessários para a existência dos vários sistemas: a existência dos sistemas psíquicos são condição necessária para a existência dos sistemas sociais, assim como o sistema biológico é condição necessária para a existência dos sistemas psíquicos e viceversa.

Como a teoria parte do princípio do fechamento operacional, esse desenvolvimento totalmente autônomo do sistema em relação ao ambiente, simultâneo a uma atenção do sistema sobre o ambiente, é um dos elementos de geração de conflitos e desestabilizações dos

\footnotetext{
${ }^{45}$ Baraldi, Corsi \& Esposito, Glossar, op. cit., p.186.
} 
sistemas. Essas desestabilizações, no entanto, não são prejudiciais para os sistemas, ao contrário, auxiliam seu desenvolvimento: "Sistemas complexos requerem um alto grau de instabilidade para permitir uma reação continuada a si próprios e a seus ambientes, e eles precisam reproduzir continuamente esta instabilidade." 46

Os sistemas já consolidados conseguem lidar com mais desenvoltura com o seu ambiente porque não correm mais o risco de sofrerem ingerências externas em seus processos comunicativos internos. Por isso, esses sistemas estão mais abertos ao contato com essas irritações do ambiente, que podem, assim, ser internalizadas como auto-irritação e, conseqüentemente, como informação auto-selecionada. No raio de ação de seus elementos constitutivos, esses sistemas consolidados têm a possibilidade de funcionar de forma totalmente diversa de seu ambiente e, ao mesmo tempo, utilizar estruturas externas para o mecanismo do acoplamento estrutural e informações do ambiente como elemento de seus processo comunicativos.

O acoplamento estrutural permanece invisível para o sistema, pois não pode contribuir com a produção de seus elementos, ${ }^{47}$ e ele pode ocorrer sem que o sistema perceba. Pode ocorrer sem a necessidade de reflexão ou de observação por nenhum dos sistemas. Os sistemas funcionam relacionados sem que se note, sem visibilidade, e este é um dos motivos pelos quais a compreensão do conceito de acoplamento estrutural é mais difícil.

Pelo acoplamento estrutural um sistema pode se relacionar com sistemas altamente complexos do ambiente que o envolve, sem que precise alcançar ou reconstruir cognitivamente sua complexidade, mas apenas operacionalmente relacionar-se com os elementos do outro sistema, a fim de colocar em operação seus próprios elementos. Assim, um sistema pode utilizar estruturas mais avançadas do que as suas próprias sem a necessidade de compreender as suas lógicas de funcionamento.

Uma exemplificação da situação na qual um sistema não precisa conhecer o modo de operação de outro para utilizar seus elementos é o reconhecimento da possibilidade de utilização de máquinas eletrônicas pelos sistemas psíquicos sem um prévio conhecimento das operações internas daquele sistema, que podem, sem prejudicar sua operacionalidade, permanecer obscuras ao sistema psíquico. É o que ocorre quando utilizamos uma calculadora para realizar algumas operações matemáticas: entramos com os dados, pedimos e recebemos o

${ }^{46}$ Luhmann, Soziale Systeme, op. cit., p. 501. 
resultado, mas não sabemos como os eletrodos e chips realizaram internamente as operações. $^{48}$

Outra modo de exemplificar o funcionamento do acoplamento estrutural é partindo da análise do acoplamento entre o sistema política e o sistema direito na elaboração das leis, no processo legislativo. Por um lado, a elaboração das leis é um processo político, que envolve as decisões de poder, a votação de determinações que vinculam toda a população que pertence àquela jurisdição política. Esse processo, no entanto, utiliza e obedece a certos parâmetros legais (que um dia já passaram pelo processo político) e pode ser questionado com base em códigos jurídicos que estão fora do escopo de atuação da política. Os legisladores não precisam ser bacharéis em direito para representar a população nas votações das leis, ou seja, o sistema político não precisa compreender a complexidade do sistema jurídico para realizar suas operações, no máximo precisa conhecer algumas limitações que podem gerar sanções e eliminar a comunicação do sistema político.

De modo geral, o sistema político não precisa conhecer alei eleitoral para que os políticos façam campanha eleitoral, não precisam conhecer todas as normas de processo constitucional para votarem uma emenda constitucional e não precisam conhecer direito administrativo para nomear correligionários para os cargos em confiança que dispõem em seus mandatos.

$\mathrm{O}$ acoplamento estrutural tem um papel importante no processo de evolução de um sistema, já que lhe impinge perturbações freqüentes provocadas pela evolução do ambiente acoplado, que admite e estimula indiretamente a evolução do sistema. Esses ruídos são produzidos e, ambos os lados do acoplamento e, no caso de dois sistemas acoplados, essas irritações mútuas geram um fluxo estrutural e ocasionam a evolução recíproca, com a produção de informações para ambos os sistemas, pois, apesar de autopoiéticos, ambos podem observar os sentidos produzidos em uma mesma ocorrência no âmbito do acoplamento.

${ }^{47}$ Cf. Luhmann, Die Politik der Gesellschaft, op. cit., p. 375.

${ }^{48}$ Vale ressaltar que o exemplo apresentado não trata de um acoplamento estrutural, mas de um acoplamento operacional, que funciona sob a mesma base, mas não envolve uma relação de necessidade, que aparece nos acoplamentos estruturais. A operação com a calculadora é um acoplamento efêmero, que pode desfazer-se facilmente sem prejuízo das operações essenciais de ambos os sistemas. Estes acoplamentos temporários diferenciados dos acoplamentos estruturais, no entanto, também são importantes para o desenvolvimento dos sistemas, já que possibilitam o processamento temporal das operações do sistema, gerando uma estabilidade dinâmica e possibilitando a autopoiése a partir de informações externas. Cf . Luhmann, Die Gesellschaft der Gesellschaft, op. cit. p. 199. 
Esse fluxo, no entanto, é assumido como parte dos processos comunicativos próprios do sistema: "Nada pode ser estipulado do exterior por meio de uma decisão e, apesar disto, a organização, por meio de seu ambiente, segue uma irritação constante e um fluxo estrutural, que na rede recursiva das próprias operações é reconhecida como restrição autoselecionada". 49

Assim, ainda que os sistemas operem com seus próprios elementos, não seria razoável supor que sistemas totalmente anacrônicos pudessem sobreviver por muito tempo, de acordo com o entendimento de acoplamento estrutural.

Além disso, o acoplamento estrutural pode ser o suporte do funcionamento dos processos comunicativos de um sistema acoplado. Isto não significa, no entanto, que o acoplamento, seu funcionamento ou mesmo sua suspensão possam determinar as variações internas dos processos comunicativos. Assim, é possível que a suspensão de um acoplamento estrutural encerre os processos comunicativos dentro de um sistema, talvez até fazendo desaparecer aquele sistema; esse mesmo acoplamento estrutural, no entanto, não tem competência para definir o modo de funcionamento interno do sistema em questão. "O não funcionamento do acoplamento estrutural pode apenas interromper o processo comunicativo ou eventualmente terminá-lo, mas não pode jamais levar a perturbações nestes processos comunicativos, as quais podem ser remediadas ou transformadas em formas menos irritantes apenas mediante outros processos comunicativos internos, portanto autopoieticamente." 50

Assim, sem o acoplamento entre o cérebro (sistema biológico) e a consciência (sistema psíquico), esta última não poderia existir, ainda que, quando esteja em operação, não leva em consideração o funcionamento das sinapses para gerenciar seus elementos internos, neste caso os pensamentos. Da mesma maneira, um sistema social precisa necessariamente estar acoplado às consciências (sistemas psíquicos) para operar, ao mesmo tempo em que não precisa levar em consideração os elementos desta última (pensamentos) para realizar suas operações, ou seja, processos comunicativos.

A leitura interna do acoplamento estrutural pelo sistema pode ocorrer por meio do reconhecimento de irritações ou perturbações, que surgem do confronto interno de expectativas intra-sistêmicas com os acontecimentos e perturbações externos.

\footnotetext{
${ }^{49}$ Luhmann, Die Politik der Gesellschaft, op. cit., p. 397.

${ }^{50}$ Luhmann, Die Politik der Gesellschaft, op. cit., p. 374.
} 
Não se trata, portanto, de transferências de perturbações do ambiente para o sistema, mas de auto-irritações, que são relações com as expectativas do sistema, ainda que posteriores a influxos causadores de irritação do ambiente acoplado.

O sistema encontra na sua própria rede recursiva as maneiras de tratar aquela irritação e de produzir um processo comunicativo a partir dela, ou mesmo de ignorar aquela irritação e não selecioná-la como informação válida. Esta possibilidade está colocada na capacidade de distinção, própria do sistema, entre auto-referência e elementos externos, que gera um processo cognitivo e um processo comunicativo a partir de irritações externas, mas com a construção interna de elementos do sistema.

Essa irritação causada pelo acoplamento estrutural, no entanto, pode ser significativa para dois sistemas acoplados. Isto pode ocorrer exatamente porque cada um dos sistemas realiza suas próprias seleções internas de dotação de sentido daquela irritação, transformandoa em uma auto-irritação e uma informação, em sistemas com diferentes repertórios, portanto de forma totalmente diferente. Essa dupla utilização por sistemas diferentes, no entanto, não prejudica a diferenciação entre os sistemas. ${ }^{51}$ Dessa forma, podem haver instrumentos que tenham relevância simultânea no sistema político e no econômico, como a definição dos impostos ou da taxa de juros, ou no sistema religioso e político, como a eleição de um padre para a câmara de vereadores, entre outros.

No processo histórico, a organização da informação perdida e desorganizada do ambiente leva a um desenvolvimento interno do sistema por sucessivos processos comunicativos, que aumentam a complexidade interna do sistema. A dotação de sentido pelos sistemas é umas das variantes desse desenvolvimento e essa dotação de sentido é uma operação interna; portanto as irritações externas precisam do filtro interno para serem utilizadas neste processo.

Este desenvolvimento, que torna o sistema internamente mais complexo ao mesmo tempo em que marca sua diferença com o ambiente, gerou a necessidade de os sistemas desenvolverem uma forma de relacionamento com o ambiente. $\mathrm{O}$ acoplamento estrutural, desta maneira, pode ser compreendido como uma necessidade advinda da diferença funcional dos sistemas. Essa diferenciação inicial, que foi responsável pela gênese do sistema, necessita de um mecanismo para, ao mesmo tempo em que promove a delimitação de suas fronteiras,

\footnotetext{
${ }^{51}$ Baraldi, Corsi \& Espósito, Glossar, op. cit., p.186.
} 
manter a relação com o ambiente à sua volta, tanto para poder utilizar estruturas que não formam seus elementos de operação mas são necessários para que eles operem, quanto para garantir a apropriação de elementos do ambiente como informação e a evolução conjunta das estruturas do sistema e do ambiente.

Dentre o conjunto de acoplamentos estruturais nos quais o sistema participa, existem alguns que são mais significativos para seu funcionamento, que produzem mais irritação, com uma freqüência maior e que são mais selecionados para serem utilizados como informação no processo comunicativo interno. Estes acoplamentos são responsáveis por um fluxo estrutural e por uma parcela da evolução do sistema. Sob este aspecto, estes acoplamentos podem se desenvolver como sistemas autônomos, sobretudo como sistemas de organização. O acoplamento estrutural, neste caso, pode ao mesmo tempo "desenvolver a liberdade do sistema associado e construir sua própria complexidade". ${ }^{52}$

O desenvolvimento de um novo sistema pelo processo de diferenciação sistêmica destes acoplamentos estruturais não é, no entanto, nem certo nem necessário, no sentido de ser antevisto, já que os sistemas podem gerar continuamente elementos que limitem o desenvolvimento da complexidade daquele acoplamento independetemente da freqüência em que ele gere as irritações. Podemos exemplificar este caso, novamente com o acoplamento entre o sistema jurídico e o sistema político ${ }^{53}$. Neste acoplamento, apesar de se ter desenvolvido como uma estrutura muito forte na figura de "Estado", as irritações mútuas são freqüentes, duradouras e geram bastante informação em ambos os sistemas. Não obstante, tanto o sistema jurídico quanto o sistema político resguardam suas respectivas autonomias criando reservas de significação e atuação, gerando autopoieticamente os elementos internos a partir daquela irritação advinda do ruidoso "Estado". O acoplamento estrutural não limita, por mais ruidoso que seja, a autopoiése do sistema.

Esses ruídos gerados nos acoplamentos estruturais podem alimentar indefinidamente a ambos os sistemas, em um processo que se concretiza na captação pelo sistema do ruído do ambiente seguida da dotação de sentido e realização de um processo comunicativo interno, que gera um ruído para o outro sistema acoplado, que repete o processo, agora sob o ponto de vista de suas premissas e, assim sucessivamente.

\footnotetext{
${ }^{52}$ Luhmann. Die Politik der Gesellschaft, op. cit., p. 382.

${ }^{53}$ Cf. Luhmann. Die Politik der Gesellschaft, op. cit., p. 388-392
} 
Segundo a teoria dos sistemas sociais, essa irritação mútua não é calculável, ou pelo menos o processo não oferece garantia nenhuma de que a dotação do sentido por um dos sistemas acoplados possa ser previamente conhecido pelo outro.

Os acoplamentos estruturais podem ocorrer entre sistemas sociais, como no caso dos sistema político e jurídico, mas também podem ocorrer entre outros sistemas. Além dos acoplamentos estruturais, relações inter-sistêmicas entre sistemas sociais e sistemas psíquicos e entre sistemas psíquicos interessam particularmente à teoria dos sistemas sociais. 


\section{2 Interpenetrações (Interpenetrationen)}

O acoplamento estrutural específico entre sistemas psíquicos e sistemas sociais é um caso especial e recebe o nome de interpenetração (Interpenetration). ${ }^{54}$ Para esta dissertação, a análise deste tipo de acoplamento estrutural tem especial interesse, porque ela fornece subsídios para a análise das relações inter-sistêmicas a partir da observação da pessoa como destinatário privilegiado de processos comunicativos, principalmente em relações de acoplamentos estruturais entre dois sistemas sociais.

A noção inicial desta relação advém diretamente da diferenciação inicial da teoria dos sistemas: as pessoas não são parte da sociedade (Gesellschaft), constituem-se em sistemas autopoiéticos e auto-referenciais independentes (os sistemas psíquicos).

Nas relações de interpenetração entre sistemas psíquicos e sistemas sociais, a consciência é necessária para a existência do processo comunicativo, mas a consciência não é nem o sujeito nem o substrato do processo comunicativo. A consciência é o campo de atuação e os limites do sistema psíquico e nenhum outro sistema, reciprocamente, tem preeminência sobre suas operações e estruturas internas, os pensamentos.

A consciência é a forma constitutiva dos sistemas psíquicos, em substituição ao conceito tradicional de indivíduo. A consciência só pode ser desenvolvida a partir de elementos internos do próprio sistema: os pensamentos. Isso quer dizer também que esses elementos só operam internamente, nunca em processos comunicativos. "Eles [os sistemas psíquicos] utilizam a consciência somente no contexto de suas próprias operações." ${ }^{\text {,5 }}$

Pensamentos não comunicam, porém, tanto a consciência é indispensável ao processo comunicativo como fonte de perturbação e irritação, como dá suporte ao processo comunicativo. E o processo comunicativo é indispensável à consciência, que, sem ele, não poderia ultrapassar os limites do sistema psíquico original, prejudicando suas possibilidades

54 O estudo deste conceito causa muita confusão entre os pesquisadores, já que Luhmann trata de interpenetrações - conceito emprestado do arcabouço teórico parsoniano - apenas nas primeiras obras em que apresenta o esboço da teoria, por exemplo, Liebe als Passion. Zur Codierung von Intimitä (Amor como paixão: para a codificação da intimidade), de 1982, e Soziale Systeme, de 1984. Neste livro, o termo é utilizado para designar todas as relações inter-sistêmicas, mas Luhmann o substitui nas obras seguintes pelo conceito de acoplamento estrutural. Como a menção ao termo nas obras de Luhmann foi rareando com o passar do tempo, alguns autores tenderam a considerar o conceito extinto; já outros, que se tinham formado a partir da leitura de Soziale Systeme tenderam a ampliar o conceito para todas as relações inter-sistêmicas. O correto, neste caso, é assumir a posição do próprio Luhmann, que defende a especificidade do conceito de interpenetração em Die Gesellschaft der Gesellschaft, op. cit., p. 378. 
de evolução e aquisições cognitivas. Esse processo é possível, ainda que cada sistema receba as comunicações dos outros sistemas apenas como perturbações e realize internamente sua dotação de sentido.

Ainda assim, por via do acoplamento estrutural, a relação de interpenetração é necessária e resulta no desenvolvimento mútuo dos sistemas, não no sentido de integração social, mas de aumento da complexidade interna de ambos os sistemas. "O conceito de interpenetração não indica apenas uma intersecção de elementos, mas uma contribuição mútua para uma constituição seletiva desses elementos que levam a tal intersecção."

Essa relação ocorre quando ambos colocam e dispõem, mutuamente, da complexidade estrutural do outro para realizar suas próprias operações. Esse mecanismo aumenta o número de possibilidades de processos comunicativos, no caso do sistema social, e de pensamentos, no caso do sistema psíquico. Essa maior gama de alternativas significa, ao mesmo tempo, pressão sobre a seleção e liberdade de escolha.

Como esta relação é uma relação de acoplamento estrutural, cada um dos sistemas permanece como ambiente do outro e um representa para o outro, ao mesmo tempo, um suporte de estrutura e um conjunto de perturbações e desordem. Estas perturbações constituem-se em ruído para um e para outro, que por sua vez vão constituir elementos a serem trabalhados internamente por meio da auto-referência, com relação à referência externa. Esses ruídos e perturbações poderão ser traduzidos, em cada um dos sistemas, como informações e fornecer subsídios para operações internas. Essa irritação mútua possibilita a evolução dos sistemas.

Outras distinções, e simultâneos acoplamentos estruturais, também são possíveis no processo de formação da consciência; por exemplo, os acoplamentos entre o cérebro ou massa encefálica (como sistema biológico) e a consciência (como sistema psíquico). Ambos reconhecendo mutuamente as diferenças e estabelecendo, portanto, a distinção, que permite desenvolver ainda mais os elementos internos de cada um.

\footnotetext{
${ }^{55}$ Luhmann, Soziale Systeme, op. cit., p. 355.

${ }^{56}$ Luhmann, Soziale Systeme, op. cit., pp. 292-293.
} 


\section{III.3 Organizações (Organisationen)}

Outro caso de acoplamentos estruturais que interessam especialmente à teoria e também ao propósito desta dissertação é o que leva à formação das organizações.

As organizações são um tipo de sistema social que não desenvolve um código de comunicação próprio, mas que se diferencia com a utilização de outro critério: o do pertencimento. Assim, não é possível haver descrições diferentes dos limites deste sistema, já que a abrangência dele é expressa nas categorias membro e não-membro. Como exemplo de organizações, temos os partidos políticos, as escolas, as universidades, os tribunais de justiça, entre outros. Nestes sistemas, a identificação de membros e não-membros é imediata.

Este sistema organizacional desenvolve processos comunicativos que têm significado em mais de um sistema funcional consolidado, como ocorre com os processos de acoplamento estrutural. Assim, apesar de, na maioria dos $\operatorname{casos}^{57}$, serem estruturas reconhecidamente vinculadas a um determinado sistema funcional - os partidos operam claramente no sistema político, as universidades, no sistema ciência e os tribunais, no sistema direito -, as organizações têm relevância também para outros sistemas consolidados - as doações aos partidos têm relevância no sistema economia; os diplomas concedidos na universidade têm relevância no sistema economia; as decisões judiciais proferidas no tribunal têm relevância nos sistemas nos quais o processos julgados tiveram origem, seja o sistema econômico, o sistema família, ou qualquer outro. O processo comunicativo no sistema organizacional têm dupla referência semântica. Nos sistemas organizacionais, o acoplamento estrutural entre diversos sistemas é parte integrante das próprias operações do sistema e, por conseguinte, as organizações não podem ser compostas de processos comunicativos de um único sistema social. Os sistemas organizacionais, no entanto, não podem preencher todo o potencial funcional de nenhum dos sistemas sociais - economia, ciência, política, etc. - acoplados.

Os processos comunicativos levados a cabo no sistema organizacional obedecem regras de funcionamento próprias, apesar de não serem elaborados a partir de um código próprio - o código utilizado, na maioria dos casos, é o mesmo que o utilizado no sistema funcional ascendente, ou seja, a oposição validade/não validade da teoria no caso da

\footnotetext{
57 Sistemas organização, no entanto, podem aparecer sem necessariamente ter vinculação a sistemas sociais ascendentes, vinculando-se diretamente à complexidade da sociedade, como associações voluntárias. Cf. Luhmann \& De Georgi, Teoría de la Sociedad, op. cit., p. 370.
} 
universidade, a oposição poder/não poder no caso do partido político e a oposição legal/ilegal no caso dos tribunais.

Nos sistemas organizacionais, a elaboração dos processso comunicativos não é referida apenas ao código, mas também às vias de comunicação (Kommunikationswege), construídas com base na estrutura hierárquica da organização, que estabelece as posições e a diferenciação interna do sistema organizacional ${ }^{58}$. A determinação da temporalidade e o controle da freqüência ${ }^{59}$ dos processos comunicativos dentro dos sistema ascendentes também é uma característica importante na estruturação dos sistemas organizacionais, pois lhes confere, muitas vezes, uma função importante para a reprodução do sistema funcional ascendente.

Outra característica importante nos sistemas organizacionais é a existência de programas, que estabelecem tanto os objetivos e metas do referido sistema quanto as condições nas quais estas metas têm de ser atingidas. O estabelecimento desses programas determina os limites de atuação dos membros das organizações, o rol de decisões que estão sob a responsabilidade de cada um dos membros, o modo de ascensão dentro da hierarquia da organização, entre outros aspectos de seu funcionamento. Estas definições criam as vias por onde os processos comunicativos podem ser canalizados - como a linguagem, essas vias constituem um meio para a ocorrência do processo comunicativo.

A identidade da organização é determinada então por estas três características: os membros que ocupam os cargos dentro da organização, os programas e as vias de comunicação criadas por estas combinações. Em outras palavras, a organização está estruturada em posições, que são ocupadas por membros determinados, que tem funções definidas e tarefas. Estas posições são a expressão da redução de complexidade do ambiente pelo sistema organizacional. Os elementos que forma esta posição podem ser alterados, sem que a organização perca sua eficiência. Assim, podem ser alteradas as pessoas que ocupam estas posições e mesmo as funções de determinadas posições, pois o sistema continuará em operação.

Essa continuidade, perseguida por todos os sistemas funcionais, se caracteriza pela elaboração de premissas para as comunicações seguintes dentro do sistema organizacional, como todos os outros sistemas sociais. Nas organizações, no entanto, as vias de comunicação

${ }^{58}$ Baraldi, Corsi \& Espósito, Glossar, op. cit., pp.129 e seguintes. 
estão fortemente determinadas, o que muitas vezes pode levar o observador externo a não compreender a lógica conservadora que pode gerir o funcionamento das organizações, com a realização de processos comunicativos muito mais focados em satisfazer as expectativas do próprio sistema organização do que aos sistemas sociais que lhes deram origem.

Paradoxalmente, as organizações podem ser as guardiãs de alguns processos comunicativos essenciais para o sistema ascendente, mesmo tendo esses processo comunicativos sentidos e relevância em outros sistemas por conta do acoplamento estrutural.

É assim, por exemplo, com as organizações igrejas, para o sistema religião, universidade, para o sistema ciência, e partidos, para o sistema política: processos comunicativos essenciais dos sistemas ascendentes, o culto e a pregação, na igreja, a experiência e o exame de validade, na universidade, as convenções e as disputas, nos partidos, têm relevância não apenas no sistema ascendente, mas também em sistemas acoplados. $\mathrm{O}$ pastor bem articulado pode estar angariando poder político a ser transformado em um mandato no parlamento nas próximas eleições; o aluno aplicado pode estar angariando prestígio junto a um empregador potencial com os resultados de um experimento científico; e o candidato pode estar vislumbrando uma melhor remuneração do que a recebida em seu emprego ordinário. A relevância das realizações da organização, reconhecidas como parte dos sistemas sociais ascendentes, confere mais autonomia e legitimidade à autopoiése destes sistemas no conjunto da sociedade.

Por conta destas possibilidades, o conceito de organização será útil no entendimento do conceito de processos sobrecomunicativos. O próprio Luhmann aponta esta direção ao afirmar que "para poder reconhecer a função das organizações na construção de uma sociedade funcionalmente diferenciada é preciso lembrar que as organizações são os únicos sistemas sociais que podem se comunicar com os sistemas de seu ambiente" ${ }^{, 60}$. Apesar de Luhmann determinar que entre sistemas sociais como a economia ou a política não há interferências inter-sistêmicas, o reconhecimento de que as comunicações inter-sistêmicas são possíveis, pelo menos por meio das organizações, reforça a necessidade de uma proposição de conceitualização destas interferências. A hipótese é a de que o fenômeno é mais abrangente do que propõe Luhmann nessa passagem.

\footnotetext{
${ }^{59}$ Cf. Luhmann, Die Wissenschaft der Gesellschaft, op. cit., 1992, p. 337.

${ }^{60}$ Luhmann, Die Gesellschaft der Gesellschaft, op. cit. pp. 842-843.
} 


\section{4 Interações (Interaktionen)}

Além das interpenetrações, há outra forma de relações inter-sistêmicas que levam em consideração a participação de pessoas: a interação. Nesse caso, no entanto, o conceito está relacionado especificamente com os processos comunicativos que envolvem as relações diretas, ou presenciais, entre os sistemas psíquicos. As interações podem ocorrer no interior de sistemas sociais, mas também podem ocorrer prescindindo da existência de um sistema consolidado. Nesse caso, pode ser formado um sistema social efêmero, cujos processos comunicativos não estão inseridos em nenhum sistema funcional e cujos efeitos não formaram necessariamente premissas de novos processos comunicativos.

As interações são sistemas sociais caracterizados pela presença física dos participantes; essa é sua característica diferenciadora. Quando as interações ocorrem no âmbito dos processos comunicativos de um sistema social, ou no âmbito de uma organizações, as pessoas exercem duplo papel: um na relação de interação em que tomam parte e outro no sistema social na qual aquela interação toma parte. "Exatamente porque as pessoas sabem como manejar essa diferenciação a sociedade pode emergir da interação." ${ }^{\prime 1}$

Essa diferenciação é relevante porque a interação pode ser fator de perturbação para o sistema social em cujo âmbito ocorreu aquela interação. Assim como o sistema social onde ocorreu a interação pode ser um fator de perturbação para esta.

A percepção de um pressupõe o processo comunicativo na interação, já que Ego toma como certo que sua operação gera significados para Alter, e mesmo o silêncio gera significado neste aspecto - pelo menos o da falta de estímulo para o início do processo comunicativo. "A percepção obriga a comunicação: quem percebe que é percebido e percebe que sua percepção é por sua vez percebida não pode fazer outra coisa se não observar que seu comportamento será tomado como informação no processo comunicativo." 62

Apesar de uma interação poder ocorrer no âmbito de um sistema social consolidado, os processos comunicativos dessa interação podem não pertencer ao sistema social ou à organização que ensejou aquela interação, pois os sistemas se diferenciam pela forma de processos comunicativos. As interações, apesar de constituírem sistemas sociais simples, à

\footnotetext{
${ }^{61}$ Luhmann, Soziale Systeme, op. cit., p.405.

${ }^{62}$ Baraldi, Corsi \& Espósito, Glossar, op. cit., p.82.
} 
medida que envolvem apenas a diferenciação entre presentes e ausentes, podem gerar seleções bastante complexas.

Estas seleções podem ocorrer nos diferentes níveis da dimensão do sentido, na identificação do interlocutor, na identificação da temporalidade da interação e na identificação da atuação na interação. A interação constitui o nível mínimo de elaboração de processos comunicativos e possui obviamente muitos limites de alcance - como a impossibilidade de agrupar muitos participantes ativos ao mesmo tempo e com isso obter processos comunicativos mais complexos, ou mesmo o risco de processos comunicativos conflituosos ou de pouco interesse levarem ao fim da interação, pelo abandono da interação por uma ou mais partes. Mesmo assim, as interações se constituem em âmbitos válidos de formação de processos comunicativos e de geração de sentido.

Dessa forma, ainda que as interações possam ter uma forma bastante simples de diferenciação (a oposição presente/ausente) e se apresentar em contextos fora do âmbito de sistemas complexos, são produzidos sentidos, significados e os processos comunicativos ocorrem com todas as suas etapas de seleção. A utilização destes sentidos como premissas para a elaboração de processos comunicativos posteriores dependerá da existência de um sistema social ascendente ou mesmo da formação de um sistema social duradouro a partir daquela interação, por exemplo, a formação de um sistema de relações íntimas.

No caso da simultaneidade entre um processo comunicativo em um sistema interacional efêmero - ou em um sistema social de relações íntimas em formação - e um processo comunicativo em um sistema social consolidado, há uma intersecção de elementos dos processos comunicativos. Ambos processos comunicativos podem estar ocorrendo com a utilização, inclusive de elementos em comum, mas que geram significados diferentes nos diferentes sistemas para os quais são relevantes.

Essa intersecção é um dos pontos mais frágeis do fechamento operacional dos sistemas, pois ocorrem simultaneamente uma interpenetração, uma interação e os processos comunicativos próprios de cada um dos sistemas envolvidos. Nesse momento, este tipo de ocorrência gera, como os acoplamentos estruturais, dupla significação e abre espaço para a possibilidade de influência da estrutura e dos sentidos de um sistema sobre o outro, como veremos no capítulo seguinte. 


\section{IV - INTERFERÊNCIAS EXTERNAS NO SISTEMA}

\section{IV.1 Alopoiése (Allopoiesis) - Sistemas de fechamento operacional incompleto}

Como vimos, os sistemas sociais complexos e consolidados funcionam autopoieticamente e fechados operacionalmente, ou seja, produzem seus próprios elementos de operação a partir de operações recursivas ao repertório de operações já existentes de dentro do sistema e não admitem dentro de seus limites e fronteiras interferências de operações externas.

As operações próprias dos sistemas sociais são os processos comunicativos, que são formados por três elementos independentes e complementares: a informação, a participação e a compreensão. Dos três elementos, a informação é a única que pode ser gerada no ambiente, primeiramente como irritação e perturbação, que pode ser apropriada pelo sistema a partir de uma seleção do próprio sistema, antes de colocar em operação os outros elementos do processo comunicativo. Esse mecanismo é o que garante ao sistema a abertura cognitiva simultânea ao fechamento operacional.

É exatamente o fechamento operacional que dá ao sistema a possibilidade de se desenvolver e evoluir, à medida que lhe permite operar autonomamente e direcionar suas operações com as informações existentes no exterior, que seleciona como válidas. Dado que o funcionamento dos sistemas sociais é dinâmico, nada garante que um sistema autopoiético e operacionalmente fechado, portanto consolidado, continuará existindo no instante seguinte. Os sistemas operam constantemente para manter essa sobrevivência e autonomia por meio da constante diferenciação com o ambiente e da manutenção da distinção de seus processos comunicativos e de seus códigos internos, ou meios de comunicação simbolicamente generalizados.

Além disso, nem todos os sistemas estão consolidados. Alguns sistemas são extremamente efêmeros e outros ainda estão em fase de consolidação, com a definição de seus processos comunicativos internos, de seu código de operação e de seu meio de comunicação simbolicamente generalizado. Alguns desses sistemas, no entanto, apresentam algumas características de sistemas consolidados, apesar de ainda estarem em fase de consolidação. Assim, alguns deles apresentam um grau bastante acentuado de resistência a alguns tipos de 
influências externas - podendo fazer sugerir que atingiram um grau de diferenciação funcional pleno -, mas não a outros - o que denuncia a precariedade de seus limites em relação ao ambiente.

Este é o caso de sistemas sociais que ainda não atingiram seu completo fechamento operacional. Esses sistemas mantém alguma conexão entre os elementos internos, mas estão incompletos, ainda que possam apresentar também a existência de um código explícito, formas pré-estabelecidas de processos comunicativos e um repertório comum, pois ainda recorrem ao ambiente para reproduzir parte de seus elementos funcionais e códigos de funcionamento. Esses "sistemas" operam, então, a partir da alopoiése, ou seja, buscam no ambiente elementos operativos internos. ${ }^{63}$ "Os limites entre sistema e ambiente não apenas ficam fracos, mas desaparecem.",64

Nesse caso, o sistema funciona com operações recursivas ao ambiente, descaracterizando assim a fronteira que o identifica. O sistema, dessa maneira, definido por critérios externos, deixa de dar sentido a algumas de suas próprias operações e não executa totalmente sua capacidade de abertura cognitiva, responsável pelo desenvolvimento e evolução internos do sistema.

Com a alopoiése, não podemos falar em um sistema social consolidado, pois fica prejudicado o entendimento desses sistemas como autônomos, fechados operacionalmente e auto-referentes, além de eventualmente titulares de um meio de comunicação simbolicamente generalizado. Nestes sistemas, tanto a auto-referência basal como a reflexividade, ou autoreferência processual, e a reflexão são prejudicadas e o limite entre sistema e ambiente fica obscurecido. Sistemas alopoiéticos não são capazes de reinterpretar as determinações ambientais de acordo com seus próprios códigos internos de operação.

Tais sistemas não podem ser considerados autônomos a menos que, em um processo de evolução e diferenciação em relação ao ambiente - que não é necessário, nem provável, nem definitivo, mas possível -, passem a barrar a influência externa e a operar com seus próprios elementos, por meio da definição de uma fronteira, uma forma, e recorrendo apenas ao seu próprio repertório para dar conta dos processos comunicativos internos, completando, assim, seu processo de diferenciação funcional.

\footnotetext{
${ }^{63}$ Cf. Neves M. "From the Autopoiesis to the Allopoiesis of Law". In: Journal of Law and Society. Vol. 28, n. 2, 2001, p. 255.

${ }^{64}$ Neves, "From the Autopoiesis to the Allopoiesis of Law", op. cit., p. 260
} 
O que vai ser tratado neste capítulo não se refere, no entanto, aos sistemas alopoiéticos, ou seja, com fechamento operacional incompleto. Ao invés de analisar os casos de não formação do sistema social autopoiético, vamos nos concentrar na análise da relação de sistemas autopoiéticos consolidados com seu ambiente e nas possibilidades, dentro da teoria dos sistemas sociais, de que o ambiente, ou outros sistemas do ambiente, possam direcionar alguns processos comunicativos internos dos sistemas sociais autopoiéticos por meio de injeção de complexidades estruturadas na forma de informação.

Procuraremos explicar a hipótese de que influências externas podem ocorrer mesmo em sistemas sociais consolidados - capazes de reinterpretar as ocorrências ambientais sob suas próprias operações - no momento em que estão em funcionamento o acoplamento estrutural, as interpenetrações e as interações. A possibilidade de ocorrência de influência externa nos sistemas sociais, quando há acoplamento estrutural, é particularmente maior quando o acoplamento entre dois sistemas sociais ocorre simultaneamente à existência de interpenetrações e interações, que podem possibilitar as influências externas dirigidas e programadas. 


\section{IV.2 Processos sobrecomunicativos}

Sistemas sociais complexos, consolidados e autopoiéticos podem sofrer influências externas em determinadas situações. Esta hipótese, apesar de não aparecer exposta claramente no desenho da teoria dos sistemas sociais, encontra respaldo em passagens do próprio Luhmann: "Formas de acoplamento estrutural, portanto, restringem e facilitam, por meio disso, influências do ambiente sobre o sistema"65 e "organizações são os únicos sistemas sociais que podem se comunicar com os sistemas de seu ambiente" ${ }^{\text {66 }}$, por exemplo.

Também no trabalho de autores que desenvolvem seus escritos a partir do aparato conceitual teórico-sistêmico, como Gunther Teubner ${ }^{67}$, Wolfgang Krohn ${ }^{68}$ e Günter Kuppers $^{69}$, encontram-se desenvolvimentos similares. Pode-se verificar que mesmo em autores que não trabalham explicitamente com esta perspectiva, como Marcelo Neves, existe o reconhecimento da possibilidade de existirem "obstruções eventuais à reprodução autopoiética de um sistema" ${ }^{, 70}$.

\footnotetext{
${ }^{65}$ Luhmann, N. Das Recht der Gesellschaft. Frankfurt a.M., Suhrkamp, 1995, p. 441 (grifos nossos).
}

${ }^{66}$ Luhmann, Die Gesellschaft der Gesellschaft, op. cit. p. 842 (grifos nossos).

${ }^{67} \mathrm{O}$ jurista alemão pode ser considerado um discípulo heterodoxo de Luhmann, já que desenvolve grande parte do seu trabalho em Sociologia do Direito com o instrumental luhmanniano, mas tenta elaborar, a partir da matriz, linhas de raciocínio originais. A exposição completa de um programa de influência externa elaborado por Teubner está em Direito, sistema e policontexturalidade (Piracicaba, Unimep, 2005, pp. 38 e ss). O autor, no entanto, também destaca em $O$ direito como sistema autopoiético (Lisboa, Editora Universitária, 1989, pp. 74 e 75), o processo de substituição na teoria dos sistemas de modelos simples de causa-efeito pela noção de perturbações, que não exclui a idéia de influências externas: "Em face da característica circularidade da organização interna do sistema jurídico, os modelos de causalidade explicativos das influências externas respectivas tornam-se necessariamente mais complexos, devendo por isso substituir-se a simples lógica causaefeito por uma lógica de perturbação. Os fatores capazes de influenciar do exterior o direito devem ser descritos à luz do modelo das máquinas não triviais de Von Foerster, tal como foram anteriormente analisadas. Nesta acepção, a autonomia jurídica não exclui, mas antes pressupõe, a possibilidade de interdependência entre sistema jurídico, sistema político e sistema econômico, com a ressalva de estar aqui perspectivada e entendida como um problema de influência externa sobre processos causais circulares internos".

${ }^{68}$ Professor de Sociologia da Universidade de Bielefeld, do mesmo departamento de Luhmann. Publicou com Kuppers o artigo "Selbstreferenz und Plannung" (Auto-referência e planejamento), no periódico Selbstorganszation, n. 1, 1990, pp. 101-127, onde apresentam a idéia de perturbações externamente orientadas a produzir efeitos internos ao sistema.

${ }^{69}$ Professor de Física da Universidade de Bielefeld, especializado em Teoria dos Sistemas. Trabalhou com Luhmann nos últimos anos da carreira do sociólogo.

${ }^{70}$ Neves, "From the Autopoiesis to the Allopoiesis of Law', op. cit., p. 259, (grifos nossos). Depois de expor o conceito de alopoiése de sistemas jurídicos em países periféricos, Neves esclarece que a alopoiése não trata de obstruções eventuais à autopoiése, mas de inexistência de autopoiése : "Dessa maneira, não estamos lidando com obstruções eventuais na reprodução autopoiética do direito positivo, que deveriam ser superadas por meio de mecanismos de imunização complementar do mesmo sistema jurídico em questão". Isso indica o reconhecimento por parte do autor da possibilidade da existência de tais obstruções eventuais, que não extinguiriam a autopoiése dos sistemas. Em nossa hipótese, estas obstruções eventuais são apresentadas como processos sobrecomunicativos. 
A mais importante contribuição neste sentido, no entanto, foi a do sociólogo alemão Helmut Willke, que trabalhou com Luhmann na Universidade de Bielefeld e desenvolveu a teoria da regulação social (Theorie gesellschaftlicher Steuerung) ${ }^{71}$, da qual o conceito mais importante é o da regulação contextual, de onde os autores supracitados, chamados de pósluhmannianos, partiram para o desenvolvimento de seus trabalhos nesta linha.

Por meio deste conceito, Willke apresenta um esboço de sistematização das formas de organização dos sistemas sociais. Segundo ele, a evolução, o primeiro formato, é caracterizada pelo desenvolvimento livre e, muitas vezes, caótico do sistema - não há, neste caso, nenhum tipo de intervenção, ainda que haja a conservação da unidade do sistema apesar das alterações estruturais; o planejamento, o segundo formato, seria o oposto, com a imposição de regras de um sistema sobre outro, em vias de desaparecer no contexto dos sistemas sociais funcionais; e, o terceiro, a orientação contextual, que seria um nível médio de intervenção e consiste em manobras orientadas de um sistema objetivando direcionar a evolução de outro sistema. O sistema interveniente maneja as contingências apoiando ou impedindo certas seleções do sistema que sofre a intervenção, de modo a direcionar as escolhas deste último, criando um marco de mudança. ${ }^{72}$

Apesar da similaridade com o presente trabalho - no tocante ao estudo da interferência externa nos sistemas sociais -, os conceitos que serão apresentados aqui são diferente dos apresentados por Willke - mas de certa maneira complementares -, à medida que este trabalho busca diferenciar as formas pelas quais as interferências externas ocorrem nos sistemas sociais e aquele procurou diferenciar as formas pelas quais os sistemas sociais levam a cabo seu desenvolvimento, sendo uma delas a orientação contextual, que cobre apenas uma parte das interferências externas, já que, em nossa hipótese, o processo de evolução também apresenta elementos de interferência externa, neste caso não orientados sistematicamente.

O principal mecanismo pelo qual a influência de um sistema social autopoiético sobre outro pode ser canalizada é o acoplamento estrutural. É importante frisar que, na hipótese

\footnotetext{
${ }^{71}$ Luhmann refere-se ao trabalho de Willke na versão final de Die Gesellschaft der Gesellschaft, op. cit., p. 843, mas nada havia mencionado na versão preliminar da obra, publicada em co-autoria com Rafaelle De Georgi sob o nome de Teoría de la Sociedad, op. cit.

${ }^{72}$ Cf. Willke, H. "Societal guidance through law?". In: Teubner, G. \& Febrajjo, A. (eds.) State, law and economy as autopoietic system: regulation and autonomy in a new perspective. European Yearbook in the Sociology of Law. Milão, Giuffre, 1992, pp. 353-387.
} 
proposta neste trabalho, não há a eliminação da autopoiése e os sistemas continuam sendo autônomos e fechados operacionalmente.

No caso de influências externas sobre sistemas autopoiéticos, diferentemente dos casos de sistemas com fechamento operacional incompleto, ou alopoiéticos, existe a possibilidade de suspendê-las a qualquer momento. Para isso ocorrer, no caso dos sistemas consolidados, basta ao sistema que está sendo influenciado colocar em funcionamento as operações internas já existentes de diferenciação do ambiente. Esta suspensão, no entanto, pode demorar a ocorrer e não é realizada automaticamente, pois as influências ocorrem em pontos cegos no campo de auto-observação dos sistemas e na intersecção de funcionamento do acoplamento estrutural ocorridas no âmbito do sistema.

A influência externa caracteriza-se pela ocorrência de formação do sentido e realização de processos comunicativos completos ou de parcelas constitutivas do processo no interior de um sistema social a partir de processos comunicativos de outro sistema social, com a manutenção da oposição binária original do sistema que influencia nas operações de outro, ainda que de forma subliminar.

A maneira mais aparente desta interferência externa é a utilização da semântica de um sistema social para designar aspectos de outro - ter/não ter traduzido em poder/não poder, mas, no caso aqui apresentado, essa influência ocorre de modo menos aparente, ou seja, quando uma parcela do processo comunicativo (informação, participação e compreensão) é formulada em um sistema e completa o processo comunicativo em outro, ou então quando, entre um processo comunicativo e outro subseqüente no mesmo sistema, ocorra um processo comunicativo necessário em outro sistema, que direciona a formação de sentido naquele primeiro. Esta ingerência é facilitada quando os processos comunicativos ocorrem a partir de programas de sistemas diferentes que, pelo menos em tese, encaminham-se para demandas convergentes, por exemplo: a ampliação da área comum de abrangência ${ }^{73}$, a contraposição conjunta de dois sistemas acoplados a situações sociais externas ${ }^{74}$ ou a aliança de subsistemas

\footnotetext{
${ }^{73}$ Quando, por exemplo, os programas dos sistemas econômico e político de determinada sociedade convergem para a formatação de um plano de investimentos, como a discussão das leis das Parcerias Público-Privadas (PPPs) no Brasil.

${ }^{74}$ Um exemplo desta situação foi a discussão sobre a autorização legal do aborto de fetos anencefálicos, quando a Igreja utilizou argumentos convergentes com o entendimento do sistema direito acerca de vida e doação de órgãos para evitar a autorização defendida pelo sistema ciência.
} 
contra pressões de terceiros sistemas para a desintegração daqueles, por exemplo, em situações de guerra.

A toda esta influência externa vamos chamar de processos sobrecomunicativos, que podem ocorrer de duas formas.

A primeira diz respeito ao processo de observação constante de um sistema pelo outro, quando o sistema que observa detecta a forma pela qual a rede recursiva de premissas direciona freqüentemente as decisões no sistema observado e começa a produzir informações direcionadas especificamente para serem aproveitadas pelos processos comunicativos do sistema observado, estimulando a seleção dessas informações como válidas com a caracterização de parte da informação em formatos reconhecidamente utilizados pelo sistema observado como válidos em um longo histórico de seleções passadas.

Assim, o sistema que observa produz objetivamente ruídos com as características favoráveis, segundo o histórico de observação, para que sejam validados como informação pelo sistema que é observado. A exposição a irritações repetidas e constantes direciona o desenvolvimento do sistema observado sob as condições impostas pelo sistema que observa, pois podem ser gerados focos de irritação freqüentes e muito específicos.

Pela teoria dos sistemas sociais, o ambiente consegue exercer um influxo sobre o desenvolvimento estrutural dos sistemas somente sob condições em que se produzam acoplamentos estruturais e somente na fronteira das possibilidades de auto-irritação canalizadas e acumuladas pelo acoplamento estrutural. O resultado deste desenvolvimento é sempre contingente e não há como garantir os resultados de um plano previamente estruturado; porém isto não exclui a possibilidade de o plano atingir seus objetivos. Como no exemplo do jogo de xadrez, os movimentos posteriores do jogador oponente podem ter sido acertados pelo jogador que planejou uma estratégia, com algumas jogadas, depois de observar muitas vezes seu oponente jogar e detectar a resposta mais freqüente, ainda que não necessária, a determinados estímulos.

Nesse formato, que vamos chamar de processos sobrecomunicativos resultados de observação continuada, as informações são irritações, mas o êxito dessas informações em serem seguidamente tomadas como válidas coloca o sistema observado sob influência do sistema que observa sem o conhecimento ou consentimento daquele. 
A outra forma de influência externa em sistemas sociais consolidados consiste em falhas no processo de diferenciação no momento do funcionamento de operações simultâneas de interpenetração e interação ocorridas no âmbito das relações entre sistemas sociais, ou seja, na intersecção de processos comunicativos de sistemas acoplados. Nesse caso, os processos comunicativos se completam, mas ao final deles, o sentido obtido pelo sistema sofre um desvio, pois foi composto simultaneamente de parcelas de processos comunicativos dos outros sistemas envolvidos no acoplamento.

Além do desvio poder ocorrer em processos comunicativos simultâneos, há também a possibilidade de esse desvio ocorrer no caso de processos comunicativos com um pequeno intervalo temporal, por exemplo, em situações em que o conjunto dos processos comunicativos seja composto de uma parcela interacional - portanto presencial - e de uma parcela mediada, seja por mensagens eletrônicas, correspondências, relatórios, etc., pois o processo comunicativo de um sistema acoplado é iniciado antes de o processo comunicativo de outro sistema se ter completado. Nesse caso, a evolução, que ocorre na passagem de uma operação à outra, pode ser gerada com informações ou participações de processos comunicativos diferentes. A hipótese é a de que esses desvios sejam uma das explicações de porque a evolução dos sistemas pode gerar estruturas diferentes a partir de condições aparentemente idênticas ${ }^{75}$.

A esses dois tipos de eventos denominaremos processos sobrecomunicativos resultados de desvios de acoplamento.

Vale ressaltar que os processos sobrecomunicativos podem ser observados enquanto os sistemas mantêm sua capacidade de reelaborar as informações do ambiente - ainda que

\footnotetext{
75 A questão das evoluções diametralmente díspares de conjuntos similares - mas não totalmente idênticas - de características iniciais de dois processos comunicativos, que tanto atormenta planejadores e gestores, tem desenvolvimentos bastante interessantes em outros discursos teóricos, como o das áreas da matemática e da física, com a teoria do caos determinístico e dos fractais, com explicações sobre a possibilidade de evoluções extremamente diferenciadas. Na sociologia, no entanto, o campo mais fértil que se apresenta para o desenvolvimento, e principalmente aceitação, deste diagnóstico é a Teoria dos Sistemas Sociais, já que nesta a contingência é tomada como elemento central da teoria e evoluções em direções opostas são tomadas como probabilidade dominante e não como anomalia. Em outros contextos, tais como a expressão artística, tanto na literatura quanto no cinema e nas artes plásticas, esses recursos já estão sendo utilizados. Para mais detalhes sobre teoria dos fractais e do caos: Mandelbrot, B. Objetos Fractais. Lisboa, Gradiva, 1992; Barbosa, R. M. Descobrindo a geometria fractal. Belo Horizonte, Autêntica, 2002; Merry, U. Coping with Uncertainty Insights from the New Sciences of Chaos, Self-Organization, and Complexity. Westport, Praeger, 1995.
} 
estejam sob influência externa eventual. Não podemos descartar, no entanto, as possibilidades de processos sobrecomunicativos acarretarem o desaparecimento de um dos sistemas acoplados, com o desaparecimento da autopoiése de maneira irreversível e com a destruição dos limites entre os sistemas acoplados, ou ainda a criação de um novo sistema social original, com um novo código de comunicação, diferente dos dois códigos primários dos sistemas acoplados.

Para a verificação destas hipóteses, seria válido o trabalho de reconstrução do histórico de alguns sistemas sociais, principalmente os de tipo organização, como o Estado e a universidade, entre outros, para traçar os possíveis acoplamentos primordiais entre sistemas anteriores a estas organizações, como os sistemas Religião, Política e Direito, e verificar a presença de processos sobrecomunicativos na gênese de tais organizações. Pesquisas nesse sentindo foram iniciadas por Luhmann, com os estudos de estrutura social e semântica (Gesellschaftstruktur und Semantik), mas ele não conseguiu completá-las. 


\section{IV.3 Suspensão dos processo sobrecomunicativos}

Os sistemas sociais autopoiéticos consolidados podem suspender as influências externas por meio de suas próprias operações e estruturas. Para reestabelecer plenamente sua autonomia, os sistemas sociais podem tanto realizar uma operação de auto-observação recursiva, perceber os desvios e oferecer respostas diametralmente contrárias às esperadas pelo ambiente, ou sistema do ambiente, que exerce a influência, como também oferecer respostas diferentes das que oferece comumente, pondo em operação a variabilidade que sua autopoiése permite. Assim, os processos sobrecomunicativos não pressupõem uma subordinação de um sistema em relação ao seu ambiente ou a um sistema do ambiente, nem o fim do fechamento operacional, mas desvios e influências planejadas ou não do exterior em relação ao sistema operante, que não enxerga o funcionamento destas influências, pois formalmente continua realizando seus processos comunicativos, operando suas estruturas e seu meio de comunicação simbolicamente generalizado.

Em alguns casos, se o sistema perder a capacidade de realizar as diferenciações em relação ao ambiente, tornando-se refém do complexo de estímulos externos de modo irreversível, ele pode perecer antes mesmo de reestabelecer sua autopoiése. Isto está em consonância com a teoria dos sistemas sociais, pois a autopoiése do sistema representa sua reprodução e sua sobrevivência. Além disso, na teoria dos sistemas sociais, os sistemas são efêmeros e dinâmicos e, mesmo os mais consolidados, estão sujeitos a desaparecer, à medida que seu código de comunicação perder a capacidade de organizar sentido e, portanto, de realizar a diferenciação funcional e estabelecer os limites com o ambiente.

Mas por que o sistema é atingido por tais influências externas, se observa a si mesmo a fim de garantir sua sobrevivência? A explicação pode estar no funcionamento dos programas, da racionalidade do sistema e dos acoplamentos estruturais.

O sistema não pode estender a racionalidade e a auto-observação ao exato momento em que leva a cabo um processo comunicativo. A auto-observação pode ocorrer apenas em um momento posterior ou sobre elementos que fazem parte do processo que ocorre, mas que não estão em funcionamento naquele momento. Essa impossibilidade de o sistema operar e observar simultaneamente sua operação de observação e, portanto, de avaliar a eficácia da 
diferenciação de seu processo comunicativo ocorre porque nenhuma observação pode observar a si mesma. ${ }^{76}$

Assim, no instante em que o sistema está processando a comunicação, ele não pode verificar se esse processamento está diferenciado do ambiente, o que pode realizar num momento imediatamente posterior ou por meio do funcionamento dos programas, que por sua vez, também podem inserir critérios estranhos ao sistema no momento das operações propriamente ditas. ${ }^{77}$ Essa impossibilidade de controle total dos processos de diferenciação dos sistemas sociais, causada pela impossibilidade da racionalidade plena, gera para o sistema essas aberturas para influências externas. "A racionalidade não aparece apenas como paradoxo, mas como impossível ao sistema."

Por sua vez, o acoplamento estrutural é o momento em que esse processo de influência externa é possibilitado, já que são travadas relações no limite do sistema com o ambiente, possibilitando ao sistema utilizar estruturas de outros sistemas, mas também colocando as suas próprias estruturas à disposição dos outros sistemas. No acoplamento estrutural são canalizadas irritações do ambiente, originando um fluxo estrutural, e o processo comunicativo adquire sentido nos dois ou mais sistemas acoplados. Isto gera processos comunicativos subsequientes em tais sistemas e o aumento da possibilidade de ocorrência de processos sobrecomunicativos resultados de desvios de acoplamento e também de observação continuada.

Assim, o acoplamento estrutural, à medida que significa a simultaneidade de processos comunicativos em sistemas diferentes com a utilização de elementos comuns, pode ocasionar a influência externa no sistema.

Vale lembrar que em todos os momentos o sistema utiliza elementos externos para a produção de processos comunicativos internos, à medida que filtra os elementos do ambiente e toma alguns ruídos como informação para seu processo comunicativo. Este processo, no entanto, normalmente é realizado a partir das premissas internas do sistema.

Suspender os processos sobrecomunicativos que influenciam seus processos comunicativos internos consiste, então, apenas em retomar as premissas internas, recuperar as operações recursivas, reafirmando o código interno que, neste caso, ainda não terá sido

\footnotetext{
${ }^{76}$ Cf. Baraldi, Corsi \& Espósito, Glossar, op. cit., p. 125.

${ }^{77}$ Cf. Baraldi, Corsi \& Espósito, Glossar, op. cit., p. 140.

${ }^{78}$ Luhmann \& De Georgi, Teoría de la sociedad, op. cit., p. 79.
} 
perdido ou irrecuperavelmente destituído da capacidade de constituir sentido pelo seu processo de diferenciação binário. Caso isto não seja mais possível, não se trata mais de processos sobrecomunicativos, mas de corrupção destrutiva, alopoiése, do desaparecimento de sistema como autopoieticamente autônomo.

A diferenciação de um processo sobrecomunicativo e de um processo de destruição total da autopoiése do sistema necessita de uma observação acurada e pode ser realizada a partir da avaliação da manutenção da capacidade de elaborar sentido do código binário exclusivo do sistema. De uma perspectiva empírica, esta avaliação envolveria o trabalho de pesquisa sobre as operações de determinado sistema, seu histórico de diferenciação, a conformação de seu código binário, a validade de aplicações posteriores do código e a capacidade de barrar a influência externa.

A premissa é a de que os sistemas sociais descritos nos trabalhos de Luhmann direito, arte, política, ciência, economia, religião, entre outros - continuam a se constituir em sistemas autopoiéticos mesmo no Brasil, onde podemos colher diversos exemplos de processos sobrecomunicativos. Primeiro porque os processos evolutivos destes sistemas continuam a ocorrer; em segundo lugar, porque as operações próprias destes sistemas já atingiram um grau de autonomia capaz de barrar influências e pressões externas recorrendo exclusivamente a normativas internas; e, em terceiro lugar, todos apresentam seus códigos binários muito bem definidos e eficazes. 


\section{IV . 4 Processos sobrecomunicativos resultados de observação continuada}

A relação duradoura entre sistemas sociais distintos, como vimos, gera a formação de acoplamentos estruturais, na forma de institutos que não formam sistemas, como o orçamento público, ou na forma de mecanismos inter-sistêmicos, que podem formar sistemas do tipo organização, como o Estado ${ }^{79}$ e as escolas.

Nestas estruturas, os processos comunicativos produzem sentido em ambos os sistemas acoplados. Assim, em acoplamentos estruturais que funcionam como organizações, os sistemas acoplados produzem seus processos comunicativos com premissas que fazem parte de ambas as redes recursivas, muitas vezes com significados diferentes, mas expressos nos mesmos elementos; por exemplo: as emendas orçamentárias votadas pelo Congresso Nacional têm significado para os sistemas política e economia, assim como a votação de uma emenda ao código civil ou penal, tem significado tanto para o sistema política quanto para o sistema direito.

Como as relações formadas com o auxílio do mecanismo de acoplamento estrutural, que se organizam em sistemas organizacionais, são relações consolidadas, as premissas de ambos os sistemas que se tornam recorrentes podem ser observadas pelo sistema acoplado durante um período longo. A perspectiva é que essa observação possa produzir um reconhecimento das respostas mais comuns, ou pelo menos de grande parte das respostas possíveis, aos processos comunicativos de um sistema pelo outro sistema acoplado. O extenso relacionamento permite, além disso, produzir uma avaliação das possibilidades de resposta do sistema por um longo período. Como no exemplo do jogo de xadrez, onde um bom jogador tem a capacidade de elaborar um esquema de jogadas e contra-jogadas, conhecendo bem as regras e as estratégias vencedoras. Desta forma, não apenas o sistema aprende quais operações possibilitam afirmar-se diante do ambiente e tornar-se diferenciado, como também aprende quais operações geram irritações que podem adequar-se ao padrão de diferenciação do sistema acoplado.

Novamente utilizando a analogia do jogo de xadrez, isso não impede que as respostas do sistema a determinados processos comunicativos surpreenda a previsão inicial, tornando o

\footnotetext{
${ }^{79}$ Cf. Luhmann, Die Politik der Gesellschaft, op. cit., p. 390.
} 
esquema pré-concebido totalmente inválido e inútil. As possibilidades de as previsões se concretizarem, no entanto, não são desprezíveis.

Um programa consciente de construção de um fluxo de influências de um sistema neste caso o direito - sobre outro foi descrito por Teubner no artigo "Direito Regulatório Crônica de uma morte anunciada", utilizando as conclusões de autores que pensam o planejamento estatal a partir do arcabouço da teoria dos sistemas sociais:

"Quando sistemas recursivos e auto-organizados podem realizar valores próprios, em razão de perturbações externas, então o direito pode tentar, por produção normativa geral ou por atos jurídicos especiais, produzir perturbações de forma orientada e, apesar de todo o caos individual, irritar os sistemas recursivos de maneira que eles consigam mudar de um estado atrator a outro, com o qual o objetivo legal seja, pelo menos, compatível. Sem dúvida, tal shake-up de uma instituição, apoiado em um processo de auto-organização atrativo dentro dela mesmo representa uma estratégia de alto risco, pois nada garante o 'caminhar' na direção de um atrator desejado. Em princípio, três alternativas revelam-se sempre possíveis de acontecer: desintegração a uma instituição 'quebrada', direcionamento a um atrator que não corresponde às intenções desejadas e, por fim, com um pouco de sorte, tudo ocorre bem, o direcionamento a um atrator compatível com o objetivo da lei." ${ }^{, 80}$

Neste caso, o processo sobrecomunicativo foi deliberadamente elaborado para direcionar, através de irritações orientadas - leis e outros atos jurídicos -, outros sistemas à escolha do legislador. Nesta abordagem há a perspectiva normativa, que pode fazer supor que esta influência externa só seria possível na relação inter-sistêmica com diferenças de hierarquia ou com a utilização de vetores de poder - como uma "hiper-jurisdicionalização" da vida social. A hipótese deste trabalho, entretanto, não envolve vetores de poder como fator determinante, inclusive porque este vetor é o código de apenas dois sistemas sociais: a política e o direito. Trabalha-se, no entanto, com a possibilidade de o aprendizado em relação a outros sistemas ocorrer em qualquer sistema organizado e acoplado a outros.

80 Teubner, Direito, sistema e policontexturalidade, op. cit., p. 38. O autor chama de atratores os direcionamentos possíveis - desejados ou não - da evolução sistêmica. O termo é emprestado da física, onde significa o ponto (ou área) para o qual se direciona um sistema complexo. Segundo o autor, estes atratores, no caso dos sistemas sociais, apesar da contingência geral, podem ser identificados em um longo processo de pesquisa empírica para a determinação de pontos de intervenção sensitivos, de acordo com o histórico do sistema, que pode apresentar períodos de estabilização. Isso nada mais é do que aquilo que chamamos aqui de observação continuada. Em ambos os casos, o sistema que deseja produzir irritações direcionadas precisa 
Para ilustrar a formação dos processos sobrecomunicativos resultados de observação continuada, é útil examinar uma recorrente no processo eleitoral no Brasil: o financiamento das campanhas eleitorais. Destacaremos, desse modo, algumas observações acerca das eleições realizadas no município de São Paulo em 2004, para o cargo executivo de prefeito e para os cargos legislativos de vereador. ${ }^{81}$ Neste caso, o sistema economia, depois de observar e "aprender" como ocorrem os processos comunicativos do sistema política, passa a influenciar operações deste sistema.

Algumas formas de financiamento das campanhas eleitorais podem se constituir claramente em uma forma de ingerência do sistema economia sobre o sistema política, já que a diferença de recursos pode se traduzir em campanhas mais opulentas e mais abrangentes, ampliando diferenças de informação naturalmente existentes entre os eleitores, propagando idéias com mais eficácia e tornando o debate político das eleições em um monólogo. Obviamente, já presenciamos campanhas muito caras se mostrarem ineficazes, principalmente as campanhas para os cargos executivos, cujo apelo personalista e carismático é muito forte e pode reverter quadros de diferença de orçamento das campanhas. Nas eleições legislativas, no entanto, o peso do orçamento da campanha é muito mais forte e a eficácia dos processos sobrecomunicativos é historicamente maior.

Exatamente para controlar a influência do sistema economia sobre o sistema política, a legislação eleitoral do Brasil criou mecanismos para limitar a utilização de recursos nas campanhas eleitorais. A lei federal $n^{\circ}$ 9.504/97 limitou as doações em dinheiro para as campanhas eleitorais a, no máximo, $2 \%$ do faturamento bruto da empresa doadora no ano anterior ou, no caso de doação de pessoa física, a $10 \%$ dos rendimentos brutos no ano anterior, sob pena de o candidato responder judicialmente por abuso de poder econômico, além de o partido político ser suspenso do repasse de fundos partidários legais. A limitação para a utilização de recursos próprios pelos candidatos pode existir, mas fica a cargo de cada

conhecer os modos de operação do outro sistema para produzir ruídos com mais chances de serem reconhecidos como informação pelo sistema observado e "atrair" a evolução do sistema para o caminho, ou atrator, desejado.

${ }^{81}$ O número de eleitores no município de São Paulo naquela eleição foi de 7,7 milhões, número maior do que a população total de países como Suíça, Noruega, Finlândia e Dinamarca, e maior do que o número de eleitores de países como Suécia, Bélgica, Portugal, e Áustria. Além do cargo de prefeito, estavam sendo renovadas 55 vagas de vereador. O número de votos para a eleição de um vereador em São Paulo, em tese, é de 140 mil, número maior do que a população de cerca de $90 \%$ das cidades do Brasil. As abstenções, os votos nulos e em branco e os votos nas chapas, os chamados votos de legenda, fazem este número cair para cerca de 20 mil votos nominais, quantidade que elegeria cerca de $60 \%$ dos prefeitos do país. 
um dos partidos, que tem registrar este limite no mesmo momento do registro da candidatura, segundo a resolução 21.609, de 2004, do Tribunal Superior Eleitoral.

Além disso, a lei 9.504/97 também restringe a doação para as campanhas eleitorais de recursos provenientes de concessionárias de serviços públicos, entidade de utilidade pública e órgão ou fundação mantida com recursos públicos. Essas restrições visam a, claramente, garantir maior independência entre os sistemas, de um lado limitando a utilização de todos os recursos da superioridade econômica de um candidato e de seus correligionários e, de outro, limitando a utilização de vantagens indiretas e ligações com o poder público (concessionárias e entidades de utilidade pública) e proibindo a contrapartida direta aos candidatos dos partidos da situação responsáveis pela aprovação de contratos de prestação de serviços ao poder público, de concessionárias de serviços públicos, de financiamento de projetos e de contratação de pessoal. Vale ressaltar que as operações econômicas das concessionárias não são serviços beneficentes, mas respondem à lógica econômica tradicional - geração de lucro gerando inclusive disputas entre as empresas em leilões e licitações pelo controle de tais contratos.

O direito brasileiro trata do tema de contrapartidas a vantagens auferidas no sistema político também no código penal, no artigo 332, dessa vez não apenas no que diz respeito ao processo eleitoral, mas em relação a todos os atos administrativos. Trata-se do crime de tráfico de influência. Apesar de podermos fazer várias objeções ao funcionamento fático da fiscalização ou das formas de averiguação de denúncias, investigação e punição, não podemos desprezar a eficácia normativa dos mecanismos legais contra este crime, que já levaram a processos de impedimento do próprio presidente eleito. Como o lobby não está regulamentado no Brasil, a legislação do país é mais rígida com estas atividades do que a norte-americana, por exemplo. Pelas leis norte-americanas, o lobby é permitido, existindo apenas a obrigação de que todos os engajados nesta atividade tenham de se registrar no governo e relatar semestralmente seus gastos, incluindo os salários de lobistas próprios e os honorários de escritórios contratados, as entidades contatadas e os temas e leis que foram objetivo de sua atividade no período. $^{82}$

${ }^{82}$ Cf. Godinho, R. Os diplomatas do Capitólio - A política externa norte-americana e a influência dos grupos de pressão no Congresso dos Estados Unidos. Brasília, Instituto Rio Branco, dissertação de Mestrado em Diplomacia, 2005, p. 98. O autor vai além na análise do lobby naquele país: "Esta é a face mais conhecida da atividade dos grupos de pressão nos EUA, mas comumente ela é apenas a ponta mais visível de um grupo de pressão que tem muitas outras faces. A pergunta que se pode fazer neste ponto é o que o lobista teria a oferecer 
O exemplo do modo como a legislação e o sistema político norte-americanos tratam o tema serve para ilustrar também que a questão dos processos sobrecomunicativos não está restrita a países periféricos, mas também afeta sociedades modernas, com sistemas sociais consolidados há muito tempo - no caso do sistema política nos Estados Unidos, há pelo menos 200 anos.

Não se trata, portanto, de analisar o ato delituoso e criminoso, que já está tipificado nos códigos, mas de analisar o que ocorre no processo eleitoral que não pode ser tipificado como tráfico de influência, pois não foi caracterizado como ingerência de um sistema sobre outro, mas de práticas ambíguas no decorrer do processo eleitoral e do financiamento da campanha.

As eleições municipais são as eleições com maior número de vagas no Brasil: 51.800. Somados a cada um dos postos eletivos, em média, já levando em consideração as eleições em cidades grandes e pequenas, mais 20 postos de nomeação direta ou indireta - entre assessores, secretários, funcionários de gabinete, administradores regionais, assessores e secretários destes administradores, além de indicações de contratações de funcionários de baixa qualificação admitidos por empresas terceirizadas, cuja contratação não depende de aprovação em concursos públicos - teremos cerca de 1 milhão de postos de trabalho que podem trocar de ocupantes depois das eleições. Do ponto de vista do sistema economia, estes postos de trabalho não são desprezíveis.

Além disso, cada legislatura municipal gera em média algumas dezenas de contratos econômicos de prestação de serviços, construções e locações que também não são desprezíveis para o sistema economia. Outro ponto importante do significado das eleições

aos parlamentares em troca da influência no processo legislativo. Não há uma resposta simples para isto. Por lei, o lobby está impedido de fazer contribuições de campanha. Em 1995, a recém-empossada Câmara, de maioria republicana, baniu toda e qualquer oferta de presentes, viagens, ingressos para eventos e refeições aos parlamentares ou aos seus assessores. Esta medida foi um duro golpe que alterou o método de trabalho de muitos lobistas. A situação tornou-se incômoda nos dois lados do balcão, como os congressistas foram percebendo. Aos poucos, a liderança Republicana foi relaxando suas próprias regras em sucessivos ajustes, até que, hoje, as coisas estão praticamente de volta ao "business as usual". O episódio ilustra a importância das relações pessoais e da troca informal de favores no dia a dia desta atividade. Embora os mimos, cortesias e refeições sejam importantes para o estabelecimento de contatos e facilite a abertura de acesso que, segundo profissionais do ramo, é o elemento básico, seria ousado demais dizer que os parlamentares como regra vendem-se por este tipo de presente". O excerto sugere que não se trata de corrupção, mas de algo muito mais complexo, mesmo nos Estados Unidos. 
municipais para o sistema economia são os decretos e resoluções que regulam a atividade econômica municipal, principalmente no que se refere à tributação de serviços, regulação de algumas atividades econômicas e tributação da propriedade urbana - um dos elementos mais tradicionais do sistema economia.

Como se pode ver, dos resultados das eleições, advêm diferentes possibilidades de direcionamento de vários elementos do sistema economia. Nada mais, porém, do que um acoplamento estrutural entre o sistema política e o sistema economia.

Quando, no entanto, recuamos a um momento antes das eleições, vemos, dessa vez, que os processos comunicativos do sistema economia também geram ruído e, por conseguinte, informação para os processos comunicativos da política. Em primeiro lugar, do ponto de vista dos eleitores, que, estimulados pela própria política, constroem uma ligação de causalidade entre os aspectos econômicos da sociedade e aspectos políticos. "Sob condição da democracia, com as eleições políticas abertas, pressupõe-se que os resultados da eleição reflitam a situação econômica, ou, mais especificamente, reflitam as transformações na situação econômica de um país." 83

Além disso, a diferença no financiamento das campanhas de cada candidato para os cargos legislativos municipais é um elemento potencialmente mais importante do que a diferença de recursos dos candidatos nas eleições para os cargos majoritários, pois a exposição dos candidatos aos cargos legislativos é menor, tanto nos meios de comunicação quanto no horário eleitoral gratuito e porque os valores gastos nas eleições legislativas são muito mais baixos, fazendo com que cada quantia mais de dinheiro no caixa de campanha, represente, percentualmente, mais na contabilidade final. Devemos lembrar que dificilmente, mesmo na cidade de São Paulo, há pesquisas de intenção de voto para vereador, que muitas vezes são o momento em que os eleitores conhecem os candidatos, e não há debates na televisão com estes candidatos. A diferença de capacidade de financiamento, assim, ganha mais importância nas eleições para o legislativo. Pois os candidatos a vereador têm gastos extras para informar os eleitores de sua candidatura - placas e muros pintados não têm o objetivo de persuadir o eleitor, mas apenas de informar que aquela pessoa - que pode ser um conhecido, um vizinho, um ex-professor, um conterrâneo ou até mesmo um parente distante do eleitor - é um candidato.

\footnotetext{
${ }^{83}$ Luhmann, Die Politik der Gesellschaft, op. cit., p. 385.
} 
As limitações dos candidatos no sistema economia - as diferenças entre os candidatos a partir da oposição ter/não ter - constituem ruídos para o sistema política, que geram informação para os processos comunicativos da política, que por sua vez geram informações para o sistema economia novamente.

A legislação tenta evitar exatamente que os aspectos do sistema economia que geram informação para o sistema política antes do momento das eleições gerem decisões políticas compensatórias após as eleições.

Como processo comunicativo ambíguo entre os dois sistemas, no momento anterior às eleições, temos as doações em dinheiro para as campanhas até o limite estabelecido na lei. Por um lado, não constituem abuso de poder econômico e são a expressão da preferência política dos eleitores, que colocam seus recursos a serviço de seus ideais políticos; por outro, sendo elemento relevante também no sistema economia, geram ruído e informação para o processo comunicativo do sistema política e, em caso de seleção como informação para este sistema, constituirá premissa de decisões também neste sistema.

Dessa forma, o candidato vencedor das eleições percebe o financiamento de sua campanha tanto como um elemento do sistema política - como a exteriorização de um apoio político de alguns eleitores -, como também um elemento do sistema economia - já que possibilita os pagamentos das contratações e aquisições necessárias para a campanha. Não há a necessidade de acertos e exigências de benefícios para que o financiamento da campanha do candidato se torne premissa de processos comunicativos posteriores, tanto no sistema economia como no sistema política.

As premissas, como vimos, estabelecem uma certa estabilidade no sistema, servindo como referenciais para processos comunicativos futuros. Assim, o financiamento das campanhas estabelece premissas que podem balizar processos comunicativos futuros tanto no sistema economia quanto no sistema política.

Alter pode verificar o histórico dos processos comunicativos realizados no sistema política advindos, depois de determinados processos comunicativos, do sistema economia ocorridos no período pré-eleições. A partir daí pode identificar os processos comunicativos no sistema economia que têm maior chance de produzir ruído e informação que estimule determinados processos comunicativos no sistema política no período pós-eleição. Esses processos comunicativos, por sua vez, estimulam processos comunicativos de volta, no 
sistema economia. Assim, entre dois processos comunicativos na economia, ocorreu um, necessário, em outro sistema - o da política.

Além do financiamento das campanhas ser potencialmente mais decisivo nas eleições para cargos legislativos, os processos comunicativos do sistema política operados por Ego na posição de candidato eleito para um cargo legislativo experimentam menos exposição nos meios de comunicação de massa, gerando menos ruído para a formação da opinião pública, portanto menos propenso a gerar o acoplamento estrutural do sistema política com o sistema meios de comunicação em massa. Protegidos das observações de segunda ordem e do sistema de tripla contingência ${ }^{84}$, os processos comunicativos do setor legislativo municipal do sistema política podem estar mais propensos a aceitar as premissas produzidas no acoplamento estrutural do período pré-eleições, ou seja, com o sistema economia e realizar, no período póseleições, processos comunicativos objetivados pelo sistema economia.

Os processos comunicativos próprios da política, como o preenchimento de cargos de chefia e comando não eletivos pelos candidatos eleitos para cargos no executivo também podem ser levados em consideração por Alter para identificar os processos comunicativos no sistema economia que podem produzir ruído e informação que aumentem a expectativa de determinados processos comunicativos serem realizados no sistema política no período póseleições.

Nas eleições, a expectativa de Alter, como financiador, portanto operando no sistema economia, das campanhas dos candidatos aos cargos legislativos é totalmente diferente na observação dos candidatos do partido vencedor e dos outros. A vitória nas eleições gera premissas de processos comunicativos posteriores, quais sejam, as nomeações dos secretários, assessores, etc. A observação do histórico do sistema política gerou, portanto, decisões totalmente diferentes de financiadores das campanhas de candidatos a vereador do partido vencedor e dos partidos vencidos, como vemos no exemplo abaixo.

${ }^{84}$ Strydom, P. "Triple contingency. Theoretical problem of the public in communication societies". In: Philosophy and Social Criticism, n. 25, 1999, pp. 1-25. Pela conceito de tripla contingência, o relacionamento entre sistemas é observado por outro sistema. Esta observação não é previamente conhecida, nem necessária, nem provável, mas é esperada e possível. A tripla contingência evoca a idéia de sistemas de controle e monitoramento - como o poder público, o Ministério Público e a imprensa - responsável pela formação da opinião pública, que, por sua vez, por um processo de re-entry, exerce papel importante no sistema política (a idéia de monitoramento - uma tripla contingência - também é utilizada como parte componente de algumas apresentações do sistema religião, na figura de um deus onipresente). 
O candidato que ficou em nono lugar entre os candidatos suplentes ${ }^{85}$ do partido vencedor das eleições para o cargo executivo conseguiu, trinta dias após a realização das eleições (prazo máximo para apresentação dos recibos de doações à Justiça Eleitoral), quitar as despesas de campanha com as doações recebidas. Apesar da ampla votação na legenda do partido vencedor da eleição do cargo executivo (que são computados no somatório com os votos nominais para a divisão das vagas legislativas em pleito), o candidato recebeu apenas cerca de 10 mil votos nominais. A percepção dos financiadores da campanha é a de que em alguns meses, por conta de nomeações e da distribuição dos cargos não eletivos, o candidato deva assumir uma vaga de vereador, para a qual é suplente, ou um cargo não eletivo na burocracia municipal.

A observação de Alter, como financiador da campanha, do histórico dos processos comunicativos do sistema política gera a expectativa de que, sem cometer ilícitos, as decisões de Ego, o candidato suplente, portanto operando processos comunicativos dos sistema política, como vereador empossado ou como comissário da burocracia municipal, possam trazer benefícios no sistema economia para Alter, direta ou indiretamente. Dentro do sistema economia, as doações tem relevância para um processo comunicativo e no sistema político para outro.

Ego leva em consideração o financiamento da campanha, como informação proveniente do sistema economia, no acoplamento estrutural, para processos comunicativos do sistema político.

Já o candidato que ficou em nono lugar entre os suplentes no segundo partido mais votado, mesmo obtendo cerca de 20 mil votos nominais, não havia conseguido recolher o dinheiro suficiente para pagar as contas da campanha dentro dos mesmos 30 dias. Depois do período regulamentar para apresentação dos recibos de doações, o candidato ainda realizava leilões de quadros e esculturas para pagar as dívidas do período eleitoral. A percepção do financiador - Alter operando no sistema economia - foi a de que, sem a perspectiva de o candidato assumir nenhum cargo na administração do partido opositor, o financiamento da campanha deste candidato não poderá formar premissas de decisão no sistema política.

Obviamente, estas considerações não sugerem que o candidato do partido vencedor das eleições vá incorrer em crime de tráfico de influência, mas, como vereador ou comissário

${ }^{85}$ Os candidatos derrotados são organizados em uma fila de suplência para eventual posse nos cargos, caso os 
da burocracia e como operador de processos comunicativos no sistema política, Ego terá à sua disposição processos comunicativos do sistema política que geram informações para o sistema economia: nomeações, contratos e indicações de nomeações e de contratos. Alter e Ego conhecem o histórico desse acoplamento estrutural e conhecem os processos comunicativos que estimulam em um e em outro sistema acoplado os processos comunicativos desejados.

Neste caso podemos apontar processos sobrecomunicativos resultado de observação continuada: processo de observação constante de um sistema pelo outro, onde o sistema que observa detecta a forma pela qual a rede recursiva de premissas direciona freqüentemente as decisões no sistema observado e começa a produzir informações direcionadas especificamente para serem aproveitados pelos processos comunicativos do sistema observado, estimulando a seleção dessas informações como válidas, mediante a caracterização de parte da informação em formatos sabidamente utilizados pelo sistema observado como válidos em um longo histórico de seleções passadas.

Não há, porém, determinações a priori, não há contratos prévios, pelo menos não válidos nem vinculantes no sistema política, não há acertos ou corrupção, ocorrências que poderiam ser apontadas como crime de tráfico de influência, mas a simples identificação de que certos processos comunicativos em um sistema acoplado aumentam a expectativa de alguns processos comunicativos em outro. Com a ressalva que as expectativas podem simplesmente não se realizar pelo fato de os sistemas serem autopoiéticos e de os processos comunicativos serem contigentes.

Assim, Alter pode financiar grande parte da campanha de Ego, e depois de uma vitória, os processos comunicativos realizados por Ego, como candidato eleito, não corresponderem às expectativas de Alter, sem prejuízo da manutenção do sentido das eleições dentro do sistema política, do sentido dos processos comunicativos levados a cabo por Ego dentro do sistema política e da auto-referência do sistema política frente ao sistema economia.

candidatos eleitos faleçam, sejam suspensos, impedidos ou licenciados para assumir outros cargos. 


\section{5 Processos sobrecomunicativos resultados de desvios de acoplamento}

Se a apresentação dos processos sobrecomunicativos por meio de observação continuada conta com algum aparato teórico já desenvolvido no campo da teoria dos sistemas sociais, a outra forma identificada de influência externa em sistemas sociais consolidados, por meio dos desvios de acoplamento, dispõe apenas de algumas pistas para sua conceitualização. Trabalharei com perspectivas já desenvolvidas dentro do arcabouço teórico-sistêmico, como os conceitos de acoplamento estrutural, de racionalidade e de programa, mas, na tentativa de esclarecer este conceito, utilizarei também algumas analogias com outros campos da ciência, principalmente a física e a neurologia - sempre tomando o cuidado de não oferecer simplesmente explicações neurológicas e psíquicas para os processos sobrecomunicativos resultados de desvios de acoplamento. O conceito foi elaborado a partir de um esforço de aplicar a teoria às observações dos sistemas sociais concretos, que muitas vezes apresentam tais desvios, mas há dificuldade em verificar estes desvios no registro teórico sistêmico, por dois motivos básicos.

O primeiro provém do próprio dinamismo do sistema. Seria necessário congelar cada momento para a verificação exata do momento do desvio de acoplamento, pois, diferentemente do caso da observação continuada, os desvios de acoplamento, na maioria dos casos, são efêmeros e seus efeitos são incorporados e relidos muito rapidamente, ou pelo menos em intervalos de tempo muito menores do que os dos processos sobrecomunicativos resultados de observação continuada. Em casos extremos, os desvios podem incorporar-se de tal modo às operações do sistema que passam a fazer parte das premissas e controlar sua autopoiése, mantendo sua diferenciação em relação ao ambiente, não mais com o funcionamento das operações antigas nem de operações do sistema originário da influência, mas sob uma terceira forma. "Por fim, os desvios controlam os mecanismos que são concebidos para controlar tais desvios. ${ }^{" 86}$ Este pode ser um caminho para a explicação da evolução dos sistemas de maneira imprevisível, efêmera e surpreendente.

\footnotetext{
${ }^{86}$ Becker, D. "Ranulph Granville und der Termostat: Zum Verständnis von Kybernetik und Konfusion”. In: Merkur, 1989, n. 43 (6) p. 514 apud Teubner, Direito, sistema e policontexturalidade, op. cit., p. 33. Mesmo sem estar apontando claramente o processo que descrevemos, Teubner utiliza a citação para exemplificar o processo de alteração, com elementos de outro sistema, do funcionamento do sistema direito. Ora, podemos encarar esta situação como simplesmente algo inexplicável, ou identificar nesta alteração pelo menos um padrão, o da influência externa que ocorre em intersecções de relações intersistêmicas, que é a minha hipótese.
} 
Outra dificuldade em detectar este tipo de influência externa ocorre quando não há um programa pré-definido para a operacionalização dos sistemas envolvidos. Como a ocorrência de processos sobrecomunicativos deste tipo pode não obedecer explicitamente às determinações operativas de um sistema de forma planejada, como no caso dos do tipo observação continuada (ainda que esta possibilidade exista), é provável que, neste caso, estes desvios sejam imperceptíveis sem o recurso da reconstrução do processo de evolução do sistema, isto é, eles não são reproduzíveis, ainda que possam ser planejados ou produzidos pelo sistema que deseja exercer a influência.

Se, por um lado, a inexistência de um programa dificulta o reconhecimento do processo sobrecomunicativo, por outro, é exatamente quando do funcionamento dos programas - meios pelos quais os sistemas observam e controlam as suas próprias operações -, que as ocorrências destas influências são mais numerosas. Neste caso, a dificuldade no reconhecimento destes processos sobrecomunicativos ocorre também porque elas são mais adaptadas ao funcionamento ordinário dos sistemas autopoiéticos, ou seja, na maioria das vezes, não são caracterizadas dentro da teoria dos sistemas sociais claramente como influências externas, com o argumento de que, ainda que estes elementos externos sejam inseridos nas formas de operação do sistema, o código definidor do sentido de determinado processo comunicativo seria o do sistema em questão e não do sistema do qual os elementos foram importados. Ao mesmo tempo em que os programas fixam o que deve ocorrer para que uma determinada operação possa acontecer, são eles que introduzem critérios estranhos ao funcionamento do sistema para a operacionalização de alguns resultados ${ }^{87}$. Defendemos que isto tem relevância não apenas como elemento interno dos sistemas sociais, mas também como processos sobrecomunicativos.

A dificuldade em observar esses processos sem a presença de um programa explícito orientando algumas ações, seja ele condicional (que estabelece uma seqüência de operações em um processo, determinando que operação deve seguir-se a determinadas circunstâncias) ou final (conseqüências que se espera que resultem das operações) ${ }^{88}$, é a de ser improvável a identificação dos vetores de intencionalidade dessas operações.

Independemente da maneira como estes processos possam ser observados - se por identificação do objetivo do programa do sistema que influencia ou pela reconstrução da

${ }^{87}$ Cf. Baraldi, Corsi \& Espósito, Glossar, op. cit., p.139. 
evolução dos sistemas envolvidos - o conceito de desvio de acoplamento está calcada em dois aspectos.

Obviamente, o primeiro trata da intersecção de diversas relações inter-sistêmicas: acoplamento estrutural, interpenetrações e intersecções - que tornam Alter destinatário de diversas comunicações simultâneas em acoplamentos estruturais de diferentes sistemas sociais. Como complemento deste aspecto, há o fato de que, na sociedade moderna, muitos conjuntos de processos comunicativos seqüenciais são constituídos de parcelas presenciais e não presenciais, o que apenas reforça a complexidade destas intersecções, pois envolvem as mediações, além de acoplamentos, interpenetrações e interações, o que pode potencializar as possibilidades de desvio. As mediações ampliam as possibilidades de interpretações da informação e tornam mais incertas as compreensões nos processos comunicativos - já que não há a possibilidade de esclarecimentos imediatos, comuns nas interações. Outro fator que pode potencializar a complexidade da intersecção das relações inter-sistêmicas é a presença da ironia $^{89}$, que gera informações com valores duplos e antagônicos, mesmo nos processos comunicativos presenciais.

O segundo ponto é a existência de resíduos de comunicação que ficam sem destinatário definido, mas que encontram continuidade em algum momento da existência de um ou outro sistema acoplado, aparecendo pelo "negativo", pelo rastro de sua existência. Os resíduos podem ser tanto (i) processos comunicativos completos, que geraram determinado sentido, mas cuja utilização como premissa para processos comunicativos ulteriores não ocorreu de maneira imediata, permanecendo em estado de suspensão, mas sem ser abandonado completamente, e (ii) informações que, também em estado de suspensão, são utilizadas no processo comunicativo em um momento posterior, tendo permanecido apenas como imagem na consciência ampliada de Alter. O termo consciência ampliada designa o conjunto de memória ${ }^{90}$, consciência de probabilidades futuras e auto-observação na

${ }^{88}$ Cf. Luhmann, Soziale Systeme, op. cit., p. 278

${ }^{89}$ A ironia é um potencializador da improbabilidade da efetividade da comunicação e introduz mais ruído nos processos comunicativos. Para alguns autores, no entanto, este ruído constitui-se em um fator essencial dos processos comunicativos e sua presença é uma fonte da evolução dos sistemas. Para mais detalhes ver: Rasch W. "Injecting Noise into the System". In: Niklas Luhmann's Modernity: The Paradoxe of Differentiation. Stanford, Stanford University, 2000. De certa forma, a idéia de que ruídos e resíduos possam ser responsáveis, pelo menos, por parte da evolução dos sistemas está contida no conceito de processos sobrecomunicativos.

${ }^{90}$ O termo memória é descrito por Luhmann como um mecanismo pelo qual o sistema explica sua atual situação e é utilizado para eximir os sistemas sociais do diagnóstico de que não podem controlar sua própria evolução (Cf. Luhmann, Die Gesellschaft der Gesellschaf, op. cit., p.578). Por esta descrição, a memória seria constituída 
neurologia. A consciência ampliada é formada pelos registros de experiências singulares ao longo da vida e pela capacidade de Alter de recuperar estes registros, assim como todo seu horizonte de referências, transformando-os em conhecimento e informação atual e em premissas para suas seleções futuras ${ }^{91}$. Assim como as premissas e processos comunicativos anteriores têm relevância para os sistemas sociais autopoiéticos, a consciência ampliada constitui material relevante para a tomada de decisões e seleções do sistema psíquico e, no nosso caso, ela importa para explicar o momento em que resíduos de outros processos comunicativos, ocorridos em outros contextos e sob o código de outros sistemas sociais, podem ser recuperados por Alter em determinados contextos de intersecção de interações, portanto na lida com Ego, sob os auspícios de outro código em outro sistema acoplado àquele. Neste caso, ocorre uma dissociação momentânea entre o que é informação do sistema psíquico e o que é informação disponível no sistema social no qual Alter está participando de um processo comunicativo.

Como analogia para o resíduo, podemos utilizar a figura dos neutrinos, que são partículas expelidas do núcleo do átomo quando um nêutron (carga nula de energia) se transforma em um próton (carga positiva), sendo emitidos do núcleo um elétron (carga negativa) e um neutrino, com massa minúscula e carga neutra. O somatório da carga final do próton criado e do elétron expelido, no entanto, não é igual ao da situação anterior - ou seja zero de carga do nêutron -, mas os neutrinos são tão minúsculos que não podem ser medidos. Os neutrinos podem ser observados e pesquisados apenas pelas impressões que deixam em alguns materiais, ou seja, a detecção ocorre de forma indireta, por "negativos" - rastros - que comprovam a passagem da partícula, mas que não apreende seu corpo. Além disso, os neutrinos atravessam os materiais de forma mais contundente que as outras partículas existentes no Universo e, por isso, podem atravessar distâncias de milhões de anos-luz quase intactos.

Da mesma forma que uma operação fundamental da composição do átomo (formação de seus prótons, elétrons e nêutrons) gera um resíduo pouco conhecido e invisível, sustentamos que os processos comunicativos geram resíduos dotados de sentido, que podem

apenas por eventos que fazem sentido para o sistema ou para a pessoa, por isso não estamos utilizando este termo para designar este repertório, de onde podem provir os resíduos comunicativos. Diferentemente desta acepção, estamos utilizando o termo consciência ampliada para designar um conjunto maior, em que também figuram elementos que não necessariamente já tenham sido dotados de sentido.

${ }^{91}$ Cf. Damásio, A. O mistério da consciência. São Paulo, Cia. das Letras, 2000, pp. 251-259. 
ser verificados apenas pelo negativo, quando da sua concorrência em outros processos comunicativos para a formação de novos sentidos e também quando da sua utilização como pressuposto para outras comunicações, mesmo fora de programas condicionais de operação do sistema onde é inserido como pressuposto.

Podemos, então, considerar os processos de desvio como falhas no processo de diferenciação durante a ocorrência de operações simultâneas de interpenetrações e/ou interações ocorridas no âmbito da relações entre sistemas sociais, ou seja, na intersecção de processos comunicativos de sistemas acoplados. Nesses casos, o resultado final do processo comunicativo obtido pelo sistema, reconhecidamente sob o funcionamento do código binário próprio do sistema, tem elementos de outros sistemas, resíduos conservados na memória de Alter, em sua formação, sejam (i) informações estruturadas no sistema que influencia, (ii) premissas construídas sobre bases do sistema que influencia ou (iii) resultados esperados em programas do sistema que influencia.

A existência de resíduos de processos comunicativos pode explicar porque os programas dos sistemas sociais geram resultados tão díspares, mesmo em situações iniciais tão próximas, mas que, na verdade, apresentam diferenças importantes - e impenetráveis - que podem direcionar a evolução dos sistemas para caminhos diferentes. Esta idéia já é aceita inclusive na física, mesmo quando ela trata de sistemas fechados, na teoria do caos. Ao contrário do que pode parecer, a teoria do caos não argumenta que os fenômenos naturais não sejam passíveis de mensuração e, portanto, de predição. Nas ciências exatas, a idéia de que os fenômenos são regidos por leis, que poderiam ser transformadas em equações matemáticas, não cai por terra com essa teoria, mas simplesmente o foco muda com o reconhecimento de que há um problema com a capacidade de mensuração exata da posição inicial de determinados sistemas matemáticos não-lineares. Com a ilusão de que dois sistemas estavam na mesma posição, os pesquisadores não conseguiam equacionar os resultados tão diferentes depois de um certo período de tempo. É que estas diferenças são potencializadas a cada nova operação do sistema, transformando aquela diferença inicial até mesmo em direcionamentos diametralmente opostos. Na teoria do caos, isso é chamado de dependência sensível das condições iniciais $^{92}$. Para a física, no entanto, continuaria sendo possível prever os fenômenos naturais, pois que são baseados em equações matemáticas, ainda que a quantidade de cálculos

\footnotetext{
${ }^{92}$ Cf. Mandelbrot, Objetos Fractais, op.cit., p. 45.
} 
necessários para essa predição fosse tamanha, dependendo do número de variáveis e da dificuldade de definição dos pontos iniciais, que, em muitas vezes, a ocorrência do fenômeno viria antes da finalização dos cálculos. Assim, a física não abandona a suposta capacidade de calcular matematicamente os fenômenos caóticos, mas, com a teoria do caos, muda o foco da pesquisa, passando a buscar não mais a previsão dos resultados finais exatos, mas o mapa global dos comportamentos possíveis de determinadas equações não-lineares que representam os fenômenos estudados.

$\mathrm{Na}$ teoria dos sistemas sociais, os sistemas psíquicos, portanto as consciências, não comunicam, mas apenas os sistemas sociais. A existência de processos sobrecomunicativos, no entanto, pode explicar por que as operações dos sistemas sociais são tão imprevisíveis como as consciências. Na formulação do sentido nos sistemas sociais, ainda que haja programas e um código amplamente reconhecido, Alter e Ego podem recuperar resíduos de processos comunicativos de um sistema, com a utilização de parcelas de sua consciência ampliada, e desviar os processos comunicativos de outro sistema com aqueles elementos ${ }^{93}$. Além disso, como na física, as posições iniciais exatas de Alter e Ego nunca podem ser conhecidas, dada a variedade possível de repertórios registrados na consciência ampliada de cada um.

Esta influência de outro sistema, no entanto, não é apenas uma ocorrência decorrente de processos neurológicos e psíquicos. A conformação da organização dos sistemas, de maneira acoplada, é que possibilita esse desvio. Sem o endereçamento simultâneo de um mesmo Alter para dois processos comunicativos de dois sistemas diferentes, com a possibilidade de construção de sentido em ambos, o desvio não seria possível, ainda que Alter fosse sempre o mesmo.

O desvio só é possível porque há algumas estruturas de um sistema à disposição do outro para que os resíduos possam fluir para os processos comunicativos do primeiro.

Para exemplificar os casos de processos sobrecomunicativos resultados de desvios de acoplamento, iremos utilizar três exemplos que acreditamos apresentar a ocorrência de desvios.

\footnotetext{
${ }^{93}$ Esta acepção responde às críticas de que a teoria dos sistemas sociais pode gerar uma imagem válida de sociedade sem homens, já que demonstra que a direção da evolução dos sistemas pode mudar de acordo com seleções e processos comunicativos levados a cabo por pessoas.
} 
O primeiro trata da influência externa de vários sistemas nos processos comunicativos do sistema ciência que ocorrem nas atividades de pesquisa nas universidades e nos institutos de pesquisa $^{94}$. Trataremos especificamente dos processos sobrecomunicativos de desvios originados no sistema economia que influenciam as seleções de Alter, com a questão do financiamento das pesquisas, mas há, para este mesmo caso, exemplos de desvios originados nos sistemas política, arte e educação, entre outros.

O segundo exemplo trata das influências externas sobre o sistema economia, no mercado financeiro, principalmente no mercado acionário. Neste caso, são as atividades em vários sistemas sociais que podem criar "profecias auto-realizáveis", fenômeno típico do sistema economia, mas que contém elementos do sistema política, do sistema intimidade, do sistema ciência, entre outros.

O terceiro e último caso proposto para a exemplificação do conceito é a influência do sistema intimidade sobre o sistema economia e vice-versa no caso das famílias de banqueiros no Brasil. ${ }^{95}$ Ambos os sistemas têm seu funcionamento bastante diferenciado entre si e em relação aos seus respectivos ambientes, mas as interpenetrações e o acoplamento existente exatamente nesta parcela do sistema economia, que são os grandes bancos brasileiros, denotam uma clara ocorrência de processos sobrecomunicativos resultados de desvios de acoplamento.

Em todos estes casos, cabe ressaltar que apenas uma pesquisa detalhada do histórico de cada acoplamento citado poderia dar um panorama mais amplo da ocorrência de processos sobrecomunicativos. O intuito, portanto, é apenas o de apontar alguns exemplos para o evento descrito neste capítulo.

No primeiro caso, dos desvios de acoplamento no sistema ciência, podemos indicar o processo de financiamento das pesquisas como o principal acoplamento estrutural - neste caso com o sistema economia - que gera a possibilidade de desvios de acoplamento. A possibilidade de processos sobrecomunicativos ocorre tanto no sistema público de financiamento de pesquisa, caso mais recorrente no Brasil, quanto no sistema de

\footnotetext{
${ }^{94}$ Luhmann trata de algumas questões que apontamos nesta dissertação em Die Wissenschaft der Gesellschaft, op. cit., pp. 293 e seguintes, mas considera essas ocorrências meros acoplamentos..

${ }^{95}$ Cf. Markowitz, M. Bancos e banqueiros, empresas e famílias no Brasil. Rio de Janeiro, Museu Nacional, dissertação de Mestrado em Antropologia, 2004.
} 
financiamento privado, por meio dos departamentos de P\&D (pesquisa e desenvolvimento) de grandes empresas.

O sistema ciência no Brasil está baseado em grande parte no funcionamento das universidades que, em si, já constituem um sistema à parte, do tipo organização. ${ }^{96}$ É nas universidades que as teorias e as análises científicas são desenvolvidas e é nelas que ocorrem a avaliação e a validação dos discursos e métodos que formam os processos comunicativos do sistema ciência, ou seja, é na universidade que o sistema ciência realiza seus processos comunicativos e também verifica se o código do sistema está funcionando. É na universidade também que o sistema ciência se auto-observa e se descreve, como o que ocorre neste exato momento com este trabalho.

A universidade também é o local onde se desenvolvem processos comunicativos de outros sistemas sociais, como a educação e a política. Por exemplo, por meio do funcionamento da burocracia estatal, o sistema política é responsável por boa parte dos processos comunicativos da universidade, seja a nomeação dos altos comissários, como o reitor e os vice-reitores de cada instituição, seja pela seleção de professores e egressos para cargos nas burocracias municipal, estadual e federal, que tem efeitos na hierarquia e no reconhecimento interno, seja pela relação de mantenedor que o Estado tem com a maioria das grandes universidades, seja pela inserção de elementos de poder presentes nos processos comunicativos do sistema política nos processos de validação científica por meio dos processos sobrecomunicativos. O sistema arte também é responsável por alguns processos comunicativos dentro da universidade, por exemplo, nas relações entre os críticos, membros da organização universidade, e os artistas ou na manutenção e tutela de modelos artísticos acadêmicos pelos programas de cursos de artes instalados na universidade. Há outros exemplos de processos comunicativos de outros sistemas sociais, mas é o caso do sistema economia que interessa para esta análise.

Como quase toda organização, a universidade precisa de um aporte financeiro para seu funcionamento e isto vale tanto para as universidades públicas quanto para as privadas, ainda

\footnotetext{
${ }^{96}$ No Brasil, apesar da existência do Ministério da Ciência e Tecnologia, que administra e mantém os programas de pesquisa científica, é nas universidades que os recursos são distribuídos. Pela Lei Federal n ${ }^{\circ}$ 9.394 (LDB), as universidades são "instituições pluridisciplinares de formação dos quadros profissionais de nível superior, de pesquisa, de extensão e de domínio e cultivo do saber humano". Assim, a própria definição estatal da universidade impõe o acoplamento estrutural entre os sistemas ciência, educação e economia, na organização.
} 
que as fontes sejam diferentes. A pesquisa científica também precisa de aportes financeiros, mas, no caso do Brasil, este aporte vem, em sua grande maioria, do Estado, via universidade cerca de $60 \%$ dos financiamentos vêm do setor público, segundo dados do Conselho Nacional do Desenvolvimento Científico e Tecnológico (CNPq). Este aporte ocorre por meio das bolsas de estudos, dos financiamentos dos programas de pós-graduação, com a montagem de laboratórios, contratações de pesquisadores, disponibilização de orçamentos, etc., eventos que ocorrem na maioria das vezes no âmbito da universidade. A maioria das pesquisas em andamento no país se desenvolve com relativa autonomia dos órgãos de fomento, ligados aos governos e responsáveis pela avaliação dos projetos de pesquisa e dos resultados finais e pelo respectivo financiamento destes projetos.

Em uma análise da burocracia universitária alemã, Luhmann expõe uma situação que não é muito longe da situação da universidade brasileira: "Essa autonomia [do ensino e da pesquisa] não é, inicialmente, um fato jurídico, mas sim fático. Nem o ensino, nem a pesquisa dispõem de uma tecnologia racional - comparativamente à produção industrial. Isso tem consequiências abrangentes. Não é possível comprovar erros, nem distribuir recursos nos montantes necessários para o alcance de êxito ou ao impedimento de falhas, daqueles que trabalham no âmbito dessas funções. Não há dúvida: êxitos e fracassos fazem-se presentes e também são distinguíveis. Mas, em vista da complexidade dos fatores, não é possível definir antecipadamente as condições para tanto. Afinal, a pesquisa deve defrontar-se exatamente com circunstâncias ainda desconhecidas e o ensino com cabeças que dispõem de si mesmas. Ambos excluem receituários seguros. Em virtude da falta de tecnologia suficiente, nesse domínio os processos funcionais não são controláveis mediante a antecipação de premissas. Isso quer dizer: nas centrais não é possível dispor, nem mesmo de forma aproximada, da capacidade de realização. A direção dirige, para retomar a formulação de um reitor universitário americano, uma anarquia organizada" ${ }^{97}$.

$\mathrm{O}$ que, à primeira vista, pode parecer o atestado de autonomia do sistema ciência, atesta, na verdade, a autonomia da organização universidade, responsável por acoplamentos entre os diversos sistemas com os outros sistemas, o que torna os acoplamentos ainda mais importantes, já que eles, na forma de organização - e burocracia - ganham autonomia.

97 Luhmann, N. "Zwei Quellen der Bürokratisierung in Hochschulen". In: Soziologische Aufklärung 4; Westdeutscher, Opladen, 1994 , p. 212-215, trad. Stefan Fornos Klein. 
Além disso, no Brasil, o orçamento destinado à pesquisa é relativamente pequeno, levando em consideração o orçamento de outros países com economias similares, o que torna o problema da escassez de recursos, ou, em outra palavras, os binômios ter/não ter um importante fator no desenvolvimento da ciência - segundo o $\mathrm{CNPq}$, é destinado $1 \%$ do Produto Interno Bruto (PIB) à área de ciência e tecnologia, enquanto a média do grupo de países desenvolvidos é de 3\% do PIB (com o agravante que o PIB destes países é ainda maior do que o do Brasil). A seleção dos projetos e a partição dos recursos obedece a uma hierarquização estratégica, definida pelo Estado $^{98}$ e levada a cabo pela burocracia da universidade (e aqui poderíamos falar do aumento da importância do binômio poder/não poder). Desta forma, alguns projetos de pesquisa consomem grande parte dos recursos disponíveis destinados a este fim. É o caso, por exemplo, do projeto genoma - para o qual foram montados 25 laboratórios espalhados por 15 estados brasileiros - e do programa espacial brasileiro. Além disso, o Ministério da Ciência e Tecnologia conta com 14 programas específicos de pesquisa científica, que, de certa forma, priorizam o setor de tecnologia. Em outra iniciativa governamental, os 17 Institutos do Milênio, do Ministério da Ciência e Tecnologia, predominam os temas de biomédicas e exatas como polímeros, nanociências, matemática, terapia celular, recursos costeiros e genoma.

Essa divisão não impacta as seleções de pesquisadores em potencial de outras áreas do conhecimento científico nos grandes centros urbanos, onde estão localizadas as maiores universidades. Nestas universidades, o pesquisador em potencial na área das ciências humanas, como antropologia, sociologia, história, geografia, arqueologia, lingüística, não seleciona sua área de atuação por conta da partição dos recursos, pois nestes locais estão concentrados os recursos destinados a estas áreas. Mas o mesmo não se pode dizer de localidades com menos recursos, nas quais a maior possibilidade de financiamento da atividade de pesquisa nas áreas de tecnologia acaba atraindo os pesquisadores potenciais.

Essa partição - de um orçamento escasso, que prioriza a área de tecnologia e que aloca desigualmente os recursos - se reproduz horizontal e verticalmente. Ela estabelece uma parcela menor dos recursos para pesquisadores da área das ciências humanas e para as

${ }^{98}$ Neste caso, o acoplamento estrutural entre ciência e política também ocorre em sua grande maioria na universidade, existindo apenas algumas poucas exceções fora deste quadro, como os centros de pesquisa da Embrapa e do Cebrap, por exemplo. Em última análise, no entanto, mesmo estes acoplamentos excepcionais contam com a participação da universidade, já que estas instituições requisitam nos editais de contratação de pesquisadores titulações conferidas pelas universidades. 
universidades de cidades menores, mas também se apresenta no interior das universidades e dos departamentos, definindo uma partição diferenciada entre as diversas unidades de uma mesma universidade, e entre os diversos departamentos de uma mesma unidade.

Dessa forma, por processos sobrecomunicativos de desvio de acoplamento, o pesquisador em potencial de cidades menores está mais propenso a direcionar sua produção inicial para as áreas de tecnologia - que oferece mais oportunidades de remuneração durante a pesquisa científica e também, após as devidas titulações, no mercado de trabalho, produzindo ou não ciência. Da mesma forma, nas universidades maiores, o pesquisador está mais propenso a procurar os departamentos que oferecem mais condições de trabalho e de uma remuneração que possibilite a continuidade da pesquisa científica. Isso pode ser comprovado pelos dados do Institute for Scientific Information (ISI) sobre as áreas da pesquisa nacional que mais publicam nas publicações indexadas no exterior ${ }^{99}$ - que, pelo menos em parte, reflete também as pesquisas que tiveram financiamento mais portentoso: "Considerando toda a produção indexada entre 1998 e 2002, as ciências agrárias lideram esse ranking. Seus artigos representaram 2,96\% da produção mundial nessa área de pesquisa. Em seguida, vieram a física $(2,12 \%)$, a ciência espacial $(1,92 \%)$, a microbiologia $(1,91 \%)$, as ciências de plantas e animais $(1,87 \%)$, a farmacologia $(1,57 \%)$ e a matemática $(1,51 \%){ }^{\prime 100}$.

Sempre há a possibilidade de pesquisadores sustentarem o início de suas carreiras com recursos provenientes de outras fontes, como ajuda dos pais, do cônjuge, herança ou fortuna pessoal - mas isso apenas reforça a interferência externa do sistema economia no sistema ciência por meio de desvios de acoplamento. Isso porque uma grande parte de pesquisadores em potencial, que não dispõe destas fontes alternativas, simplesmente abandona os processos comunicativos do sistema ciência, possibilitando que a composição dos participantes do sistema ciência tenha aumentada o número de pesquisadores com tais fontes alternativas disponíveis.

Ainda que a hipótese de interferência na distribuição dos participantes dos sistema ciência pelo sistema economia nas cidades menores não possa por ora ser fundada em

\footnotetext{
${ }^{99}$ Neste caso, outros fatores interferem na quantidade de publicações e o número de publicações torna-se uma parte de um ciclo virtuoso que não tem um fator único de causalidade, como, aliás, todos os eventos sociais: quanto mais publicação, mais reconhecimento, que por sua vez gera mais financiamentos, que por sua vez sustenta de maneira mais eficiente trabalhos de pesquisa, que por sua vez geram mais publicações e assim por diante. Apenas cerca de $10 \%$ da produção de artigos do Brasil está catalogada no ISI, mas, por ser um comparativo internacional, é uma base de análise representativa.
} 
números, pela mais absoluta falta de dados que possam auferir a distribuição inicial dos pesquisadores potenciais das diversas áreas ${ }^{101}$ - principalmente porque não se tem exatamente o número de pesquisadores em potencial que existiam e existem nos diversos momentos históricos -, podemos analisar situações específicas que explicitam outros exemplos do direcionamento do sistema ciência por interferências externas do sistema economia.

É o caso das seleções de temas, grupos de pesquisa, núcleos de pesquisa, orientadores, linhas de pesquisa e, principalmente, orientação do discurso pela possibilidade de financiamento. Poder-se-ia argumentar que, no Brasil, a atividade de pesquisador seleciona já pela abnegação - dada a falta de recursos. Mas a análise da carreira dos cientistas brasileiros, principalmente da área tecnológica, poderia lançar uma luz sobre o que chamo de processos sobrecomunicativos. Alguns dos momentos nos quais o sistema economia atua sobre o sistema ciência são aqueles em que os projetos de pesquisa são traçados, durante a análise dos editais de seleção dos grupos de pesquisa e nas candidaturas dos pesquisadores. ${ }^{102}$ Algumas linhas de pesquisa, privilegiadas pelas decisões do sistema política, na figura do governo, atraem os pesquisadores, tanto os plenos como aqueles em formação. Definida a linha de pesquisa, desenvolvem-se normalmente os processos comunicativos do sistema ciência - pelo menos até o próximo edital.

Os desvios acontecem ao longo dos processos comunicativos levados a cabo pelos pesquisadores no acoplamento estrutural entre ciência e economia e também durante o funcionamento do programa do sistema ciência, que busca, no ambiente, elementos que têm a capacidade de aumentar a eficácia da sua própria operação.

\footnotetext{
${ }^{100}$ Pivetta. M. "O Salto quântico da Ciência Brasileira”. In: Pesquisa Fapesp, n. 100, jun. 2004

${ }^{101}$ Segundo o CNPq, o Brasil tem cerca de 300 mil mestres e doutores, dos quais entre 60 mil e 70 mil exercem a atividade de pesquisa nas diversas empresas, centros de pesquisa, institutos e congêneres. No ano de 2003, foram titulados cerca de 8.000 doutores no País. Só na Universidade de São Paulo foram mais de 2.000 doutores formados em 2002; na Unicamp, foram mais 750. Estes números são bastante expressivos, dado que a universidade norte-americana que mais formou doutores naquele ano foi a Universidade da Califórnia em Berkley, com cerca de 800 titulações. Isso não significa, no entanto, que todos os pesquisadores em potencial no Brasil seguiram a trajetória da carreira acadêmica e da titulação universitária.

$102 \mathrm{O}$ que chamamos de processos sobrecomunicativos desvios de acoplamento aparece em algumas passagens, por exemplo, das descrições do funcionamento dos programas: "[Os meios de comunicação] são também dependentes do êxito dos programas, que permitem a transformação das condições concretas de atribuição dos valores do código de um medium nos de outro, por exemplo, por meio dos investimentos (dinheiro) podem ser realizadas pesquisas científicas (validade científica). Os media não podem, por outro lado, estar relacionadso de maneira transitiva (o dinheiro não pode se transformar diretamente em validade científica ou em poder) ou hierárquica (o poder não prevalece sobre o dinheiro ou o amor sobre a validade científica). In: Baraldi, Corsi \&Espósito, Glosar, op. cit. p. 195.
} 
O sistema economia interfere nas seleções do sistema ciência, com a avaliação, pelos pesquisadores, de quais editais são mais proveitosos, de quais oferecem mais chances de se obter o financiamento, de quais coincidem as datas de proposição e possível aprovação com suas datas de saída de outros projetos de financiamento etc.

Outro exemplo de processos sobrecomunicativos de desvio de acoplamento que ocorrem entre os sistemas economia e ciência são aqueles que envolvem ainda o sistema política, como as propostas legislativas de (i) isenção de impostos trabalhistas para empresas que contratem doutores como pesquisadores durante os dez primeiros anos após a titulação e (ii) de dedução do Imposto de Renda dos valores doados pelas empresas para atividades de pesquisa e desenvolvimento. Nestes casos, os programas dos diversos sistemas - economia, política e ciência - convergem, o que facilita os processos sobrecomunicativos ${ }^{103}$.

Os pesquisadores ainda realizam, simultaneamente, processos comunicativos de outros sistemas, como a intimidade, quando, em editais de seleção de grupos de pesquisa, seus membros, respeitados os requisitos expressos, são escolhidos com base em conhecimentos prévios e em laços de afetividade com o líder, ou líderes, dos grupos.

Da mesma maneira, poderíamos levantar a questão da comunicação em massa, quando trata de ciência. É difícil acreditar que pesquisadores não gostariam de atingir o maior número possível de interlocutores, de informar o maior número possível de pessoas sobre suas descobertas - e não há qualquer juízo de valor aqui embutido, já que isto poderia provir tanto de um sentimento altruísta, a fim de informar a população sobre algo importante para suas

\footnotetext{
${ }^{103}$ Luhmann considera estas ocorrências meros acoplamentos estruturais: "Se obtém então a explicação que os aportes das prestações (outputs) sempre se realizam utilizando o código do sistema que aporta, isto é, realizam-se como uma operação interna deste último. Assim, o pagamento em dinheiro segue sendo uma operação do interior da economia (isto é, limitado à contínua utilização do dinheiro como meio de pagamento), ainda que seja utilizado para a remuneração da atividade de pesquisa. $\mathrm{O}$ sistema ciência não tem a capacidade de processar dinheiro diante da decisão pagar/não pagar, não pode chegar à confirmação da verdade ou da falsidade. Isto não exclui a compreensão trivial de que muitas pesquisas não ocorreriam se não se pagasse por elas. Há, no entanto, apenas um acoplamento estrutural, que não admite nenhuma sintonização exata (um euro por uma verdade!). E ainda quando no processo de acoplamento o observador pode reconhecer apenas uma única comunicação, por exemplo, pesquisas eleitorais como comunicação científica e política, para reconhecer isto deve-se distinguir os dois sistemas para poder observar em ambos, separadamente, as intermediações e as conseqüências." (Luhmann. Die Wissenschaft der Gesellschaft, op. cit. p. 638) O presente trabalho objeta esta simplificação, propondo que mais do que um mero acoplamento estrutural, onde o observador pode "observar separadamente em ambos as consequiências do acoplamento", e menos do que uma "sintonização exata: um euro por uma verdade". Trata-se de uma situação intermediária, onde os sentidos dos processos comunicativos não podem ser observados nos dois (ou mais) sistemas, aí incluídos os sentidos propostos e assumidos pelos sistemas psíquicos que tomam parte neste processo comunicativo, no exato momento em que ocorrem. Não se traduz um euro em uma verdade, mas os processos comunicativos que assumem o euro - ou o real ou o dólar - como elemento significativo podem
} 
vidas, como de um sentimento egoísta, a fim unicamente de capitalizar popularidade e prestígio. Dificilmente um projeto de pesquisa é montado já levando em consideração os processos comunicativos do sistema comunicação em massa, mas, em determinados momentos da pesquisa, isto pode ser um fator a ser considerado, o que pode levar os pesquisadores a realizar seleções a fim de maximizar o impacto, ou a exposição de sua pesquisa nestes mesmos meios. ${ }^{104}$

Nosso segundo exemplo trata das influências externas sobre o sistema economia, principalmente no mercado financeiro, que engloba os mercados futuros e os mercados de ações. Os processos sobrecomunicativos resultados de desvios de acoplamento, neste caso, podem ser expressos pelas "profecias auto-realizáveis", fenômenos típicos do sistema economia, que consistem na concretização de expectativas quanto à precificação dos diversos ativos econômicos, como moeda, títulos públicos, ações, entre outros, causada exatamente pela crença de que aquilo ocorrerá, porque os movimentos de negociação destes ativos - pelo funcionamento da lei da oferta e da procura - derruba os preços quando muitos acham que o ativo vai se desvalorizar e começam a vender os seus ou faz subir os preços quando muitos acham que o ativo vai se valorizar e começam a comprar estes ativos para ganhar com a valorização e se recusam a vender pelos mesmos motivos. Dessa forma, no mercado financeiro, as expectativas produzem valor de maneira mais direta e rápida à medida que os diversos negociadores direcionam, em grande escala e simultaneamente, seus processos comunicativos no sentido proposto pela expectativa, reforçando-a. Estas expectativas são classificadas na teoria dos sistemas sociais como ruídos e muitos autores sustentam que são, inclusive, o que torna o mercado financeiro atrativo, e não a produção de lucro. O que tornaria incluídos no sistema os participantes que conseguem decodificar estes ruídos e perceber a construção de sentido a partir deles. ${ }^{105}$

orientar o modo e o direcionamento da produção de verdades a partir das seleções dos pesquisadores, que trazem sentidos dos processos comunicativos do sistema economia para o sistema ciência.

${ }^{104}$ Processos comunicativos do sistema política já levam em consideração os processos comunicativos do sistema de comunicação de massa há muito tempo. Tanto os discursos políticos, quanto as votações nas casa legislativas e também a proposição de leis e medidas provisórias são precedidos de enquetes, sondagens e de um estudo minucioso do cronograma dos noticiários.

${ }^{105}$ Cf. Stäeli, U. "Financial Noises: Inclusion and the Promise of Meaning". In: Soziale Systeme, número 9 , caderno 2, pp. 244-256. 
Não se pode negar a importância do ruído na produção de sentido ${ }^{106}$, mas o fato de que a decodificação destes ruídos é exatamente o que produz o sentido de determinado sistema leva à consideração de que o acoplamento estrutural, neste caso, é responsável por algo mais do que fonte de informação para os processos comunicativos internos. Em relação a isso, é significativo lembrar que os departamentos de análise do mercado financeiro das grandes gestoras de recursos - ligadas ou não a bancos - são compostos não apenas de analistas financeiros, mas também de analistas especializadas em estudar relatórios, leis, movimentos de consumo e relações internacionais, a fim de antecipar o conhecimento dos efeitos dos ruídos dos mais diferentes sistemas sobre o mercado financeiro.

Se estar incluído é decodificar os ruídos e perceber como eles produzem sentido dentro do sistema economia, os mesmos participantes que conseguissem prover essa decodificação e que participassem também de outros sistemas poderiam produzir nos respectivos sistemas os ruídos necessários aos seus interesses no sistema economia. ${ }^{107}$ Não se trata, porém, dessas interferências de que vamos falar para expor a questão das profecias auto-realizáveis, mas dos processos sobrecomunicativos que ocorrem no momento da definição do investimento pelo aplicador dos diversos países.

No Brasil, os investimentos no mercado financeiro da grande maioria das pessoas são realizados via gerente da agência do banco onde o investidor mantém sua conta corrente, persistindo a prática mesmo entre alguns grandes investidores, principalmente no interior do país. Na maioria dos casos, este grande contingente de investidores não dispõe de analistas especializados para adiantar as "profecias", com a análise de dados agregados, relatórios, etc. e os investimentos são realizados a partir (i) da indicação do gerente do banco ou (ii) do repertório próprio de informações, composto de muitos resíduos de processos comunicativos de vários sistemas. Dessa forma, estes investidores tomam conhecimento do movimento geral no meio ou no final do ciclo. ${ }^{108}$ Essa conjunção de fatores interfere de duas maneiras no

\footnotetext{
106 Para mais detalhes ver: Rasch, Niklas Luhmann's Modernity: The Paradoxe of Differentiation, op.cit. e Serres, M. Le Parasite. Paris, Grasset, 1980.

107 Em muitos casos isso realmente acontece, o que poderíamos inclusive classificar como processos sobrecomunicativos resultados de observação continuada, que ocorrem pelo menos desde o século XVIII, quando o agente de investimento de Luís XV, John Law, espalhou boatos sobre a criação de um banco real em Paris, no início daquele século e, dado o frenesi especulativo, teve que fugir do país em 1720 (Cf. Staeli. "Finacial Noises", op. cit., p. 247).

${ }^{108}$ Estes investidores acabam por perder dinheiro, pois começam a vender seus ativos depois de o preço já ter caído bastante ou começam a comprar ativos depois de o preço já ter subido bastante, neutralizando a possibilidade de o investidor ganhar com um processo de valorização que já finalizou.
} 
desenvolvimento dos processos comunicativos do sistema economia, nos momentos em que os investidores selecionam e realizam suas operações.

A primeira é o reforço de mitos ${ }^{109}$ sobre o mercado financeiro, informações que estes investidores utilizarão para realizar seus próximos investimentos e que, não necessariamente, têm a ver com os processos comunicativos do sistema economia, mas cuja fundamentação está erroneamente baseada em resultados inequívocos do sistema economia. ${ }^{110}$ Esses mitos podem ser expressos por "certezas" decorrentes das experiências em situação de pouca informação no mercado financeiro, que tenham causado um prejuízo no mercado acionário, por exemplo, ou por conselhos de amigos ou parentes, igualmente desinformados, sobre certas decisões de investimento.

A segunda é a utilização de sentidos válidos em outros sistemas para a seleção de processos comunicativos no sistema economia, por exemplo, nas relações de intimidade nas quais as sugestões de investimento são feitas, nas relações de família, nas quais um determinado tipo de investimento é valorizado - no Brasil a questão da propriedade mobiliária é o maior exemplo disto - nas relações de seleções pessoais baseadas em resíduos comunicativos do ambiente do sistema economia, como presença na mídia da empresa cujas ações, por exemplo, se negocia, ou a imagem de avanço tecnológico que certas empresas podem gozar junto ao público. Assim, os investidores, no momento em que realizam seus investimentos e no momento em que se desfazem deles, liquidando seus títulos, também participam simultaneamente de processos comunicativos em outros sistemas ou trazem em seu repertório resíduos de processos comunicativos de outros sistemas, gerando a ocorrência de processos sobrecomunicativos de desvio de acoplamento.

Da mesma forma que processos comunicativos de outros sistemas podem influenciar a economia no funcionamento do mercado financeiro, o mesmo mecanismo pode ser observado em outras situações do mesmo sistema, quando da seleção de certas "tecnologias" para o lançamento comercial - principalmente na área da saúde, onde o consumo é ainda mais suscetível ao apelo tecnológico, como a grande maioria dos medicamentos, os aparelhos de estética, etc. - ou do desenvolvimento de alguns hábitos de consumo em detrimento de outros,

${ }^{109}$ Para mais detalhes ver: Clements, J. Os mitos que você deve evitar se quiser administrar corretamente seu dinheiro. São Paulo, Letras\&Lucros, 2003. 
ocasionado por seleções de fora do sistema economia, sejam seleções fundamentadas por escolhas aleatórias - e neste caso provavelmente com a presença de resíduos de processos comunicativos de outros sistemas ${ }^{111}$-, ou realizadas diretamente a partir das seleções de outros sistemas, como as do meio de comunicação em massa, por exemplo. ${ }^{112}$

O terceiro e último caso a ser apresentado para exemplificar o funcionamento dos processos sobrecomunicativos resultados de desvios de acoplamento é o da influência do sistema intimidade sobre o sistema economia e vice-versa no caso das famílias de banqueiros no Brasil. As trajetórias econômicas dos três maiores bancos brasileiros, Bradesco, Itaú e Unibanco, foram resultado de influências da organização de cada uma das famílias, ou grupos de famílias, controladoras no que diz respeito às seleções de parcerias, áreas e formas de atuação destas instituições na economia do país. ${ }^{113}$

Poder-se-ia objetar este exemplo sob o argumento de que a propriedade em muitos aspectos organizava-se sob a estrutura das famílias em sociedades arcaicas, que não se diferenciavam e que, então, a influência poderia ser devida à falta de autonomia destes sistemas, talvez com a ocorrência de alopoiése. Mas o exemplo trata de três dos 600 maiores

\footnotetext{
${ }^{110} \mathrm{O}$ investidor, por exemplo, que investe em ações no final de um ciclo de valorização e perde dinheiro, assume que investimentos em ações levam necessariamente a prejuízos, sem levar em consideração que aquele resultado tem a ver com determinado evento ocorrido fora do sistema economia.

${ }^{111}$ É o caso das seleções de consumo de determinadas marcas e não outras, da frequiência em determinados estabelecimentos de entretenimento noturno, bares, boates e assemelhados e não em outros. Em ambos os casos é difícil falar em diferença qualitativa mensurável economicamente. Tome-se o exemplo da abertura de estabelecimentos de entretenimento noturno em grandes cidades, cujo sucesso ou fracasso depende em grande parte de seleções realizadas fora do sistema economia, dos cálculos de fornecedor, público alvo, faturamento, entre outros. Ainda que empresários realizem sondagens e aproveitem a existência dos clusters de bares e boates - bairros de concentração destes estabelecimentos - seus sucessos financeiros dependem, em grande parte, de seleções aleatórias dos consumidores, que são realizadas nos acoplamentos entre diversos sistemas que compõem seus comportamentos, inclusive o econômico, e, provavelmente, são realizados com a presença de resíduos de processos comunicativos de outros sistemas, como a intimidade, sob a indicação de amigos e parentes, por exemplo.

${ }_{112}$ Os hábitos de consumo de produtos determinariam um estudo à parte na descrição dos processos sobrecomunicativos, já que a seleção dos produtos que serão consumidos e, conseqüentemente, de sua produção são determinados sob complexos processos sobrecomunicativos baseados em resíduos de processos comunicativos de vários sistemas. Uma importante parcela da criação na área da propaganda procura mapear estes resíduos expressos em preferências, desejos, propensões e rejeições dos consumidores. Para ver mais detalhes: Sant'Anna, A. Propaganda: Teoria - Técnica - Prática. São Paulo, Thomson Learning, 1998; Gade, C. Psicologia do Consumidor e da Propaganda. São Paulo, Editora Pedagógica e Universitária, 1998; Solomon, R. O Comportamento do Consumidor. Porto Alegre, Bookman, 2002. Atualmente a maioria dos lançamentos são precedidos de pesquisas que tentam auferir empiricamente a expressão destes resíduos - sem, no entanto, preocuparem-se em descrever os processos de formação destas preferências.

${ }^{113}$ Cf. Markowitz, M. Bancos e banqueiros, empresas e famílias no Brasil, op. cit.
} 
conglomerados econômicos do mundo, que lucraram juntos, em 2004, R \$ 8,1 bilhões ${ }^{114}$ e que tem capital aberto - o Bradesco desde 1946, o Itaú desde 1944 e o Unibanco desde 1968 -, contando com auditorias independentes e milhares de acionistas, o que afasta a possibilidade de se tratar de empresas organizadas sob condições arcaicas de administração e gestão e sem os limites sistêmicos. Além disso, trata-se de dois sistemas que têm suas fronteiras claramente definidas, com a existência autônoma, do ponto de vista sistêmico, dos respectivos conselhos de administração profissionalizados, diferenciados funcionalmente das respectivas famílias controladoras.

Mesmo assim, a influência de um sistema sobre o outro ocorreu por meio de processos sobrecomunicativos entre os sistemas intimidade e economia. Os momentos em que estes processos ocorreram vão desde a gênese dos bancos, passando por vários momentos de formação de laços de amizade entre seus controladores e outras famílias ou membros do governo - o que ensejaria um trabalho inteiro para definir os processo sobrecomunicativos entre o sistema economia e o sistema política no processo de desenvolvimento destas empresas - e chegando ao momento da organização estrutural do organograma destes bancos, quando foi definida a participação das famílias nos processos decisórios dos conselhos de administração.

No caso do Bradesco, o controlador Amador Aguiar tinha uma relação de amizade com José da Cunha Jr., genro de José Galdino de Almeida, dono da Casa Bancária Almeida, o que viria a se tornar em 1943 o Bradesco. Aguiar torna-se presidente do banco em 1969. O estilo puritano e austero de Aguiar, que professava o presbiterianismo, criou algumas situações que definiram decisões econômicas da empresa que controlava. Em primeiro lugar, era o exemplar do self made man, que valorizava o trabalho e a organização. Em segundo, estabelecia regras rígidas de comportamento na sede do conglomerado, o que impediu, por exemplo, a fusão com o banco Unibanco no início da década de 70 , porque o presidente do Unibanco, em uma visita para tratar do assunto, foi barrado na porta do conglomerado por usar cabelos compridos, proibidos pelas normas internas. Não que a decisão de não realizar a

\footnotetext{
114 Segundo a Revista Forbes, de 02 de abril de 2005, o Bradesco figura em $208^{\circ}$ lugar, o Itaú em $477^{\circ}$ e o Unibanco em $601^{\circ}$ entre as maiores empresas do mundo em um ranking elaborado a partir de dados de faturamento, lucros, ativos e valor de mercado. Ainda que este ranking não leve em consideração apenas a empresa financeira dos respectivos grupos, nos três casos, elas são o carro chefe dos conglomerados. Segundo os balanços de 2004, o banco Itaú lucrou R\$ 3,776 bilhões, o Bradesco, R \$ 3,060 bilhões e o Unibanco, R \$ 1,283 bilhões.
} 
fusão tenha sido uma retaliação, mas o evento deixara patente a diferença de estilos das duas instituições.

Do mesmo modo, na década seguinte, diferenças pessoais, que contudo não chegaram a se constituir em um conflito aberto, fizeram ser desfeita a parceria com o amigo Antonio de Almeida Braga ${ }^{115}$, dono da seguradora Atlântica, que por meio de uma troca de ativos, assumira presidência do banco durante a parceria. Segundo Almeida Braga, Aguiar era muito pudico e ele queria "aproveitar melhor a vida". O estilo de vida diferenciado também causou o fim da parceria entre Aguiar e os controladores da Seguradora Sul América no mesmo ano.

A sucessão do Bradesco, depois da morte de Aguiar e da curta presidência de um executivo de sua confiança mas de idade avançada, também foi marcada pela influência de processos comunicativos do sistema intimidade. Aguiar não deixou herdeiros homens, o que impediu a sucessão direta - por uma certa tradição arraigada na família brasileira, pelo menos até o terceiro quartel do século passado, de não formar as mulheres para os cargos de direção. Além disso, houve uma briga judicial entre suas três filhas adotivas e sua segunda esposa, muitos anos mais nova do que ele, pela herança de Aguiar, ao mesmo momento em que ocorria no banco uma guerra pela sucessão do controlador. O desfecho desta situação talvez produza o fim dos processos sobrecomunicativos do sistema família sobre o sistema economia neste caso, pois os dois netos de Aguiar estão afastados das atividades do banco, apesar de continuarem sendo os acionista principais e a nova diretoria empossada foi totalmente profissionalizada e tornada impessoal.

Já o Unibanco, que começou em 1924 também como uma casa bancária, teve seu desenvolvimento influenciado pelos laços de amizade formados em Poços de Caldas - cidade onde estava localizada a casa bancária - entre os controladores da família Moreira Salles e vários personagens da elite brasileira. No período entre guerras, a cidade foi o balneário da elite do país, atraindo tanto turistas quanto pacientes de diversas enfermidades que se queriam tratar em suas águas termais. Com a situação da Europa naquele período, que não oferecia segurança para os turistas brasileiros abastados, Poços de Caldas era um destino bastante procurado por este público.

A intimidade dos controladores do Unibanco com o poder era grande, por exemplo, Walther Moreira Salles, o primogênito do fundador do banco, namorou a filha do então 
presidente da República na época, Getúlio Vargas. Quando Vargas é eleito para o seu segundo mandato como presidente, em 1950, indica Walther Moreira Salles como superintendente da SUMOC (Superintendência de Moeda e Crédito, embrião do futuro Banco Central). Os laços de amizade de Moreira Salles, que também atuou como embaixador - um outro front de relações pessoais proveitosas no sistema economia -, também incluíam pessoas que iriam ser grandes empresários das finanças internacionais - principalmente judeus fugidos da Segunda Guerra Mundial que conhecera em Nova York e no Rio de Janeiro - e da mídia, como a futura esposa do dono da Rede Globo de Comunicações, Lilly de Carvalho.

As escolhas pessoais dos filhos de Walther Salles, dos quais apenas um finalizou seus estudos na área de Economia, podem ainda vir a determinar o direcionamento futuro do banco, já que não há representantes da família controladora nos principais cargos do banco, ao contrário do Itaú.

O Itaú, por sua vez, foi formado a partir da família Egydio Souza Aranha, cujas mulheres se casaram com homens das famílias Villela, Setúbal e Monteiro de Carvalho. Os principais aspectos dos processos sobrecomunicativos neste caso provêm (i) da formação técnica dos respectivos maridos, que direcionam o capital do banco para empresas de tecnologia coligadas, que formam parte importante do conglomerado e (ii) da formação de uma geração de cinco filhos homens da família Setúbal, preparados para controlar o banco, ainda que a participação desta família seja menor hoje do que a da família Villela, que não tem membros na diretoria da instituição. ${ }^{116}$

Nesses três casos, podemos descrever os processos sobrecomunicativos como desvios mútuos e sucessivos de acoplamento entre o sistema família e o sistema economia, tornados possíveis tanto pela coincidência dos participantes de um e de outro sistema, levando a cabo processos comunicativos de ambos, como pela convergência dos programas de um e de outro sistema - muitas vezes confundindo-se estes programas: manutenção da família, por conseguinte de seus meios de vida, e manutenção da empresa.

Nestes casos, seria tentador defender que os sistemas comunicativos de um e de outro sistema eram autônomos e sem interferência mútua, já que não podemos identificar os

\footnotetext{
${ }^{115}$ Braga fora casado com uma neta de Joaquim Nabuco e sido sócio do ex-governador da Guanabara, Carlos Lacerda.

116 Cf. Markowitz, M. Bancos e banqueiros, empresas e famílias no Brasil, op. cit., que descreve minuciosamente o histórico abordado de forma sintética nas páginas anteriores.
} 
momentos exatos em que um e outro sistema tomam as premissas do outro para suceder seus próprios processos comunicativos. Mas o fato de não podermos apontar este momento exato, não nos impede de identificar seus traços, tanto no desenvolvimento de um quanto no de outro sistema.

Os exemplos deste trabalho servem apenas para ilustrar a existência destas interferências externas, mas a identificação e descrição minuciosa de cada processo sobrecomunicativo demanda um trabalho de análise empírica dos sistemas acoplados, da reconstrução histórica detalhada, isto é, o histórico das operações do sistema, e da investigação dos rastros destes eventos. Em muitos casos, essa reconstrução pode não mais ser possível, seja porque os rastros desapareceram e não há mais como reconstruir todos os processos comunicativos que tomaram forma naqueles sistemas acoplados, seja porque não se consegue descrever os antigos limites destes sistemas, impossibilitando a referência do que era processo comunicativo de um e o que era de outro. Isto sugere que a descrição e a investigação dos processos sobrecomunicativos limita-se por aspectos temporais e documentais, sendo possível realizar este trabalho sobre processos que ainda estão ocorrendo ou sobre processos que apresentem documentação farta e detalhada. 


\section{V - CONCLUSÕES}

Luhmann realizou um salto epistemológico importante ao inserir a contingência, a improbabilidade e o paradoxo como elementos da própria teoria sociológica e ao desenvolver a idéia de sistemas fechados operacionalmente e abertos cognitivamente, superando, assim, tanto a dicotomia entre sistemas hermeticamente fechados e sistemas abertos e indiferenciados, como a dificuldade dos clássicos em explicar o caráter extremamente fragmentado da sociedade moderna.

Com uma extensa pesquisa, que levou a cabo por cerca de 30 anos, o sociólogo alemão elaborou uma teoria abrangente, totalizante e desafiadora. A ambição inicial, de elaborar uma teoria geral da sociedade, foi plenamente alcançada e, atualmente, a teoria dos sistemas sociais tem potencial para se tornar um clássico, não no sentido que Luhmann criticava - de tradição arcaica -, mas no de estabelecer paradigmas de análise da sociedade. O alcance da teoria é universalista e, como tal, aspira a poder explicar todas as relações sociais, contemporâneas e passadas, sob o ponto de vista sistêmico. É verdade que o desenvolvimento da teoria foi mais voltado para a explicação da sociedade contemporânea, diferenciada funcionalmente, à qual Luhmann chamava de moderna, mas os instrumentos da teoria estão à disposição de pesquisadores de várias áreas do conhecimento - desde antropologia e arqueologia, até economia e administração, entre outros -, para que passem a analisar com outras lentes os objetos, ou sistemas - inseridos ou não na modernidade -, a que dedicam sua atenção.

Ao mesmo tempo em que oferece instrumentos para o desenvolvimento teóricosistêmico de outras ciências - assim como trouxe de outras ciências alguns de seus próprios elementos e inspiração - a teoria dos sistemas sociais ainda é uma teoria em desenvolvimento

dentro da sociologia. O trabalho realizado por Luhmann, com a elaboração do núcleo essencial, dos conceitos-chave e do arcabouço geral, foi excepcional, mas ainda há muitos caminhos a serem analisados e experimentados na evolução da teoria. E o das relações intersistêmicas é um deles. Isso, ao contrário do que pode parecer, não é uma falha, mas uma qualidade da teoria, que se mantém aberta para avanços ulteriores.

É neste sentido que o presente trabalho apresentou o conceito de processos sobrecomunicativos. Identificando a questão das relações inter-sistêmicas, em particular no 
funcionamento dos acoplamentos estruturais, como a chave para a compreensão das possibilidades de explicação do desenvolvimento diferencial e contingente dos sistemas, ao mesmo tempo em que ocorrem interferências externas nesses mesmos sistemas sem prejuízo de sua autopoiése; o trabalho procurou descrever como essas relações podem ocorrer.

O diagnóstico do tema das relações inter-sistêmicas como janela de expansão da teoria não é original - os chamados pós-luhmannianos, que trabalharam diretamente com Luhmann em Bielefeld durante a elaboração da teoria dos sistemas e que continuam a desenvolvê-la, identificaram o tema e alguns encaminhamentos foram propostos. $\mathrm{O}$ presente trabalho, no entanto, segue um caminho particular. Ao invés de categorizar as influências externas a partir de esquemas rígidos, que as vinculam a um determinado tipo de sistema ou de desenvolvimento sistêmico, este trabalho propôs o conceito de processo sobrecomunicativo, levando em consideração sua ocorrência diária e corriqueira. Assim, como no caso dos pósluhmannianos, existe o reconhecimento de interferências planejadas, no caso dos processos sobrecomunicativos resultados de observação continuada, mas também há o reconhecimento original de interferências conjunturais, os processos sobrecomunicativos resultados de desvios de acoplamento.

Os dois conceitos procuram ampliar a capacidade explicativa da teoria dos sistemas sociais sem, no entanto, romper com nenhum de seus pressupostos básicos, como a autopoiésis do sistema ou o fechamento operacional. Assim como os conceitos desenvolvidos inicialmente na teoria dos sistemas foram capazes de explicar um número muito maior de aspectos da sociedade moderna, que não eram mais passíveis de explicação a partir das teorias clássicas, esperamos que o conceito de processo sobrecomunicativo auxilie na explicação de outros fenômenos que, até agora, estavam fora da abrangência da teoria, por exemplo as atividades de planejamento dos diversos sistemas acoplados na sociedade.

Luhmann executou muito bem a resolução teórica do diagnóstico da improbabilidade comunicativa, da virtualidade e da contingência da vida moderna, que aparecem já expressos em fragmentos artísticos da modernidade, como nos poemas de Manuel Bandeira. Além disso, os conceitos luhmannianos caem como uma luva para a observação da realidade dos processos comunicativos dessa modernidade e superam as dificuldades de explicação das teorias clássicas. 
O diagnóstico da improbabilidade comunicativa e seu encaminhamento teórico, no entanto, criaram um problema com o qual se batem os pós-luhmannianos e também este trabalho: a dificuldade de explicar o êxito de parte dos planejamentos que se observa empiricamente na sociedade e também a insistência da inversão de muitos processos comunicativos de um sistema nos de outro.

A proposição do conceito de processo sobrecomunicativo é uma tentativa de buscar respostas a essas questões. Antes de ser o fechamento de um projeto de pesquisa, é, dessa forma, o início de desenvolvimentos que podem levar a um refinamento da teoria possibilitando a análise dos mais variados tipos de influências externas em relações intersistêmicas, tais como as relações médico-paciente - que poderiam ser analisadas como um processo sobrecomunicativo de observação continuada em atendimentos de medicina de família, por exemplo -, as relações aluno-professor no sistema educacional, os planos de governo, a formação de mitos nacionais, a propaganda, entre outros.

Como já não contamos com a presença de Luhmann, temos que substituir os seus possíveis esclarecimentos sobre elementos da teoria por uma observação acurada dos conceitos já desenvolvidos, pela proposição de explicações criativas e rigorosas da realidade e pela observação atenta desta mesma realidade, a fim de reconhecer as marcas que delineiam os limites entre os sistemas, os elementos que formam suas operações e os elementos que formam os processos comunicativos - e os sobrecomunicativos - dos vários sistemas sociais.

Da mesma maneira, é necessário desenvolver a terminologia da teoria, ainda em desenvolvimento, observando o rigor, a apropriação e a consistência da linguagem e da análise, bem como estabelecer um diálogo franco com as possibilidades que outras ciências oferecem à sociologia para a ampliação da capacidade de análise, além de prover o debate para o filtro das idéias mais consistentes. Foi essa a linha que guiou a elaboração deste trabalho. 


\section{VI - ANEXO}

O conceito de acoplamento estrutural substituiu, no desenho geral da teoria dos sistemas sociais, o antigo conceito parsoniano de interpenetração. Luhmann utilizou a interpenetração no esboço da teoria apresentado em Soziale Systeme (1984), mas em Die Wissenschaft der Gesellschaft, de 1990, já utilizava o conceito de acoplamento - sem prejuízo da utilização da idéia de interpenetração para um caso específico de acoplamento.

Desde então, Luhmann passou a aumentar a atenção dada aos acoplamentos estruturais, dedicando em Das Recht der Gesellschaft (1995), em Die Gesellschaft der Gesellschaft (1998) e em Die Politik der Gesellschaft (2002 - póstumo), a cada vez, um capítulo para esse conceito, como já havia feito com o conceito de interpenetração, em Soziale Systeme. Nesta obra, inclusive, Luhmann já começa a apresentar o esboço do que seria posteriormente o conceito de acoplamento estrutural, no capítulo onde apresenta o conceito de estrutura.

O que segue como anexo a este trabalho é uma tradução do capítulo "Acoplamentos Estruturais" presente em Die Politik der Gesellschaft, o último dos livros citados. Como a tradução para a língua portuguesa de Das Recht der Gesellschaft está em andamento e deve ser lançada em breve, pouco vai faltar ao público brasileiro para ter à disposição parte considerável do material produzido por Luhmann a respeito desse conceito.

Muitos dos exemplos utilizados por Luhmann no texto poderão parecer vagos para os leitores brasileiros, tais como os exemplos da campanha cultural por uma menor intervenção estatal no sistema educacional, ou o da politização das Gesamtschüle, instituições educacionais que englobam desde o ensino fundamental até o ensino superior, ou ainda o das estruturas de aconselhamento e da grande difusão de conselheiros especialistas (Berater) na sociedade alemã e o do problema de imigração como um importante ponto da política. Ainda assim, no entanto, o contato com o texto de Luhmann é essencial para o desenvolvimento do debate acerca da teoria dos sistemas sociais no Brasil, pois há muito o que se extrair diretamente de sua obra.

Texto original: "Strukturelle Kopplungen”, In: Die Politik der Gesellschaft, Frankfurt a.M., Suhrkamp, 2002, cap. X, pp. 372-405 


\section{Acoplamentos Estruturais}

I

(//372) Não resta nenhuma dúvida de que a política se realiza na sociedade. Tampouco se pode duvidar que a sociedade pressupõe um mundo real, no qual ela se pode fechar operativamente e com isso se reproduzir autopoieticamente. O correspondente vale para todos os sistemas autopoiéticos e também para aqueles aos quais se pode subordinar uma compreensão cognitiva do ambiente. Entretanto, é de se observar que toda cognição exige uma construção de diferenças internas do sistema, portanto operações internas do sistema. De outra maneira, ela não pode dar lugar à informação e à produção de informações. Mas isto não altera em nada o fato de que é necessário observar o fechamento operacional como condição de cognição; pois apenas graças a uma interrupção da concordância ponto a ponto de estados externos com estados internos, é possível que um sistema aprenda a se orientar por formas (assim, sempre na diferença de alguma outra coisa). A orientação pela diferença significa um grande aumento das possibilidades de pontos de vista, nas quais poderia ser relevante que o ambiente apenas fosse realizável se o contato direto com o ambiente fosse interrompido. Então, só assim pode surgir o que para nós é evidente e usual como uma experiência sensorial.

O fechamento operacional, portanto, não pode significar jamais que um sistema autopoiético opera como se não houvesse nenhum ambiente; e, com mais razão, deve-se rejeitar a completa e absurda representação extremada de que, com a teoria da autopoiése, estão excluídas hipóteses de existência. O fechamento operacional significa, entretanto, que a cognição supõe uma determinada forma, para a qual não há correspondências no ambiente, a saber, a forma da designação de alguma coisa na diferença em relação a outras. ${ }^{117}$ Sem esta forma (//373) não é possível nenhuma cognição; graças a essa forma, porém, podem operar um sistema psíquico, ou um sistema social, simultaneamente fechados operacionalmente e abertos cognitivamente, quando o sistema executar um "re-entry" da forma na forma, isto é,

\footnotetext{
${ }^{117}$ Ver também Luhmann, N. Erkenntnis als Konstuktion (Conhecimento como construção), Bern, 1988; e, do mesmo, Wirtschaft der Gesellschaft (Economia da Sociedade), Frankfurt, 1990.
} 
se for possível orientar as próprias operações (as quais permanecem inacessíveis ao ambiente) na distinção da auto-referência e da referência externa. ${ }^{118}$

A emergência de sistemas autopoiéticos tem conseqüências para suas relações com o ambiente. Estas relações não podem, ou, em todo caso, não diretamente, depender da cognição, pois a cognição processa apenas construções internas. A este respeito, o assim chamado construtivismo radical encontra-se em uma oposição frontal a todas as teorias tradicionais do conhecimento (e isto sem qualquer renúncia ao "Realismo"). A adaptação de um sistema autopoiético às condições do ambiente são mediadas pelos Acoplamentos Estruturais, que apenas irritam os processos cognitivos do sistema, mas não podem determiná-los. Eles se tornam perceptíveis em comparação com expectativas dadas, ou seja auto-produzidas, disponíveis para a reprodução de estruturas perfiladas, mas não como definição de estados futuros do sistema. Acoplamentos estruturais são, portanto, plenamente compatíveis com a autopoiése dos sistemas; eles (os acoplamentos estruturais), porém não a limitam (a autopoiése), mas se utilizam dela a fim de fazer valer, apesar disso, as condições do ambiente. ${ }^{119}$ Uma multiplicidade de acoplamentos estruturais (//374) fortalece, por isso, também a autonomia do sistema.

Destes fundamentos da teoria dever-se-á esperar que os acoplamentos estruturais sejam sempre estruturados de maneira altamente seletiva, portanto, que excluam muito mais do que incluam, mais exclusivo quanto mais fechado. Isso pode dar-se a conhecer, por exemplo, pelos olhos e ouvidos, os quais conseguem intermediar as irritações do cérebro por uma ligação física muito estreita. O mesmo se aplica, sob condições modificadas, para o sistema de comunicação sociedade. A sociedade pode ser irritada apenas através da consciência, portanto nem biologicamente, nem quimicamente nem fisicamente.

\footnotetext{
${ }^{118}$ Um matemático formula a conexão (que para ele é simultaneamente o ponto de partida de uma teoria matemática) como segue: "Qualquer distinção envolve a auto-referência daquele que distingue. Por isso, autoreferência e a idéia de distinção são inseparáveis (por essa razão conceitualmente idênticos). Nós exploramos a auto-referência examinando o que aparece para nós como distinção" (Kauffman, L. H. "Self-reference and recursive forms". In: Journal of Social and Biological Structures, n. 10, 1987). Falta apenas acrescentar que, por conseguinte, também a auto-referência pode ser designada na diferenciação em relação à referência externa.

119 Para este conceito vide Maturana, H. Erkennen: Die Organisation und Verköperung Von Wirklichkeit: Ausgewählte Arbeiten zur biologischen Epistemologie (Reconhecer: A organização e representação da realidade: trabalhos selecionados de Epistemologia Biológica), Braunschweig, 1982. Que este conceito seja gerado na biologia é fácil de entender; porque a biologia tem aqui sobretudo um problema de clareza. Há inúmeros organismos com capacidade cognitiva pequena e isso exclui que se compreenda a adaptação ao ambiente como limite de cognição, e isto vale neste caso tanto para sistemas psíquicos quanto sociais, que produz apenas a dependência da vida em si, mas adicionalmente também a toda a abertura , uma incontestável necessidade de "requisite variety" (variedade de requisitos) (Ashby).
} 
Comunicação é, portanto, acoplada apenas à consciência e a mais nenhum outro conteúdo do ambiente. Todos os outros eventos do ambiente podem surtir apenas efeitos destrutivos. A consciência está ligada naturalmente ao ambiente mais amplo via seus próprios acoplamentos estruturais, primeiramente através do cérebro, logo em seguida por meio de todas as condições da vida orgânica; mas esses acoplamentos jamais atingem diretamente a comunicação, eles não contribuem com nenhuma participação problemática ou de difícil entendimento. Seu não funcionamento pode apenas interromper o processo comunicativo ou eventualmente terminá-lo, mas não pode jamais levar a perturbações neste processo comunicativo, as quais podem por meio de outros processos comunicativos internos, portanto autopoieticamente, ser remediadas ou transformadas em formas menos irritantes. De qualquer modo, porque a comunicação política é também comunicação e um processar de autopoiése, não podemos esperar nada de diferente neste caso. Quando um sistema político se diferencia rumo à própria autopoiése, é necessário, conseqüentemente, levar em conta uma maneira própria de estruturas, que tornem possível quase todos os conteúdos de comunicação socialmente possíveis e apenas em poucas situações uma sensibilidade específica se desenvolva. Sem a evolução de tais acoplamentos, a diferenciação e o fechamento operacional de um sistema político não teria sido possível. A tarefa seria, portanto, aquela de descobrir o que são os acoplamentos estruturais.

(//375) II

Se a sociedade pode ser acoplada com seu ambiente apenas via consciência, então isso vale também para o sistema político da sociedade. A seleção apurada pode, neste respeito, relacionar-se apenas a pessoas, cuja consciência conta, assim como ao mesmo tempo não conta, para a política. Nem todo mundo é um político. Esta percepção não surpreenderá a ninguém. Não obstante, vale estender alguns comentários que provêm do princípio teóricosistêmico.

Primeiramente: nenhum sistema pode dispor de seus acoplamentos estruturais. Eles ficam invisíveis para o sistema, pois não podem contribuir com suas operações. Isto se aplica também à consciência de políticos. Como consciência, ela não tem nenhuma relevância política. O sistema político também não pode determinar estados de consciência ou exigir 
seletivamente (e também não em casos selecionados). Ele (o sistema) está limitado à seleção de pessoas.

O conceito de "pessoa" aqui deve (e isso inteiramente no sentido de uma antiga tradição) designar uma unidade referenciável na comunicação ${ }^{120}$, e portanto alguma coisa que apenas na comunicação e para a comunicação exista. Comunicação pode funcionar apenas se for diferenciável quem divulga alguma coisa de quem está tomando parte no entendimento de maneira passiva. É necessário um nome para se travar relações comunicativas com pessoas, eventualmente também uma imagem reconhecível, não porém uma decifração de processos orgânicos ou psíquicos dentro da pessoa. É necessário ser capaz de pressupor que sistemas correspondentes possam dominar sua própria complexidade, mas isto não é possível nem necessário, ainda que seja razoável que essa complexidade operacional de um sistema do ambiente se reproduza internamente em um sistema comunicativo. Apenas sob essa pressuposição de indiferença operacional é possível uma comunicação com pessoas e sobre pessoas. Apenas sob esse pressuposto é imaginável uma seleção de pessoas para cargos políticos ou para reputação política.

Ao mesmo tempo, as pessoas são (//376) perceptíveis e reconhecíveis como recortes especiais de seu ambiente, a saber, recortes de alto prestígio, e isto por, outro lado, pode novamente ser pressuposto e considerado na comunicação.

Aqui a perceptibilidade também é garantida no sistema que percebe, e isto independentemente de quais processos internos (físico, químico, orgânico, psíquico) ocorram no sistema percebido. Pessoas são interessantes e fascinam pois se pode criar, sobre isso, suposições. Mas os assuntos internos dos outros sistemas não são acessíveis para sistemas psíquicos, tampouco para sistemas sociais. E exatamente esta inacessibilidade é o pressuposto para que as operações dos sistemas acoplados possam ser sincronizadas num tempo comum.

Mas isto são apenas condições secundárias e, mais aproximadamente, evidências. Elas não esclarecem ainda como a seleção de pessoas para cargos políticos ocorre, a qual conduz então em efeito para um acoplamento estrutural (em sistemas corrigíveis) de poucos sistemas de consciência e comunicações políticas conseqüentes, portanto a um improvável fortalecimento seletivo evolutivo.

${ }^{120}$ Minuciosamente em Luhmann, N. "Die Form: 'Person"” (A forma pessoa). In: Soziale Welt, n. 42, 1991, pp. $166-175$ 
Para uma opção pessoal pela política, a distinção do cargo e da pessoa é uma condição indispensável. Também se pode perguntar o que a biografia de um pessoa e um ser humano na sua socialização deve aos cargos que tinha ocupado, e que cargos podem ser revalorizados pelas pessoas que o ocuparam: distinção entre cargo e pessoa é justamente necessária para tais processos osmóticos. Caso contrário, embora se pudesse atribuir qualidades a pessoas, não se poderia observar distintivamente a carreira das pessoas nos diversos cargos ou os cargos na sucessão de diferentes funcionários. Esse pensamento da separação é para nós tão evidente, que se tem um incômodo de se imaginar como o pessoal da direção é observado, quando esta condição não é dada. Mas, com isso, é indicada apenas uma condição da possibilidade e não o fenômeno já explicado, que a notoriedade pública e a seleção política de pessoas - a meu ver: cada vez mais - se orienta na pessoa. ${ }^{121}$ (//377) E isto vale tanto para a eleição política quanto para a política clientelista e de rede de relações dentro da máquina do poder político. ${ }^{122}$ Ainda precisa ser esclarecida, dito de outra forma, a auto-validação de construções, e não o fato quase ontológico de que algumas pessoas têm sucesso na política e outras não.

Pode-se supor que isto se relaciona com o fato de que políticos precisam tomar decisões, ou que, se se tratar de cargos proeminentes, são acrescentadas a elas mais decisões, onde também pode ter havido sempre restrições precedentes das alternativas. O mistério que, afinal, são as decisões e como elas surgem, é dissolvido através do cálculo sobre pessoas (no seu interior então opaco), ou mais especificamente: transformado em outro mistério mais facilmente palpável e que apareça melhor na imprensa e na TV. ${ }^{123}$ Além disso, também isso é um paradoxo desfeito, a política, a qual destaca pessoas, pode recorrer a preferências e motivos não políticos. ${ }^{124}$ Correspondentemente, a política é sensível ao noticiário sobre

\footnotetext{
${ }^{121}$ Isto foi no tempo das primeiras televisões, portanto um tema das décadas de 50 e 60 . Para mais veja por exemplo Lucian W. Pye, "Politics, Personality and Nation Building", New Haven, 1962; Georges Bourdieau, "Refléxions sur la personnalisatión du pouvoir". In: Res Publica 51 (1963), pp. 127-139; Léo Hamon/Albert Mabileau (Org.) "La personnalisatión du pouvoir: Entretien du Dijon 1964", Paris 1964; Gordon J. DiRenzo, "Personality, Power and Politics: A Social Psychological Analysis of the Italian Deputy and His Parliament System”, Notre Dame Ind. 1967. Entretanto isto é uma trivialidade, mas falta à pesquisa fundamentos teóricos.

${ }^{122}$ Sobre a persistência destas ordens altamente personalizadas também sob condições da modernidade veja Günter Roth “ Personal Rulership, Patrimonialism and Empire Building in the New States”. In World Politics 20 (1968), pp. 194 - 206).

123 Para mais veja Niklas Luhmann "Die Paradoxie des Entscheidens" (O paradoxo da decisão), Arquivo de administração, 1993, pp. 287-310.

${ }^{124}$ A respeito disto e sobre as dificuldades no funcionamento do partido para aceitar isto, veja Ulrich Lohmar "Innerparteiliche Demokratie: Einer Untersuchung der Verfassungswirklichkeit politischer Parteien in der Bundesrepublik Deutschland" (Democracia intra-partidária: uma investigação da realidade da constituição dos
} 
comportamentos não político de políticos - seu comportamento no trânsito, e na relação com policiais, a educação de seus filhos, o tratamento que dá a sua esposa.

(//378) Até aqui neste ponto, a individualidade pode apresentar-se compartilhada (originalidade e inconfundibilidade), da qual a televisão cuida automaticamente. A televisão condensa, poder-se-ia dizer, o acoplamento estrutural da participação comunicativa e da perceptibilidade/reconhecibilidade de pessoas e, com isso, o altamente seletivo acoplamento estrutural de sistemas sociais e psíquicos. Mas a atratividade política de uma personalidade repousa especialmente sobre sua habilidade de decisão e de imposição.

Visto mais exatamente do que se trata as decisões, de acordo com concepções comuns $^{125}$, trata-se de uma escolha interna de uma alternativa pré-estabelecida. Com isso, pode-se tratar da escolha dos meios para uma finalidade pré-estabelecida, mas também de escolher algumas conseqüências como finalidade, com a desclassificação de outras conseqüências (daí inevitáveis) como custos ou meios para a finalidade. Mas uma alternativa também é dada quando se trata de fazer alguma coisa definida: deixar de fazer. A forma da alternativa é indispensável para que um comportamento, afinal, possa ser observado e responsabilizado como decisão. Mas: a decisão em si não ocorre jamais na alternativa. Ela não pode ser encontrada nem de um lado nem de outro desta forma. Portanto não se pode decidir pela decisão - seriam especialmente construídas para isso as alternativa de decidir ou de não decidir. E, por isso, o tomador da decisão também não aparece na sua decisão. Ele é um terceiro fator, através da posição da alternativa de um terceiro valor excluído. A estrutura, portanto, reproduz exatamente o problema de cada um dos observadores: que ele tenha que se orientar por uma diferenciação, na qual ele próprio não aparece, ou , em todo caso, sob a condição de invisibilidade de um "unmarked space". Mas, ao mesmo tempo, não há nenhuma observação sem observador nem qualquer decisão sem o tomador de decisão. O tomador de decisão é o terceiro como exclusivamente incluído, como o ausente presente, o mistério não representável da decisão com uma lógica ambivalente: o parasita no exato sentido de Michel Serres. $^{126}$

partidos políticos na República Federativa da Alemanha), Sttutgart, 1963, pág. 104 e seg.. Eu recordo também de comentários admiráveis nos círculos do partido CDU (Cristão), que Rita Süssmuth (chefe do Parlamento) pôde discursar no palanque sem dar a necessária ênfase para qual partido entraria.

${ }_{125}$ Mais no capítulo 4

${ }^{126}$ Le Parasite, Paris , 1980, nas páginas anteriores Frankfurt 1981. 
Quanto mais aparecem alternativas de decisão, (//379) tanto mais tomadores de decisão e mais parasitas afortunados ou azarados se aproveitam da situação, ou se arruínam. "Fortuna" era o termo clássico para isso - um outro mistério. Ultimamente, trata-se do paradoxo, de que é necessário descrever a forma de dois lados da alternativa como unidade, se ela deve apresentar-se como decisão. Habitualmente, este paradoxo é trazido no decorrer do tempo e, com isso, disperso. Antes da decisão, uma decisão é uma outra do que depois de tomada - antes um alternativa aberta e logo depois a decisão encontrada, a qual poderia ter sido tomada de outra forma (se se lembra dela como decisão ou é reconstruída respectivamente como decisão). Mas esta manobra do desdobramento do paradoxo é fácil de enxergar e conduz à pergunta anterior: como pode a mesma decisão ser uma outra em um momento posterior, como pode o mesmo ser algo diferente?

Pelo fato de sabermos que os acoplamentos estruturais não são visíveis ao sistema, o diagnóstico de que eles não podem orientar nenhuma operação no sistema não deve nos surpreender. Pelo contrário: o mistério da decisão confirma que temos ante nossos olhos um ponto de contato para acoplamentos estruturais - nós, os observadores de segunda ordem, podemos observar o que o próprio tomador da decisão não consegue. O mistério encobre o paradoxo e o paradoxo encobre o ponto cego: a não-observabilidade do observador, a nãodecisão do tomador de decisão. O fato de que este problema se torne em geral relevante, especialmente no caso do sistema político, está conectado à função da decisão coletivamente vinculante e ao fato de que o sistema deve se colocar nesta posição em acoplamentos estruturais, os quais podem ser processados e abrangidos internamente apenas como irritações, como questionamentos, dificuldades, criticabilidades, contingências de cada decisão.

Portanto, os tomadores de decisão se instalam parasitariamente no sistema, ocupamno, dominam-no (sem o que aqui pudesse ser considerado no sentido clássico de domínio visível). Eles deixam vestígios, ao menos vestígios das manchas de seus vestígios. ${ }^{127}$

(//380) Sua dramaturgia pode, como no teatro moderno, ser representada, mas então, assim se pode supor que outros parasitas já estão em obra, os quais constroem pessoas ou as desmontam e com isso permanecem invisíveis como tomadores de decisão. O sistema pode adicionar inteiramente decisões às pessoas e substituir as pessoas nos cargos. Fica em grande 
medida flexível: mas sempre apenas sob a pressuposição de que os acoplamentos estruturais podem através disso ser espalhados para a realidade extra-social de sistemas orgânicos e psíquicos de cada uma das pessoas e podem ser adaptados às experiências do sistema consigo próprio.

Então, fica entendido que a capacidade de decisão, de determinação, e de preparo para a ação pertence aos símbolos, com os quais políticos se auto-promovem ou que através de constelações do acaso são elogiados em sua biografia. ${ }^{128}$ Uma outra conseqüência está na alta fragilidade da política em relação às avaliações morais. Justamente porque não se tem nenhum acesso à sua consciência, pode-se, no lugar disso, avaliar moralmente os políticos; e, por isso mesmo, porque se fazem visíveis como tomadores de decisão. Moral é então um esquema de reclassificação da ação que permite conclusões sobre a pessoa, sem que para isso seja indicado solucionar propriamente o mistério da decisão. A moral permanece com isso, porém, como um código de comunicação e, utilizado pela consciência, torna-se em um sentido mais profundo imoral para avaliar moralmente outros ou a si mesmo. ${ }^{129}$

Sob as condições da opinião pública, isto é, da observação de segunda ordem, (//381)e da democracia, isto é, do código governo/oposição, são acrescentadas ambas teorias da moral sem forte coerção concorrentes do século XVII. Trata-se de, na comunicação política gerada na moral, não de "Decência nas Trevas" (Browne, Shaftesbury e muitos), nem da conquista da beleza (Gracián), mas sim da produção da má aparência. Com isso são abstraídos princípios de valores, que permitem qualquer comportamento ser classificado como mal, porque decisões implicam sempre conflitos de valores. As conclusões sobre a pessoa justamente não são mais possíveis, pois tanta maldade não poderia haver também depois do pecado original.

É para se considerar ainda que o sistema, porque diante do espelho da opinião pública operante, é incumbido com substanciais discrepâncias na produção e representação de decisões. Dessa maneira, cada participante pode tentar alcançar um balanço entre risco e

127 "Trace(s) de l'effacement de la trace" (Vestígios do apagamento de seus vestígios) no sentido de consciente do paradoxo de Jaques Derrida, Marges de la Philosophie, Paris , 1972, pág. $76 \mathrm{f}$.

${ }^{128}$ Para mais Murray, Edelman 'The simbolic uses of politics, Urbana, Ill, 1964, pp. 76 e seguintes. Seria ainda para adicionar que com isso nem "Valor" no sentido antigo das aristocracias é considerado, nem "Carisma" no sentido de uma incumbência mais alta que se torne manifesta na pessoa, porém mais um tipo de habilidade, que é adaptada às condições de trabalho burocráticas e cujas desvantagens pode compensar.

129 "Imoral", em todo caso sob os requisitos da caritas, os dogmas no sentido religioso. Costumeiramente um ponto de vista antigo. Com Thomas Brone, Religio Médici (1643), cit, de acordo com a edição da Everyman's Library, Londres, 1965, pág. 72, lê-se sob o título "Charity": "No man can justly censure or condemn another, 
segurança. E, finalmente, um efeito de fortalecimento de figuras públicas repousa na associação de pessoa e decisão, que reage sobre a forma própria da carreira política e torna difícil para as gerações posteriores quebrar a barreira do som da notoriedade.

Sobretudo, porém, é para se contar com relações circulares, com “interpenetrações” de processos de sistemas psíquicos e sociais, com os quais os sistemas psíquicos se adaptam ao que deles se tornou em pessoas, com as quais se conta. A capacidade de conseguir estimar o comportamento futuro das pessoas torna-se com isso um importante recurso da política, e também a este comportamento serve de base uma forma de intuição, a qual não se deixa mais racionalizar, porque tem que ultrapassar inobservabilidades e se transformar em decisões. As operações de preparação e manutenção de decisões pessoais auto seletivas e extra-seletivas certamente não podem mais ser registradas sob o conceito de sabedoria; mas elas representam como que o decidir no decidir: como decisão sobre premissas de outras decisões no limite do sistema, junto ao qual um ambiente externo descontrolado influencia irritando os acoplamentos estruturais.

(//382) III

O acoplamento estrutural consciência/comunicação diz respeito ao ambiente externo da sociedade. Mas também no interior da sociedade, os sistemas funcionais, sob a condição do fechamento operacional de sua autopoiése, estão referidos a acoplamentos estruturais. E aqui se confirma também que os acoplamentos estruturais precisam ser modelados de forma altamente seletiva, a fim de, através disso, desenvolver a liberdade do sistema associado e poder construir sua própria complexidade. Isso significa também que nem todos os acoplamentos estruturais uniformes se desenvolvem entre todos os sistemas funcionais, e que determinadas conexões sistêmicas são as mais significativas, o que quer dizer: podem atuar de modo mais irritante do que outras.

Acoplamentos estruturais elaborados e diferenciados pressupõem antecipadamente diferenciações funcionais. Na Idade Média, pôde-se distinguir nesta posição somente o conceito de competência: potestas para a política (legítima), iurisdictio para justiça e dominium para economia para com os rendimentos da propriedade fundiária. Dessa maneira, poder-se-ia distinguir campos de atividade e seus problemas específicos, por exemplo,

because indeed no man truly knows another". E, logo em seguida: "Further, no man can judge another, because 
dominium como o problema de que modo uma propriedade organizada pelo direito feudal poderia servir como garantia de crédito, ou o iurisdictio como o problema de definir sob quais condições essa competência, como lei proeminente, poderia ser utilizada como justificativa para a ilegalidade. A conexão dessas competências se auto-evidencia, uma não poderia ser ativada sem a outra. Com a transição para a diferenciação funcional era necessário ser reformulado o problema. Ele aparece agora como um problema da referência, embasamento e irritação mútuos. Em função disso, reagimos na teoria com o conceito de acoplamentos estruturais.

Sobre o acoplamento do sistema político com o sistema de meios de comunicação de massa já tínhamos mencionado pois que ele seria necessário para o esclarecimento do conceito de opinião pública. Este acoplamento dá à política a possibilidade de se estabelecer no plano de observador de segunda ordem. Aqui, podemos ficar com esta indicação. Um outro caso importante é a relação entre o sistema político e o sistema econômico. Para o qual devemos nos voltar agora.

(//383) Seria preciso insistir, sobretudo, que a adaptação da economia ao medium dinheiro concedeu à política as maiores liberdades. Sob a condição da utilização "comum" econômica-política da propriedade, o sistema político tinha pouca margem de movimento e podia, sobretudo, obter poucas possibilidade de centralização. A propriedade não se deixa centralizar, e as possibilidades de comunicação do poder sobre grandes distâncias permaneceram sempre incertas. Logo que a economia monetária começou a se desenvolver foram deixadas também as mais amplas liberdades para o sistema político - inicialmente na época dos assim chamados tiranos, portanto no século VI a.C., simplesmente mediante controle da própria moeda ${ }^{130}$; e a seguir do desenvolvimento de uma dinâmica própria da economia na forma de pagamentos em dinheiro - sejam tributos, sejam impostos que são extraídos da economia para uma utilização sob condições políticas. Com relação a isso é preciso levar em consideração que o dinheiro é um medium que pode ser empregado apenas como forma de pagamento, portanto na economia. Desde o primeiro pagamento, ainda condicionado politicamente, com dinheiro público (que por sua vez foi assumido apenas porque o dinheiro podia ser reutilizado na economia) o emprego do dinheiro subtrai-se ao

\footnotetext{
no man knows himself".

${ }^{130}$ Para mais: Peter N. Ure "The Origin of Tyranny”, Cambridge, England, 1922.
} 
controle político. ${ }^{131} \mathrm{O}$ emprego do dinheiro permanece sempre dependente dos preços que estão em jogo no mundo da economia. O sistema político possui, como proprietário de dinheiro, portanto na economia, a mesma posição que têm outros proprietários de dinheiro, mas ele pode utilizar a liberdade de, como qualquer proprietário, gastar dinheiro de acordo com finalidades auto-determinadas. Isto não se altera quando o sistema político incorpora novas fontes de dinheiro, portanto reivindica créditos ou lança mão da possibilidade de emissão de moeda. O modo de emprego interno à economia mostra-se então na reação da economia como uma super-exigência do mercado financeiro com o correspondente aumento dos juros ou como inflação. ${ }^{132}$

(//384) O orçamento público pode ser visto conseqüentemente como uma forma do acoplamento estrutural do sistema político com o sistema econômico e é claramente superior à antiga ordem feudal devido à combinação de graus de liberdade maiores em ambos os lados. Gastos em dinheiro, então, podem ser motivados no escopo do meio político que está à disposição, sem que os contextos econômicos tenham de ser transparentes para a política (depois de levar isto em consideração, cada proprietário também se torna ele mesmo parte do Estado). Ao mesmo tempo, o sistema econômico não é impedido de reagir de modo determinado estruturalmente e de tratar os gastos públicos de dinheiro como irritação.

$\mathrm{Na}$ Idade Média e até o início da época moderna, o dinheiro era necessário principalmente para a condução das guerras. A emissão de moeda estava ligada a uma condição elementar da existência da dominação política. O Exército e a Fazenda determinavam a direção da diferenciação específica da máquina política. ${ }^{133}$ Para isto, apenas o dinheiro contava efetivamente e fluía para o caixa do príncipe. Isto pôde ser obtido em parte mediante coerção direta, através do recolhimento de impostos, e em parte adaptado à economia capitalista que florescia. Conforme as formas de preparação para a guerra e de

\footnotetext{
${ }^{131}$ Pode ser objetado que as subvenções poderiam permanecer ligadas ao montante de seu emprego. Mas mesmo quando esses montantes são considerados e nenhum projeto adicional planejado é financiado, nosso problema é deslocado em apenas um degrau.

${ }^{132}$ Se se avista esta conexão, a produção política de uma inflação suportável pode ser vista como um meio político para evitar ou diminuir os conflitos políticos, mas esta questão permaneceu controversa na literatura. Isto se aplica mais, à cada vez que se torna menos claro, que propriamente as situações político-econômicas para fosse suficiente para Keynes montar suas condições. Para mais Tom Baugartner/Tom R. Burns, "Inflation: The institucionalized Struggle over income distribution". In: Acta Sociológica 23 (1980),pags. 177- 186; Tom R. Burns/Thomas Baugartner/Phillipe Devillé, "Inflation, Politics and Social Change: Institucional and Theoretical Crisis in Contemporary Economy and Society". In International Journal of Comparative Sociology 25 (1984), p. 73-90.

${ }^{133}$ Para mais : Charles Tilly, “Coercion, Capital, and European States”, AD 990-1990, Oxford, 1990.
} 
emissão de moeda, originaram-se pontos de partida muito distintos para aquilo que posteriormente seria aglutinado em uma forma dominante como "Estado".

(//385) Uma primeira incursão sistematizadora neste problema é descrita retrospectivamente como "mercantilismo". ${ }^{134}$ Aqui não se trata mais apenas de fornecimento direto de dinheiro na medida em que se levanta e se recolhe dinheiro. A política, porém, se ajusta ampla e preventivamente para que o dinheiro afinal esteja disponível no país (na esfera da incursão política possível). Deve ser (como dinheiro) conforme a possibilidade, trazido ao país e não mais ser levado novamente. Uma população rica, neste sentido (e quem não teria pensado nos holandeses naquele tempo), vale como o mais importante recurso da racionalidade estatal da "economia política". O progresso repousa na generalização da perspectiva e na forma indireta da incursão política - e com isso, na ampliação do interesse temático da política.

No século XVIII, o interesse na utilização política da moeda parece se deslocar, com concessões progressivas à economia de livre mercado como a melhor garantia de prosperidade, mais para o campo da dívida do Estado como uma forma de aumento da quantidade de dinheiro, e também sob a inclusão de credores externos. Com todas estas medidas expansionistas, entretanto, a dependência da política se continua constituindo da arrecadação tributária real e detalhada, e seu controle direto ou indireto permanece, em contrapartida, como o trilho primário do acoplamento entre política e economia. Pois, nesse vaivém: o financiamento dos gastos estatais tem conseqüências na economia, a qual se adapta à base da própria dinâmica deste sistema, sem que a política possa alterar alguma coisa nisto. Apenas recentemente este acoplamento foi formalizada e mediatizado via impostos, através de uma segunda forma de acoplamento estrutural de política e economia. Sob condição da democracia, com as eleições políticas abertas, pressupõe-se que os resultados da eleição reflitam a situação econômica, ou, mais especificamente, reflitam as transformações na situação econômica de um país. Embora a economia seja um sistema autopoiético, que define suas próprias operações através de suas próprias estruturas, (//386) há instrumentos políticoeconômicos que tornam possível responsabilizar a política pela prosperidade econômica assim

\footnotetext{
${ }^{134}$ Como clássico sempre é válido: Eli F. Heckscher, "Der Mercantilismus", Volume 2, Jena 1932. Para ver mais, Donald C. Coleman, "Revisions in Mercantilism", Londres, 1969, Fritz Blaich, "Die Epoche des Mercantilismus", Wiesbaden, 1973.
} 
como por um agravamento da situação econômica e do poder de compra, que pode ser distribuído aos indivíduos. Aqui, sobretudo calculam novamente: a parcela de imposto e a dívida pública - que até o século XVIII era o principal meio de geração de divisas. Mas também é para se pensar nas diferenciações da obrigatoriedade do imposto da política de subvenção, na promoção do desenvolvimento da tecnologia, na legislação que incentiva investimentos ou que motiva a emigração da indústria, nas garantias de crédito estatais (especialmente no comércio exterior), na intervenção no mercado de trabalho, no aperfeiçoamento da infra-estrutura financiado politicamente, em muitos casos também na política do banco central e em outras coisas mais. Os efeitos isolados de cada uma destas medidas são difíceis de determinar, considerando a autopoiése e a complexidade do sistema econômico, mas sua disponibilidade basta a fim de tornar responsável politicamente a política pelo desenvolvimento negativo ou positivo da economia. E se pressupõe que as eleições políticas são reativas a isto, especialmente em casos onde os problemas econômicos são experimentados na pele (aumento de preços, desemprego, falta de moradia, declínio econômico de determinadas indústrias ou da agricultura).

Esta nova forma de acoplamento estrutural de economia e política soluciona uma longa discussão, que se travou desde a Idade Média, sobre a justificativa do aumento de imposto. A necessidade dos impostos não deve ser derivada durante muito tempo de uma determinada finalidade do Estado, na expectativa de obter, a partir de uma análise de meios e fins, pontos de vista condutores e limites de uma política tributária racional. ${ }^{135}$ A nova variação política (Estado de bem estar social) das "tarefas do Estado", dissolve todos os seus pontos de apoio referenciais em uma racionalidade de meios e fins na relação entre dinheiro e Estado, e em cujo lugar se coloca o entendimento de que há repercussões políticas quando se subtrai muito dinheiro da economia via impostos, porque o sistema econômico reage a isto em uma direção própria. Trata-se não mais apenas da soma (//387) das irritações de cada um dos contribuintes isolados, que precisam levar seu dinheiro ao Fisco, mas sim das conseqüências que isto acarreta ao sistema econômico, por exemplo o aumento de preços, a deterioração da competitividade internacional, a emissão de rendimento de capital ao exterior, etc. ${ }^{136}$ As

135 Veja também Manfred Wachenhausen "Sttatsausgabe und Öffentliches Interesse in den Steuerrrechtfertingungslehren des naturrechtlichen Rationalismus”, Berlim, 1972 (Despesa pública e interesse público no ensino do racionalismo do direito jusnaturalista no Direito Tributário)

${ }^{136} \mathrm{O}$ contraste passado/presente se mostra menos agudo quando se considera, o que evidententemente o processo legislativo já tinha levado em conta, as diferentes consequiências sociais das diferentes maneiras de tributação 
limitações do aumento de imposto não resultam mais, portanto, dos contornos de uma finalidade do Estado ou de fórmulas clássicas de contingenciamento, como o bem coletivo e o interesse público, mas sim das conseqüências econômicas do aumento de impostos.

Atualmente são acrescentadas como seqüência da evolução social mundial, particularmente no sistema funcional da economia, acoplamentos estruturais modernos. Eles resultam do fato de que os mercados financeiros são continuamente globalizados, mas o trabalho e a produção, tanto agora como antes, precisam ser consolidados regionalmente (mesmo quando expressam tendências nitidamente globalizantes nos mercados consumidores, por exemplo automóveis, têxteis e eletrônicos). Isso tem como consequiência que os países concorrem pelo capital internacional, para conseguirem que o capital seja investido em seus respectivos territórios. Em compensação torna-se necessário que em toda política econômica não se perca de vista as qualidades regionais do próprio país (entre outros, custo de salário e demais custos de produção).

Para o controle do panorama do desenvolvimento econômico politicamente relevante, o sistema político cria para si uma rede de dados de orientação altamente agregados, que indicam a expansão ou retração (inclusive o aumento e a diminuição das expansões ou retrações) - por exemplo do Produto Interno Bruto (PIB), do índice de desemprego, do balanço de pagamentos e do desempenho em relação ao exterior e sobretudo da taxa de inflação. É notável que sejam números que não podem ser utilizados pelas empresas nem pelos consumidores em seus orçamentos domésticos e, portanto, (//388) não desempenham nenhum papel em decisões, que podem ser racionais sob critérios econômicos próprios da economia. Os dados da política econômica por sua vez servem assim apenas para o acoplamento estrutural. A política deixa irritar-se por estas informações, sem que seja possível um "domínio" da economia pela política (no sentido estrito de determinação de estado). A vantagem desses dados está sobretudo na sua contínua correção e de seus prognósticos, além disso, no fato de que a política não é fixada por eles, de forma que possa sempre ter suas controvérsias discutidas, o que por conseguinte deve ser feito. Por outro lado a política tem, como política, também sempre a ver com interpretação, quer se trate na

(por exemplo, tributação do luxo, impostos de renda e imposto sobre a propriedade). Para isso veja minuciosamente Johannes Jenetzky, "System, Entwickerung des materiellen Steuerrechts in der wissenschaftlichen Literatur des Kameralismus Von 1680- 1840, dargestellt anhand der gedruckten zeitgenössischen Quellen (Sistema e desenvolvimento do Direito Tributário material na literatura científica do Cameralismo de 1680 - 1840 representado com base nas fontes da literatura contemporânea), Berlim 1978 
economia sobretudo da diferença entre ricos e pobres, na qual os pobres e não os ricos necessitariam de ajuda. A política impede-se desse modo - e por motivos politicamente bem ponderados - de apreender as conseqüências da análise da economia que os dados sugerem.

A "economia de mercado" é realizada, como conceito político, comumente como a manutenção das reservas de uma ordem estrutural (se não a própria constituição da economia) e como corretivos político-sociais. O arcabouço conceitual da teoria dos sistemas - autopoiése e acoplamento estrutural - oferece mais uma alternativa teórica. Uma comparação exata da eficiência de ambas interpretações dificilmente também poderia ser valorizada mediante diferentes graus de elaboração e do conteúdo de experiências decisivas de novas e antigas formas de pensamento. O texto teórico-sistêmico diz, em todo caso, que há um raio de comparação mais amplo, que também pode ser utilizado em outros sistemas funcionais e em suas relações com o ambiente, ergue as bases teóricas da sociedade, enquanto o conceito de economia de mercado carente de regras e socialmente exigente poderia desembocar na representação da política econômica já como a política da sociedade.

IV

Comparado com os acoplamentos estruturais de política e economia, os quais realmente não foram identificados na tradição européia (//389) (embora na tradição européia antiga fora diferenciado de outra maneira distinta da que foi desde o século XVIII), nos chocamos de frente com um conjunto inteiramente outro, se discutimos a relação entre o sistema político e o sistema jurídico e aí procuramos por acoplamentos estruturais. Tanto no âmbito da common law como do direito civil continental [romano], a organização do domínio político-estatal precisou desenvolver-se inteiramente em um cultura jurídica dada e se compor com ela. Daí, conseqüentemente, a moderna história das idéias oferece antes o quadro de uma unidade de política e direito - uma unidade pelo menos normativamente. Naquele tempo, contudo, o conteúdo do sistema jurídico não era determinado politicamente, mas sim marcado pela diferença, quer juristas definissem o desenvolvimento do direito mais como juízes, professores ou conselheiros dos legisladores (pode, daí, ter havido motivos políticos para 
garantir essa diferença). ${ }^{137}$ A tarefa do príncipe, própria e justamente, se tivesse obtido a soberania, era iurisdictio - no geral como legislação, e no caso particular como sentença, e isso também no lado negativo do código de direito: como possibilidade de conceder exceções do direito vigente (dispensas e privilégios), e até mesmo para alterar, como direito, alguma decisão jurídica; o próprio direito em casos de emergência com base em uma prerrogativa de uma posição jurídica superior. Como instância política, o príncipe podia, portanto, agir em ambos os lados do código de direito - assim, como sujeito confirmar para si o que pensa, com imagens falsas ou verdadeiras. Mas a política se encontra apenas no lugar onde o código do direito se torna um paradoxo - na verdade, quando precisa ser afirmado que o direito, por meio do direito ou da ruptura do direito, tem que ser defendido. Na medida em que este problema seja destrinchado por meio do postulado do estado de direito e por meio das regulamentações detalhadas da Constituição, fundem-se também as imagens de ordem jurídica e política de Estado. A legislação é compreendida como um ato da mais alta força política, o direito no sentido de "direito positivo", e a política, em uma ampla extensão, é convertida em direito comprometido e a própria reserva (//390) de questões políticas específicas ("political questions" - Doutrina da Suprema Corte) não permite nenhuma intervenção da política nos direitos vigentes. Com a eliminação de todas as forças intermediárias de acordo com o modelo da Revolução Francesa e da transição para uma relação direta entre os indivíduos (cidadãos) e o Estado, o direito assume exatamente a função de especificar esta relação. Então, é necessário, por fim, ser prevista também uma jurisdição em questões de direito público. A mobilidade da política é restrita agora por meio de dois fatores: a opinião pública e os tribunais. ${ }^{138}$

Por outro lado, mesmo se fosse concedida uma forma de identidade básica, é claro que as operações políticas se diferenciam nitidamente das operações jurídicas e que uma prática, que não consiga produzir esta diferença terminaria em confusão. Mesmo se o direito dos contratos possa ser reconduzido a um consenso político sobre uma lei correspondente, os fechamentos dos contratos e também as decisões judiciais sobre litígios correspondentes não são operações políticas. O mesmo se aplica ao exame jurídico de atos da administração, até

137 Veja R.C. van Caenegem, "Judges, Legislators and Professors": Chapters in "European Legal History", Cambridge England, 1987.

${ }^{138}$ Assim, para o séc. XX. Marcel Gauchet, "La Revolución de pouvoirs, La souveraineté, le peuple et la representation" 1789-1799, Paris, 1995, pp. 35 e seguintes. Veja também Marc-Olivier Padis/Marcel Gauchet, "La Gênese de la democratie", Paris 1996, p. 93 e seguintes. 
mesmo para o exame constitucional de leis. Cada teoria sistêmica que atenta ao sentido e a maneiras de observação (maneiras de diferenciação) de operações precisa aceitar que o sistema político e o sistema jurídico operam separadamente, que são sistemas distintos $-e$ isso mesmo quando a auto-descrição dos sistemas o contradiga. Por isso aqui se coloca também o problema do acoplamento estrutural.

Nosso pressuposto é inicialmente que o acoplamento estrutural do sistema político com o sistema jurídico se desenvolveu como "Estado". A semântica desse conceito encobre essa situação, quando enxerga a quinta-essência da política assim como a do direito na forma de Estado. Mas a falta de rigor da conceituação, sobre a qual discorremos minuciosamente no capítulo 6, já indica que o conceito com isso esteja sobrecarregado.

(//391) Visto funcionalmente, o Estado é uma unidade fictícia, um truque conceitual que pode ser utilizado pela política e pelo direito de maneiras diferentes. Desta maneira, a abrangência do Estado possibilita uma "mudança de direção" das perspectivas, dependendo se o olhar é lançado do sistema político sobre o direito ou do sistema jurídico sobre a política. ${ }^{139}$ E exatamente esta mudança de perspectiva permanece não observada quando o Estado é conceituado como uma unidade político-jurídica.

Entretanto, o Estado não está adequado a uma forma dada qualquer para cumprir essa função de acoplamento estrutural do sistema político e do sistema jurídico. Para isso é necessário talvez um arranjo artístico, de forma que permita ao direito observar do ponto de vista da política e ao mesmo tempo também à política observar do ponto de vista do direito em cada ocorrência de processos sistêmicos internos. Conhecemos esses arranjos pelo nome de "Constituição". A primeira vez que uma organização precisou ser designada por este conceito foi apenas na segunda metade do século XVIII, e isso foi visto certamente como uma inovação histórica e como progresso evolutivo, ${ }^{140}$ então o novo se encontra nas exigências que um mecanismo de acoplamento estrutural deve satisfazer. O resultado esperado é o aumento do grau de liberdade tanto do sistema político quanto do sistema jurídico - contra tudo o que afirme a semântica e a doutrina do Estado -, de maneira que a autopoiése seja possível nos dois lados e possa alcançar uma auto-organização e ao mesmo tempo uma

\footnotetext{
${ }^{139}$ Para mais Niklas Luhmann "Dois lados do Estado de direito,". In "Conflict and Integration - Comparative Law in the World Today: The 40th Anniversary of The Institute of Comparative Law in Japan", Chuo University, 1988, Tokyo, 1989, pp. 493 - 506.

${ }^{140}$ Para ver mas minuciosamente Niklas Luhmann "Estado como progresso evolutivo". In: Rechtshistorisches Journal 9 (1990), pp. 176-220.
} 
canalização (e com isso uma ampliação) da pressão da irritação recíproca do sistema. A determinação futura da situação do sistema vai ceder às respectivas operações do sistema e, ao mesmo tempo, o efeito do fechamento e o da exclusão do mecanismo de acoplamento assegura um "fluxo estrutural" (structural drift) (Maturana), de maneira que depois de muito tempo os sistemas de política e direito se encontrem em boas condições e tenham uma própria história para lembrar, que somente na base do acoplamento possa ser esclarecida.

(//392) Essas exigências explicam os conteúdos normativos, os quais interessam às constituições, portanto, principalmente o arranjo de alguns elementos fundamentais do direito e de uma regulação organizacional das competências de decisão do Estado. ${ }^{141}$ Elas esclarecem sobretudo também a função latente da mitologia da Constituição, sua fase de apogeu, de sua proclamação de uma identidade, a qual está disponível apenas como um amontoado de texto. Dito de outra forma, é necessário ser encoberto que se trata de instituir apenas uma forma que seja legível de duas maneiras e que possa ser manejada de dos dois lados diferentemente, sem que com isso se forme constantemente conflitos políticos insolúveis.

Isso tudo não é fácil de compreender como a realização de um "texto", de uma lei. Trata-se da constituição de um Estado como uma unidade organizada de efeito e de decisão (Herman Heller). O sistema político encontra possibilidades de recorrer ao direito como instrumento de consecução de objetivos políticos e utiliza para isso as formas e canais de comunicação previstas na organização do Estado. O sistema jurídico pode observar o sistema político sob o código legítimo/ilegítimo, também se o próprio Estado possibilitar isto na forma de tribunais estatais organizados e juízes como funcionários do Estado. No Estado encontram-se constantemente, poder-se-ia dizer, a política e o direito - mas de uma maneira que a distinção de cada um dos sistemas não prejudique suas funções nem de seus códigos. Cada comunicação isolada pode reivindicar relevância em ambos os sistemas acoplados, ou seja, são significativos ao mesmo tempo politicamente e juridicamente. Mas se queremos identificar seu sentido, é necessário que se contenha uma malha recursiva que restrinja os pressupostos e as conseqüências; neste aspecto, as malhas recursivas da política e do direito se diferenciam radicalmente. Quando um ato comunicativo não pode observar esta diferença, ou não pode considerá-la, ele provoca apenas confusão.

\footnotetext{
${ }^{141}$ Não deve ser contestado, naturalmente, que também a isso não sejam registrados artigos requeridos - seja para atingir um consenso para suspensão ou para a modificação da Constituição. Isto não prejudica, entretanto, o argumento do texto.
} 
$(/ / 393) \mathrm{V}$

A relação do acoplamento estrutural do sistema político e do sistema científico merece especial atenção - e não somente porque a própria teoria que traz o conceito de acoplamento estrutural é uma teoria científica. Quando a própria ciência descreve com este conceito sua relação com a política, ela formula ao mesmo tempo uma auto-afirmação. Pode ser que esta afirmação já permaneça controversa na própria ciência, e, em todo caso, ela tem que se colocar de acordo com o costume científico normal, de exame interno da própria ciência, que eventualmente pode levar a uma recusa.

A interpretação de que a ciência pudesse produzir conhecimento, que seria utilizado apenas no sistema político, precisa ser afastada se queremos lidar racionalmente, e atualmente mal é defendida. Por outro lado, falta uma concepção de alternativa clara. Se nos mantivermos em interpretações, as quais, entretanto, são comuns em círculos de especialistas (não somente, mas também com relação à política) encontra-se uma clara consciência das diferenças entre sistemas. Isso vale sobretudo ao princípio da terapia sistêmica. ${ }^{142}$ A ciência, o time de conselheiros, a interação entre conselheiros e clientes e finalmente o sistema de clientes são sistemas distintos, cada um com seus respectivos recursos, dinâmica própria, limites próprios e com isso também suas próprias exigências de discrição. Este conceito sugere que se tome o aconselhamento como forma do acoplamento estrutural. Esta interpretação se harmoniza com as mais novas teorias de aconselhamento, as quais não provêm mais da "utilização" de conhecimento prévio sobre objetos, mas sim tratam de uma postura mais aberta e experimental, com a qual construções do objeto e sugestões para suas modificações servem ao mesmo tempo para a terapia e para o diagnóstico, de forma que se prepare, ao mesmo tempo, com a tentativa de realização, outras construções e outras "indicações". O procedimento continua baseado na ciência, mas isto mais no sentido de uma imaginação disciplinada, e é regulado muito mais fortemente (//394) em experiências adquiridas ad hoc com o sistema de clientes, do que em uma mera transferência de conhecimento acadêmico. Isso se ajusta exatamente ao conceito aqui apresentado de

\footnotetext{
142 Veja por exemplo Kurt Ludewig, "Systemische Therapie: Grundlagen klinischer Theorie und Praxis" (Terapia sistêmica: Fundamentos de teoria e prática clínica), Sttutgart, 1992; Rudolf Wimmer (Editores), "Organisationsberatung: Neue Wege und Konzepte" (Consultoria de organização: Novos conceitos e caminhos), Wiesbaden, 1992.
} 
acoplamento estrutural, o qual não descreve a conexão sistêmica como determinação recíproca, nem como uma interação externamente calculável, mas sim meramente como uma irritação mútua.

Apesar disso, este conceito não é plenamente suficiente paras as nossas finalidades, pois presume o aconselhamento como uma interação. Isto exige organização de ambos os lados das organizações (ou eventualmente indivíduos e família, mas que para nosso contexto é sem interesse). Para a representação do acoplamento estrutural entre sistemas funcionais neste caso o sistema político e o sistema de ciência - é necessário então complementar o conceito. Não é preciso excluir que a comunicação desempenhe um papel na forma descrita e, de fato, sobretudo ocorre no nível da administração tratada como planejamentos políticos em consideráveis extensões. Mas será necessário perguntar também: como se pode formular pelo lado da ciência uma teoria de autonomia do sistema político e de suas organizações, a qual serve para esse conceito de aconselhamento.

Pede-se recuperar aqui todo o arsenal conceitual da autopoiése, fechamento operacional, acoplamento estrutural, diferenciação funcional; mas isso nos levaria a repetições desnecessárias. Nos restringimos, por isso, ao conceito de governo. Enquanto este conceito é definido como a preparação de estados objetivados, a ciência pode enxergar sua própria tarefa somente como a de contribuir com conhecimento auxiliar, útil, inútil ou eventualmente prejudicial (embora verdadeiro). Isso não se altera quando se concede autonomia e repasse ao sistema político, quer o sistema assuma ou não, o conhecimento seguro cientificamente; pois quando já for conhecimento verdadeiro, como se deveria ignorar então o que está diante dos olhos. Se, em compensação, define-se o governo como a aspiração a uma diferença, fosse o caso, eventualmente, isso resulta fundamentalmente em uma outra posição inicial. Então, a ciência pode se limitar em descrever a situação e seu suposto futuro teórica e empiricamente e, com isso, produzir uma necessidade de atuação da política.

(//395) A ciência pode, por exemplo, chegar à constatação politicamente incômoda de que as aposentadorias serão impagáveis no próximo século. Esta descrição pode tornar visíveis aspectos da realidade por meio de agregações estatísticas de dados ou por meio de perspectivas teóricas, do contrário, estes aspectos permanecem invisíveis atrás de esquemas convencionais de percepção da realidade e de conceitos do cotidiano. Instruir de maneira responsável outras formas de observações e descrições já é uma tarefa científica extremante 
exigente, e ao mesmo tempo, além disso, ocorre em um contexto normal de investigação e não precisa ser caracterizada como um emprego de modo especial. ${ }^{143}$ Não obstante, ela pode irritar a política. Do "então é isto" cai-se facilmente para a pergunta: "O que podemos fazer, se isto nos desagrada?". Dito de outra forma, isto faz uma considerável diferença para todas as pretensões do governo, de como elas se percebem e de quais outras pretensões ela se quer diferenciar. Pois as metas não são outras que não fórmulas valorizadas de diferenciação. A acessibilidade das metas com custos e efeitos colaterais defensáveis é uma outra questão e o desejo político e as controvérsias políticas que se incorporam, uma terceira. A ciência pode, por outro lado, para esta forma de finalidade, limitar-se, como ciência, à questão "do que isto se diferencia?". E a suposição é a de que a intenção de se ultrapassar isto e esboçar a possibilidade de mudança, precisa atender à forma do aconselhamento.

(//396) VI

Há numerosas outras relações inter-sistêmicas, as quais poderíamos citar aqui, mas nem todas parecem desenvolver formas próprias de acoplamento estrutural. Muitas dessas relações são desenvolvidas via limiares de tematização dentro dos sistemas participantes. Isso vale, por exemplo, para a observação política de assuntos de cada uma das famílias (em oposição ao direito de família e ao auxílio à família no sentido político-social). Isso se aplica sob condições de uma sociedade "secularizada" também para questões de crença religiosa. Aliás, de resto, há também limitações constitucionais das possibilidades de intervenção política, para tais casos similares. Deixamos questões desta natureza de lado aqui, mas ainda precisamos apresentar uma forma até aqui pouco atendida de acoplamento estrutural, a saber o acoplamento estrutural via organização.

Esta forma de acoplamento estrutural parece se oferecer sobretudo às relações da política com outros sistemas funcionais, nos quais precisa ser trabalhada de maneira intensivamente interacional, portanto intensivamente pessoal e de maneira dispendiosa. Isso

143 A reivindicação se distingue quando se compara com a "habilidade de investigação" de muitos institutos semi-políticos, que consistem apenas em obter por meio de "entrevistas de especialistas", conhecimento, que, de qualquer modo, está disponível no meio apropriado, e em preparar material em uma maneira legível para políticos, mas daí, como há de se supor, produzir material não lido. Não raramente, a política toma conhecimento de tais análises e de alguma coisa sobre seus próprios resultados e o desgaste resultante disto, mas aí então são camuflados como "ciência", na maioria das vezes, os próprios desejos políticos. Veja para inúmeros exemplos Gudrun Richter/Martina Stackelbeck, "Beruf unf Familie: Arbeitszeitpolitik für Eltern kleiner Kinder" (Profissão e Família: política de carga horária para pais de crianças pequenas), Köln, 1992. 
vale para o sistema educacional, e, menos gravemente, também para o sistema de saúde portanto para casos, no quais a sociedade precisa não apenas garantir a recepção e a continuidade da comunicação, mas também procura alterar pessoas pela comunicação. Um tal "processamento de pessoas" se realiza na interação entre pessoas presentes. Mas isso não pode permanecer abandonado ao acaso de sua realização, mas sim é organizado quando a necessidade alcança uma determinada ordem de grandeza. Apenas assim podem ser asseguradas formas racionais da composição e da diferenciação dos grupos de casos, assim como sequiências morosas de tratamento; e, somente assim, pode ser garantida uma certa independência dos meios financeiros de cada um e uma precaução generalizada para possibilidades de tratamento.

Compreende-se, visto de maneira histórico-social, que de forma alguma se aprove aqui falta de organização. Até poucos séculos atrás via-se nisso uma tarefa de responsabilidade doméstica, por exemplo, os hospitais públicos da baixa Idade Média, tratavam apenas dos desamparados. Escolas eram um assunto das igrejas ou dos mosteiros, (//397) eventualmente de professores isolados, como empreendedores privados. As primeiras universidades apareceram como associação de estudantes. Tudo isto se situa, no entanto, em um passado distante, e hoje é incontestável a participação do Estado na organização, na preparação de pessoal, no financiamento do instituto da escola e do ensino superior e, no sistema de saúde, é uma realidade quase imprescindível, pelo menos na forma de garantia de um sistema de financiamento e da assistência básica por meio dos hospitais.

Mas, por que "acoplamento estrutural"?

Nos aproximamos de uma resposta para esta pergunta quando lembramos que o sistema social organizado constrói uma forma absolutamente diferente de realização da autopoiése social como sociedade e seu sistema de funções. Organizações se constituem e se reproduzem por meio de decisões, que se identificam recursivamente na rede das próprias decisões do sistema. A disposição de uma organização produz, portanto, um excesso de possibilidades de decisão, na medida em que toda decisão reduz e ao mesmo abre outras possibilidades de como poderá ser definido posteriormente. Isso inclui também premissas, portanto, as vantagens dos procedimentos estruturais para decisões posteriores no processo operativo da autopoiése. Nada pode ser estipulado do exterior por meio de uma decisão e, apesar disto, a organização, por meio de seu ambiente, segue uma irritação constante e um 
fluxo estrutural, que na rede recursiva das próprias operações é reconhecida como restrição auto-selecionada.

Isso torna provável uma elevada interdependência das premissas. Decisões pessoais não podem ser encontradas independentes de decisões de programas. Ordem hierárquica, seqüências de decisões, tramitação oficial, etc. não se deixam estipular de forma independente das tarefas. $\mathrm{Na}$ verdade, as premissas de decisão são desvinculadas entre si e ligadas a objetivos esperados; uma condução racional de uma organização por meio da tomada de uma decisão isolada mal é possível, neste nível. Justamente no exemplo da organização da educação admirava-se o "acoplamento frouxo" e a "anarquia organizada". ${ }^{144}$ A experiência típica indica (//398) uma considerável confusão. Essa análise conduziu a um ceticismo em relação às possibilidades de planejamento e à suposição de uma estabilidade resistente a reformas. Mas esta análise tem para nossas finalidades uma significação muito mais ampla.

Evidentemente os sistemas funcionais podem se instalar nos sistemas de organização justamente graças a este "acoplamento frouxo" - e precisamente vários sistemas funcionais em uma mesma organização. O sistema jurídico, por exemplo, participa decerto de toda organização - até mesmo quando esta organização se refere a um sistema funcional determinado - como um empreendimento produtivo na economia, ou uma escola no sistema educacional ou um partido político. O mesmo vale para o sistema econômico, onde sempre os participantes precisam ser remunerados em dinheiro. Até mesmo quando é dada uma tal orientação primária, outros sistemas funcionais podem ser ocasionalmente envolvidos - como quando um empresário singular impõe nítida e exageradamente seu ponto de vista de "dono da bola", o que atinge o sindicato patronal de maneira desagradável, quando isso se torna público. De modo geral, pode estabelecer-se portanto que toda produção e desenvolvimento das possibilidades de decisão, por meio da organização sob o princípio geral do excedente e da repressão (pelo qual até mesmo o cérebro trabalha), que oferece um espaço de encontro para os mais diferentes sistemas funcionais, sem que a autopoiése do próprio sistema seja com

144 Para ver mais Karl E. Weick, "Educational Organizations as Loosely Couple Systems"(Organizações educacionais como sistemas frouxamente acoplados), in Administrative Science Quarterly 21 (1976) Pp. 1-19; Michael D. Cohen/ James G. March, "Leadership and Ambiguity”(Liderança e ambigüidade), New York, 1974; John Meyer/ Brian Rowan "Institucionalized Organisations: Formal Structure as Myth and Ceremony"(Organizações institucionalizadas: Estruturas formais como mito e cerimônia), in American Journal of Sociology 83 (1977), pp. 340-363. Para um tratamento inicial de temas correspondentes veja também Alvin W. Gouldner, "Reciprocity and Autonomy in Functional Theory"(Recirpocidade e Autonomia na Teoria 
isso limitada. Elas não precisam também se coordenar. Cada uma delas trabalha do seu próprio modo. O que é considerado politicamente seria designado politicamente sempre apenas por meio do sistema político em referência à sua própria rede recursiva. E todos os problemas de integração, todas as restrições mútuas dos graus de liberdade, afetam apenas a organização.

Pode-se dessa maneira explicar bem porque na prática não se deixou manter o conceito desenvolvido na assim chamada campanha cultural, (//399) para limitar a influência estatal sobre o sistema educacional, sobre questões de organização e de pessoas - para regular as normas escolares apenas sobre esse assunto, que na prática não se deixou circuscrever. As premissas de decisão abrangidas com isso não se deixam isolar em sistemas de organização com todos os "acoplamentos frouxos". Deve-se selecionar professor de religião com o critério de verificar se eles também estão aptos e desejam ministrar aulas de ética laica? A disciplina de estudos sociais é para ser ensinada nas aulas da escola mais por filósofos sociais ou por cientistas políticos? A disciplina de sociologia jurídica na faculdade de direito deve ser sempre ligada a um apenso de uma disciplina de dogmática do direito? Decisões de programa são dirigidas e alteradas por decisões pessoais. Ou: deve-se permitir que escolas, como era comum anteriormente, iniciem aulas de latim e, se for o caso, iniciem somente mais tarde as aulas de inglês, embora isso exclua o posterior acesso de egressos de escolas médias ou populares? E se não: tem que se aceitar então que conhecimentos de latim, quando muito, bastam apenas para a identificação de palavras estrangeiras isoladas? Certamente encontra-se temas políticos sob formas de organização, que por meio do prefixo "unido" [Gesamt] são assinalados, com efeitos nítidos sobre o plano de ensino, quando não sobre a qualidade do ensino. A onda que chama atenção da politização dos assuntos escolares e universitários tem suas raízes em suas infra-estruturas organizacionais.

O mesmo vale para o sistema de saúde, aqui sobretudo na consideração financeira. Quando existem muitos pacientes, o Estado se sente obrigado a disponibilizar instituições apropriadas. A insuficiência no atendimento aproxima-se então de um escândalo político. Mas a medicina moderna dispõe de aparelhos altamente especializados. Isso torna a distribuição dos pacientes nos aparelhos e a sobrecarga destes aparelhos um problema de organização, cujas implicações políticas são fáceis de reconhecer. Também outros problemas, como o do 
serviço funerário, o dos nascimentos prematuros ou o das infecções hospitalares, geram um ônus político condicionado na organização. A organização necessária de determinados desempenhos produz também aqui assuntos políticos e com isso interferências políticas não menos importantes, porque a política moderna reage de forma altamente sensível, (//400) se forem visíveis conjuntos de problemas inteiramente particulares que cada um pode encontrar nos seus próprios interesses, problemas que dizem respeito ao corpo e alma, à saúde e chances de carreira de cada um.

As organizações do acoplamento estrutural servem de sistemas funcionais e, em alguns casos mais do que em outros, produzem uma hipertrofia de possibilidades de decisão, que é reduzida mediante a prática de decisão e de sua "auto-organização". Tínhamos falado da absorção da insegurança e da formação de um mundo auto-construído e de um ambiente seguro. ${ }^{145}$ Da operação fundamental do decidir vista aqui, é imprescindível, com isso, um acoplamento frouxo. Decisões são uma em relação à outra, somente premissas restritivas e expansivas, não no sentido clássico de indicações que precisem ser executadas no sentido exato. O modelo taylorista clássico, burocrático e maquinal, que tinha se concentrado em instrução e execução, pode valer em todo caso como caso limite. Enquanto este modelo se realiza de maneira aproximada, isto exclui a utilização de organizações para o acoplamento estrutural de sistemas funcionais, porque as organizações precisam claramente ser agregadas a determinados sistemas funcionais e serem gerenciadas de maneira heterônima. Não por acaso, teorias organizacionais correspondentes também pressupuseram que o mercado, assim como o aparato do alto escalão da organização, reduz amplamente as decisões e se deixam aparecer como órgãos implementados de conversão de conexões externas em ordenamentos internos (que, neste modelo, justifica sua "autoridade"). Tais concepções dificilmente são defendidas atualmente. Ainda assim, pode-se observar o grau de tecnologização de um sistema de organização como uma variável, que, em relação ao "acoplamento frouxo" ou ao "acoplamento firme", permite diferentes manifestações. E com isso torna-se compreensível então que sistemas de organização, para os quais o acoplamento frouxo é especialmente típico e inevitável, sejam apropriados para acoplar seu âmbito de funcionamento à política, portanto atrair para si a atenção política e para dar partida a um "fluxo estrutural" que faz com que os sistemas acoplados depois de algum tempo (//401) se encontrem em situações em que

Evanston Ill, 1959, pp. 241-270. 
parecem como se tivessem surgido por meio de uma coordenação planejada. Há no sistema político, então, um segmento temático de política escolar ou um segmento de política de saúde, no qual seria reagido à própria história corrente e a novos problemas, embora não se discuta que estas atividades políticas por seu lado educam ou curam os pacientes. E exatamente isto deveria ser explicado com ajuda do conceito de acoplamento.

Pode-se imaginar que em tais âmbitos dos acoplamentos estruturais condicionados à organização, aqueles conceitos se adaptam especialmente bem ao que o neocorporativismo sugeriu. Na relação do sistema político e do sistema jurídico eles nunca foram levados seriamente em consideração, nem mesmo é utilizada a possibilidade de o governo ou o parlamento se deixarem elaborar o parecer da corte constitucional federal. Na relação do sistema político e do sistema econômico, o conceito "neocorporativista" de "ação concertada" fracassou, pois aqui ele depende primariamente de outros mecanismos de acoplamento desorganizados (o que naturalmente não depõe contra a audição de organizações de interessados nos programas políticos concretos, os quais sofrem os efeitos econômicos destes programas). Quando se exclui esta área do governo central, ainda sobram, no entanto, muitas possibilidades para utilizar o espaço de decisão nas organizações políticas, assim como a habilidade de comunicação destes sistemas para as finalidades da coordenação combinada.

VII

Toda referência externa que a política constrói a fim de se relacionar em seu ambiente socialmente externo ou socialmente interno, por conseqüência de um plano de ação, é o resultado de tais acoplamentos estruturais, das irritações internas dele resultantes e de processamento de informação. Não é de se surpreender que programas políticos que tentem obter efeitos do ambiente sejam inseridos no escopo da utopia. Uma das mais famosas destas utopias (//402) conhecemos sob o nome de "economia de mercado social". Ela assume, entre outras premissas, que a política pode criar postos de trabalho, embora nestes postos o trabalho só é desempenhado em face do pagamento em dinheiro, e além disso, que a política ainda é responsável pelas condições sociais do trabalho, salários mínimos, seguros, etc.. em equilíbrio com outras medidas da política social. Estamos tão acostumados com este contexto político da

\footnotetext{
${ }^{145}$ Veja mais no Cap. 7.
} 
economia de mercado social e seus efeitos, que é muito difícil reconhecer o utópico nisto. Mas mal se pode duvidar que "a economia de mercado social" não é nenhuma estrutura própria do sistema econômico (pois que firma, que trabalhador, que consumidor, orientariam sua relação com o dinheiro sobre tal conceito), mas sim que se trata de um conceito político, com o qual a política se auto-satisfaz. Perguntamos por isso, em nome de outras análises que poderiam se relacionar a outros âmbitos da política (por exemplo: igualdade de condições no sistema educacional, promoção cultural, etc..): como isto é possível?

A resposta para esta questão está na disponibilidade de ordenações causais. Horizontes causais são, em princípio, tanto pelo lado das causas quanto pelo lado dos efeitos, abertos. Não existem "causas primeiras" que impossibilitem outros retrocessos na análise, nem "efeitos últimos" que não tenham mais nenhum efeito subseqüente. Além disso, cada aumento mínimo do horizonte de tempo que seja levado em consideração multiplica também o cálculo o número das causas simultaneamente necessárias e dos efeitos simultaneamente produzidos. Além disso, é necessário ser considerado que em contextos sociais não apenas os acontecimentos que realmente se realizam mas também tais que não se realizam são vistos como causais; portanto não apenas atos mas também as omissões, pelo menos quando a ação pode ser esperada ou exigida (mas por meio de quem?). O cálculo de "sorte", ou "fortuna", é apenas uma fórmula positiva para a não-ocorrência de acontecimentos que mal produziriam um assunto. Cada cálculo de risco conta com tal causalidade negativa. E, finalmente, somos habituados em incluir também estruturas nos contextos de causas e efeitos - (//403) portanto em ver determinadas regras do direito como conseqüências de decisões, e simultaneamente, como causas para correspondentes mudanças de comportamento. Certas leis de vacinação extinguiram, então, de fato as doenças correspondentes, alguém duvida disso?

Pelo menos, desde as discussões jurídicas sobre o aumento da dívida e desde as discussões de economia fatorial, isto é uma matéria conhecida. Para estes eternos problemas de ordenação causal poderíamos lembrar de autores célebres como Max Weber, Felix Kaufmann ou Fritz Heider. Por meio da maneira de observação predominante da teoria da ação, contudo, é encoberta toda a extensão do problema, pois só se pode falar de ação se o problema, pelo menos para este caso, já estiver solucionado e as causas interessem apenas como motivos e os efeitos apenas como conseqüências previsíveis ou imprevisíveis da 
ação. ${ }^{146}$ Mas, sempre que o discurso for de causalidade, coloca-se anteriormente a todas as afirmações concretas sempre a pergunta: quem determina essa ordenação? Quem é o observador? Por que assim e por que não de outra maneira? ${ }^{147}$

Similar à quantidade, a causalidade também é um medium intelectual, o qual coloca à disposição unidades (em um dos casos, números e no outro, causas e efeitos), sem com isso já especificar em casos particulares o que é calculado assim como o que é ordenado. O medium, na verdade, restringe a disponibilidade de alternativas, pois a disponibilidade total não permitiria nenhuma constituição de forma. Dito de outra maneira, pode ser utilizado demonstrativamente de maneira incorreta. Mas as possibilidades de acoplamento permitidas são, porém, assim tão imensas, que há a utilização do medium apenas nas operações concretas de cálculo assim como da ordenação da informação sobre qual sistema constitui quais formas.

No medium causalidade podem ser formulados "roteiros" de acordo com o modelo geral: (//404) “isto causa aquilo”. A opinião pública acolhe ansiosamente imagens deste tipo. ${ }^{148}$ Que isto deva ocorrer no medium causalidade significa, contudo, que outras causas e outros efeitos não podem ser excluídos através disso. Roteiros ainda não conduzem assim a uma decisão. Eles oferecem apenas um esquema condensado de contingências, no qual se deve discutir, por exemplo, as conseqüências de uma política de imigração (expandida ou fortemente limitada).

Quando a política descreve suas próprias operações como ações, ela pode utilizar por isso o medium da causalidade a fim de operar sua auto-ordenação. Isso se aplica, notadamente, não apenas à representação dos motivos e das consequiências prometidas das decisões, as quais foram de fato encontradas, mas também às reclamações sobre a política e aos desejos e apelos que precisam ser todos assim formulados, como se o que foi exigido pudesse efetivamente ocorrer. Tanto os governantes como também a oposição, e da mesma forma todos aqueles que expressam sua insatisfação com decisões políticas, se servem do medium causalidade. E sempre é necessário, neste contexto, que sejam construídas

\footnotetext{
146 Para a discussão sociológica veja Mathias Heidenescher, "Zurechnung als soziologische Kategorie: Zu Luhmanns Verständnis von Handlung als Systemleistung”(Ordenação como categoria sociológica: para a compreensão de Luhmann de ação como desempenho do sistema) in Zeitschrift zur Soziologie 21 (1992), pp. 440-455

147 Veja Luhmann, N. "Das Risiko der Kausalität" (O risco da causalidade), in: Zeitschrift für Wissenschaftsforschung 9/10 (1995), pp. 107-119; também in: Najib Harabi (Org.), "Kreativität - Wirtschaft Recht" (Criatividade - Economia - Direito), Zürich, 1996, pp. 1-23.

${ }^{148}$ Veja também Cap. 8 parte III
} 
ordenações auto-executáveis, que se destacam dos horizontes abertos do medium, que é selecionado para um acoplamento firme de acordo com o modelo "isso causa aquilo".

Assim, como é necessário calcular corretamente no medium da quantidade, há também nas ordenações causais um teste de validade, que exclui suposições sem sentido. Embora se possa afirmar que a AIDS é atribuída a experiências secretas ou que em se diminuindo o seguro-desemprego os custos da assistência social aumentam, se alguém duvidar de tais conexões, elas precisam ser provadas. Portanto, não é possível dizer que a política possa fingir conquistas ou que tenha que se ocupar de exigências descabidas criadas ao léu. O problema com o "isto causa aquilo" não é tanto, embora isso possa ocorrer, o erro nas suposições causais, mas sim primeiramente, que apenas um pequeno trecho da realidade seja apreendido. Cada alocação do dinheiro tem como conseqüência (//405) que esse dinheiro não fica à disposição para outros fins. As proibições do comércio de drogas geram mercado negro, a criminalidade do fornecimento e descréditos morais, cujos reflexos mal são compreensíveis. Quem exige o fechamento de usinas nucleares precisa preferir não se importar com as conseqüências de escassez de energia ou das diferentes formas de produção de energia.

Quais são as consequiências? Para isso, haveria aqui muito a dizer. Aparentemente, a política cuida, via ordenações causais limitadas, de uma maneira que sempre tenha alguma coisa para fazer - por um lado porque chegam continuamente acentuações mutuamente contraditórias, e por outro, porque permanentemente ocorrem conseqüências inesperadas ou talvez apenas consequiências fracas, com as quais a política terá que lidar no próximo giro da roda da fortuna. Mas sobretudo se pode observar que as limitações imanentes de cada ordenação causal são projetadas no utópico. Parte-se do pressuposto que é bom quando o que é empreendido obtém sucesso. Ou que seria bom se o que fora exigido fosse realizado. Essa inclinação utópica mostra-se em ambos os lados do espectro político, o da negociação e o da reivindicação. É uma forma que o sistema fornece a si mesmo e que é independente dos programas utópicos. É um correlato inevitável da inevitável redução da complexidade causal.

Com essas considerações torna-se claro que a ordenação causal altamente seletiva se relaciona com o fechamento operacional e com os acoplamentos estruturais, e também, ao mesmo tempo, como. O sistema político gera utopias políticas internas e auto-ordenações a fim de formular as irritações, que, por conta dos acoplamentos estruturais sempre ressurgem de maneira nova. A causalidade é um medium inesgotável, que é reproduzido na forma de 
ordenações de uma para outra situação. E sempre resta alguma coisa. Existem bastante provas de atividades bem-sucedidas, e, como um medicamento que não ajuda, pode-se sempre dizer: teria sido bem pior sem ela.

As utopias políticas conduzem justamente intenções e efeitos escolhidos em um escopo com o qual o sistema se assegura de suas boas intenções. Não são mais contraditórias nem formuladas conscientemente como paradoxo em parte alguma.

(//406) A utopia não é mais trazida do exterior para a política. Ela se instala no sistema político e, sob as condições de diferenciação funcional, é a forma com a qual o sistema se auto-explica, que governando pode arranjar o ambiente, sem, no entanto, poder nele operar. 


\section{VII - BIBLIOGRAFIA}

ARAÚJO, C. \& WAIZBORT, L. Sistema e Evolução na Teoria de Luhmann, mais: Luhmann sobre o Sitema Mundial. In: Lua Nova, n 47, 1999, pp.179-200.

BARALDI, C., CORSI, G. \& ESPOSITO, E. Glossar zu Niklas Luhmanns Theorie sozialer Systeme, Frankfurt a.M., Suhrkamp, 1999. (Glosario sobre la Teoría Social de Niklas Luhmann. México D.F., Universidad Iberoamericana, 1996)

BARBOSA, R. M. Descobrindo a geometria fractal. Belo Horizonte, Autêntica, 2002

BERTALANFFY, L.von. Teoria Geral dos Sistemas. Petrópolis, Vozes, 1997.

BLACK, F. Noise. In: Journal of Finance, v. 41, n. 3, 1986, pp. 529-543.

CLEMENTS, J. Os mitos que você deve evitar se quiser administrar corretamente seu dinheiro. São Paulo, Letras\&Lucros, 2003.

COHN, G. As Diferenças Finas: de Simmel a Luhmann. In: Revista Brasileira de Ciências Sociais, Out. 98, vol. 13, nº 38, p. 53-62.

DAMÁSIO, A. O Mistério da Consciência. São Paulo, Cia. das Letras, 2000.

EVANS-PRITCHRARD, E. Os Nuer. São Paulo, Perspectiva, 1978.

FOERSTER, H. von. On Self-organizing Systems and their Environment. Nova York, Pergamon, 1960.

GADE, C. Psicologia do Consumidor e da Propaganda. São Paulo, Editora Pedagógica e Universitária, 1998.

GEERTZ, C. A Interpretação das Culturas. Rio de Janeiro, Zahar, 1978

GODINHO, R. Os diplomatas do Capitólio: A política externa norte-americana e a influência dos grupos de pressão no Congresso dos Estados Unidos. Brasília, Instituto Rio Branco, dissertação de Mestrado em Diplomacia, 2005.

HABERMAS, J. \& LUHMANN, N. Theorie der Gesellschaft oder Sozialtechnologie - Was leistet die Systemforschung? Frankfurt a.M., Suhrkamp, 1971.

LARAIA, R. (org.) Organização Social. Rio de Janeiro, Zahar, 1969

LUHMANN, N. Ilustración Sociológica y otros ensayos. Buenos Aires, Sur, 1973. . Poder. Brasília, UnB, 1975. Liebe als Passion. Zur Codierung von Intimität. Frankfurt a.M., Suhrkamp, 1982. (Amor como paixão: para a codificação da intimidade. Lisboa, Difel, 1991) 
. Soziale Systeme. Grundri $\beta$ einer allgemeinen Theorie. Frankfurt a.M.,

Suhrkamp, 1984. (Social Systems. Stanford, Stanford University, 1995.)

. Introducción a la teoría de sistemas. México D.F., Universidad Iberoamericana, 1986.

. Ecological Communication. Cambridge, Polity, 1989.

. Essays on Self-Reference. New York, Columbia University, 1990.

. Die Wissenchaft der Gesellschaft. Frankfurt a.M., Suhrkamp, 1992. (La Ciencia

de la Sociedad. México D.F., Universidad Iberoamericana, 1996.)

. A improbabilidade da comunicação. Lisboa, Veja, 1993.

- Zwei Quellen der Bürokratisierung in Hochschulen. In: Soziologische

Aufklärung 4; Westdeutscher, Opladen, 1994 [trad. Stefan Fornos Klein ] .

. Das Recht der Gesellschaft. Frankfurt a.M., Suhrkamp, 1995.

. Die Realität der Massenmedien. Frankfurt a.M., Suhrkamp, 1996. (The Reality

of the Mass Media. Stanford, Stanford University, 2000.)

. Niklas Luhmann: A Nova Teoria dos Sistemas. Baeta Neves, C. E. e Barbosa

Samios, E. M. (Org.), Porto Alegre, Ed. da Universidade/UFRGS, 1997.

. Organización y decisión. Autopoiesis, acción y entendimiento comunicativo.

Barcelona, Anthropos, 1997.

. Complejidad y Modernidad. Madrid. Trotta, 1998.

. Observaciones de la Modernidad. Buenos Aires, Paidos, 1998.

. Die Gesellschaft der Gesellschaft. Frankfurt a.M., Suhrkamp, 1998.

. Art as a Social system. Stanford, Stanford University, 2000.

. Die Politik der Gesellschaft. Frankfurt a.M., Suhrkamp, 2002.

LUHMANN, N. \& DE GEORGI, L. Teoría de la sociedad. Guadalajara, Universidad de Guadalajara, 1996.

MANDELBROT, B. Objetos Fractais. Lisboa, Gradiva, 1992.

MARKOWITZ, M. Bancos e banqueiros, empresas e famílias no Brasil. Rio de Janeiro, Museu Nacional, dissertação de Mestrado em Antropologia, 2004.

MATURANA, H. e VARELA, F. Autopoiesis and cognition, Boston, D. Reidel, 1979.

MERRY, U. Coping with Uncertainty: Insights from the New Sciences of Chaos, SelfOrganization, and Complexity. Westport, Praeger, 1995. 
NEVES, M. Entre subintegração e sobreintegração: a cidadania inexistente. In: Dados Revista Brasileira de Ciências Sociais. Vol. 37, n. 2, 1994.

. From the Autopoiesis to the Allopoiesis of Law. In: Journal of Law and Society. Vol. 28, n. 2, 2001.

PARSONS, T. Sociological Theory and Modern Society. Nova York, Free Press, 1967. . The Structure of Social Action. Nova York, Free Press, 1968. . The System of Modern Societies. Nova Jersey, Prentice Hall, 1971. . Social Systems and the Evolution of Action Theory. Nova York, Free Press, 1977.

PIVETTA. M. O Salto quântico da Ciência Brasileira. In: Pesquisa Fapesp, n. 100, jun. 2004.

RADCLIFFE-BROWN, A R. Introdução a sistemas africanos de parentesco e casamento. Lisboa, Gulbenkian, 1974.

RASCH, W. Niklas Luhmann's Modernity: The Paradoxe of Differentiation. Stanford, Stanford University, 2000.

REPÚBLICA FEDERATIVA DO BRASIL. Decreto-lei nº 2.848, de 7 de dezembro de 1940. Código penal.

. Lei Federal $\mathrm{n}^{\circ}$ 9.394, de 20 de dezembro de 1996. Estabelece as diretrizes e bases da educação nacional.

. Lei $n^{\circ} 9.504$, de 30 de setembro de 1997. Estabelece normas para as eleições. . Tribunal Superior Eleitoral. Resolução 21.609, de 9 de março de 2004. Dispõe sobre a arrecadação e a aplicação de recursos nas campanhas eleitorais e sobre a prestação de contas nas eleições municipais de 2004.

SANT'ANNA, A. Propaganda: Teoria - Técnica - Prática. São Paulo, Thomson Learning, 1998.

SERRES, M. Le Parasite. Paris, Grasset, 1980.

SOLOMON, R. O Comportamento do Consumidor. Porto Alegre, Bookman, 2002.

SPENCER-BROWN, G. Laws of form. Londres, Allen \& Unwin, 1969.

STÄELI, U. Financial Noises: Inclusion and the Promise of Meaning. In: Soziale Systeme, ${ }^{\circ}$ 9, caderno 2, pp. 244-256.

STRYDOM, P. Triple contingency. Theoretical problem of the public in communication societies. In: Philosophy and Social Criticism, n. 25, 1999. 
TEJADA, J. L. La intervención médica: uma propuesta sistêmica. In: Revista Eletrónica Del Magíster em Antropologia y Desarollo, nº 10, mayo 2004, http://rehue.csociales.uchile.cl/publicaciones/mad/10/paper05.pdf

TEUBNER, G. \& FEBBRAJO, A. State, law and economy as autopoietic system: regulation and autonomy in a new perspective. European Yearbook in the Sociology of Law. Milão, Giuffre, 1992.

. O Direito como sistema auopoiético. Lisboa, Universitária, 1996. . Direito, Sistema e Policontexturalidade. Piracicaba, Unimep, 2005.

VIVEIROS DE CASTRO, E (org.) Antropologia do parentesco. Estudos ameríndios. Rio de Janeiro, UFRJ, 1995.

VARELA, F. Principles of biological autonomy, Nova York, Elsevier, 1979.

WEBER, M. Ensaios de Sociologia, Rio de Janeiro, Zahar, 1979. . Economia e Sociedade, Brasília, UnB, 2000 . A Ética Protestante e o Espírito do Capitalismo. São Paulo, Cia. das Letras, 2004.

YOVITS, M., JACOBI G. \& GOLDSTEIN G. (Org.), Self Organizing Systems. Washington D. C., Spartan Books, 1962.

ZOLO, D. Autopoiesis: un paradigme conservatore. Roma, Micro Mega, 1986. 